4 nordon 



\section{Samfundsøkonomisk afkast af pelagiske fiskerier i nordøstatlanten}

Max Nielsen, Peder Andersen, Lars Ravensbeck, Frederik Møller Laugesen, Jesper Levring Andersen, Fødevareøkonomisk Institut, Danmark; Daði Már Kristófersson, Universitetet i Island, Island; Siv Reithe, Jon Nilssen, Universitetet i Tromsø, Norge; Hans Ellefsen, Havforskningssinstituttet, Færøerne

TemaNord 2010:573 
Samfundsøkonomisk afkast af pelagiske fiskerier i nordøstatlanten

TemaNord 2010:573

(C) Nordisk Ministerråd, København 2010

ISBN 978-92-893-2120-4

Tryk: Kailow Express ApS

Omslagsfoto: Scanfishphoto, Jógvan H. Gardar

Oplag: 230

Trykt på miljøvenligt papir som opfylder kravene i den nordiske miljøsvanemærkeordning. Publikationen kan bestilles på www.norden.org/order. Flere publikationer på www.norden.org/publikationer

Denne rapport er udgivet med finansiel støtte fra Nordisk Ministerråd. Indholdet i rapporten afspejler dog ikke nødvendigvis Nordisk Ministerråds synspunkter, meninger og holdninger.

Printed in Denmark

Nordisk Ministerråd

Ved Stranden 18

1061 København K

Telefon (+45) 33960200

Fax $(+45) 33960202$
Nordisk Råd

Ved Stranden 18

1061 København K

Telefon $(+45) 33960400$

Fax $(+45) 33111870$

\section{Det nordiske samarbejde}

Det nordiske samarbejde er en af verdens mest omfattende regionale samarbejdsformer. Samarbejdet omfatter Danmark, Finland, Island, Norge og Sverige, samt de selvstyrende områder Færøerne, Grønland og Åland.

Det nordiske samarbejde er både politisk, økonomisk og kulturelt forankret, og er en vigtig medspiller i det europæiske og internationale samarbejde. Det nordiske fællesskab arbejder for et stærkt Norden i et stærkt Europa.

Det nordiske samarbejde ønsker at styrke nordiske og regionale interesser og værdier i en global omverden. Fælles værdier landene imellem er med til at styrke Nordens position som en af verdens mest innovative og konkurrencedygtige regioner. 


\section{Indholdsfortegnelse}

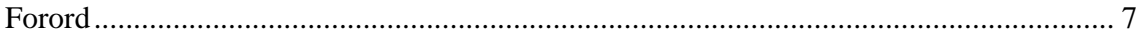

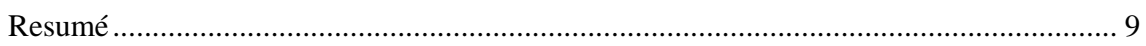

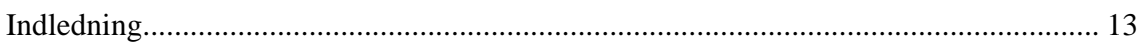

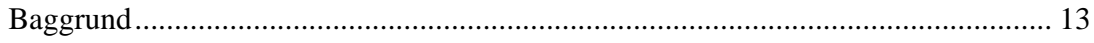

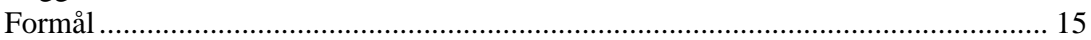

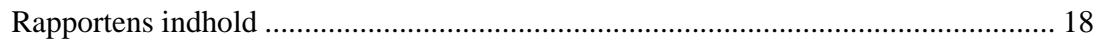

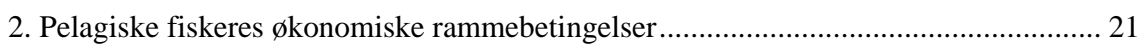

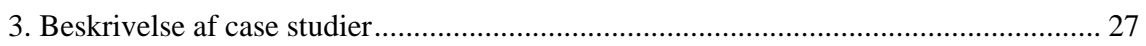

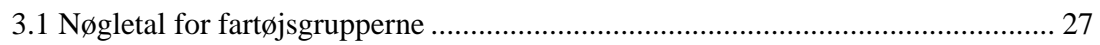

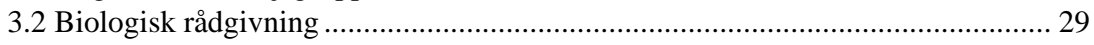

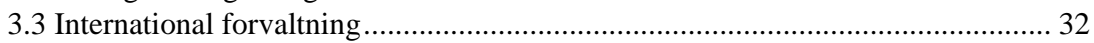

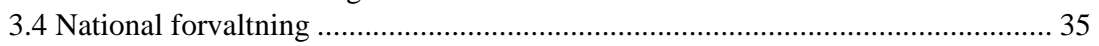

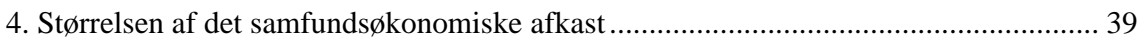

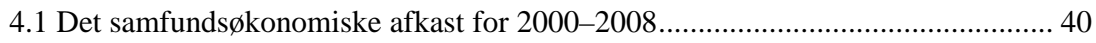

4.2 Det maksimale samfundsøkonomiske afkast.......................................................... 55

4.3 Instrumenter til forøgelse af det samfundsøkonomiske afkast.............................. 66

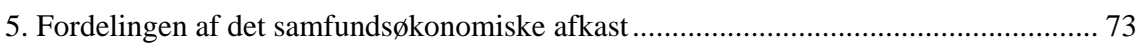

5.1 Fordeling af det samfundsøkonomiske afkast 2000-2008................................ 74

5.2 Fordelingsmæssige konsekvenser af bedre fiskeri-forvaltning ............................. 82

5.3 Instrumenter til omfordeling af det samfundsøko-nomiske afkast......................... 84

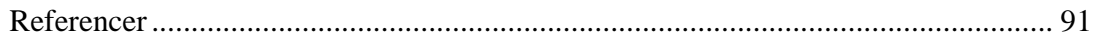

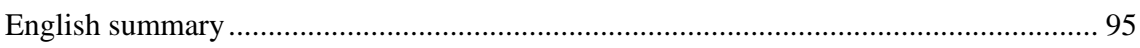

Socio-Economic Return of Pelagic Fisheries in the Northeast Atlantic Ocean .......... 95

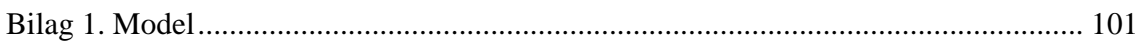

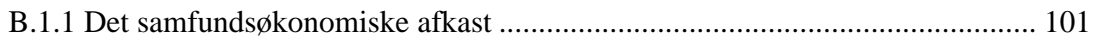

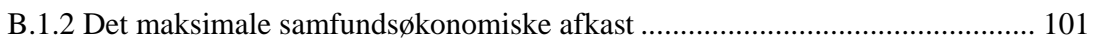

B.1.3 Fordeling af det samfundsøkonomiske afkast................................................ 107

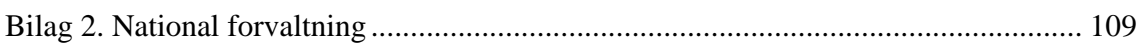

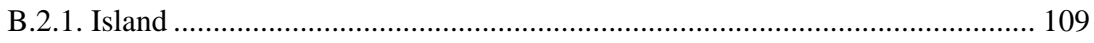

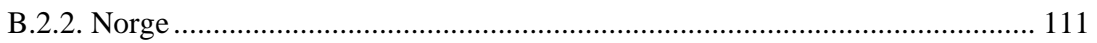

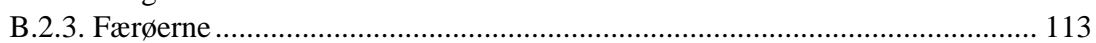

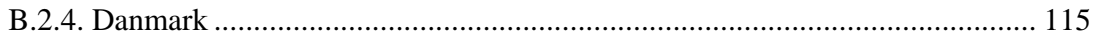

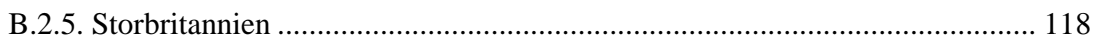

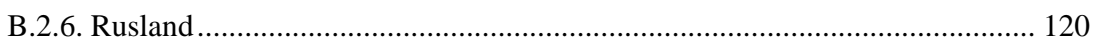





\section{Forord}

„Samfundsøkonomisk afkast af pelagiske fiskerier i Nordøstatlant“ er resultatet af en undersøgelse foretaget med økonomisk støtte fra Nordisk Ministerråd. Initiativtager er Embedsmandskomitéen for Fiskeri, Jordbrug, Levnedsmidler, og Skovbrug, afdeling for Fiskeri og havbrug. Og er en del af det færøske formandskabs program for det nordiske fiskerisamarbejde i 2010. Undersøgelsen efterfølger „Økonomien i de nordiske fiskerier - fokus på ressourcerenten " udgivet af Nordisk Ministerråd i 2006 og strukturen og metoden i denne rapport følger denne undersøgelse. Fokus i denne rapport er på de største fartøjer i pelagiske fiskerier i seks lande som fisker på de samme bestande i Nordøstatlanten, hvor 2006-undersøgelsen fokuserede på fem forskellige typer fiskerier i Norden.

Undersøgelsens resultater som er afrapporteret i nærværende rapport er et fælles ansvar for alle de involverede parter, der indgår i arbejdet. Disse er Fødevareøkonomisk Institut i Danmark, Islands Universitet, Norges Fiskerihøgskola og Havstovan i Færøerne. Parterne har bidraget med data og information fra deres respektive lande, såvel som Fødevareøkonomisk Institut har bidraget med data og information vedr. Storbritannien og Norges Fiskerihøgskola vedr. Rusland. Hver part har endvidere udarbejdet dele af denne rapport.

Rapporten sætter fokus på det samfundsøkonomiske afkast i den del af det pelagiske fiskeri i Nordøstatlanten, der foregår med de største fartøjer. 156 fartøjer indgår. Det samfundsøkonomiske afkast angiver „, det overskud der er tilbage efter aflønning af kapital og arbejdskraft ud over, hvad der opnås i andre erhverv". Det samfundsøkonomiske afkasts størrelse og fordeling, herunder forøgelse og omfordeling, analyseres. Arbejdet er udført som en statistisk baseret økonomisk analyse.

Ansvarlig for arbejdet er faggruppeleder Peder Andersen og koordinator lektor Max Nielsen, begge Fødevareøkonomisk Institut. Fra Fødevareøkonomisk Institut indgår endvidere seniorforsker Jesper Levring Andersen, videnskabelig assistent Lars Ravensbeck og studentermedhjælp Frederik Møller Laugesen, fra Islands Universitet 1. ammenuensis Daði Már Kristófersson, fra Norges Fiskerihøgskola post. doc. Siv Reithe, samt studentermedhjælp Jon Nilssen og fra Havstovan økonom Hans Ellefsen. Elsebeth Vidøe, Fødevareøkonomisk Institut, har forstået redigeringen af rapporten. Der har været afholdt to projektmøder i forbindelse med gennemførelsen af undersøgelsen. 
Rapporten er tænkt som et bidrag i den offentlige debat om det pelagiske fiskeris fremtid i det Nordøstatlantiske område. Målgruppen er politikere, fiskerierhverv og embedsmænd. Rapportens resultater fremlægges på konferencen „Det pelagiske kompleks“, som afholdes i Færøerne den 7-9. september 2010 af Nordisk Ministerråd og det færøske Fiskeriministerium, men undersøgelsen er udført uafhængigt af denne konference.

God læselyst

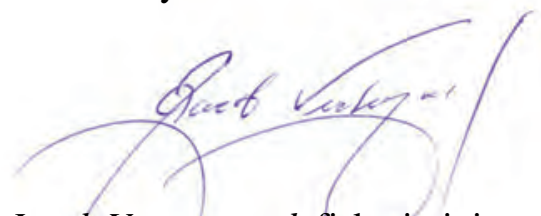

Jacob Vestergaard, fiskeyiminister Nordisk Ministerråd, august 2010. 


\section{Resumé}

„Der er for mange fiskere om at fiske for få fisk“. Dette dækker situationen i mange fiskerier. Konsekvensen er, at fiskerne ikke tjener penge, at fiskerierhvervet ikke bidrager til samfundsøkonomien, at den offentlige sektor har flere udgifter til fiskerierhvervet end indtægter, og at forbrugerne får færre forsyninger af fisk, end de ellers kunne have fået og til en højere pris. Dette er baggrunden for en intensiv fokus på at forbedre fiskeriforvaltningen. Verdensbanken og FAO (2008) vurderer således i rapporten „, The Sunken Billions “, at det samfundsøkonomiske afkast i fiskeriet globalt er negativ. Samfundet har herved flere omkostninger end indtægter fra eksistensen af et fiskerierhverv, hvilket indebærer, at verdens fiskerier ud fra en snæver cost-benefit betragtning burde nedlægges. Over for dette står, at flere undersøgelser viser, at der ved god forvaltning kan opnås maksimale samfundsøkonomiske afkast på 40-50 \% (Nielsen et al 2006; Verdensbanken og FAO 2008).

Analyserne i denne rapport er et bidrag i debatten om, hvor meget samfundet kan opnå økonomisk ved, at der eksisterer fiskerierhverv, som forvaltes ud fra økonomiske målsætninger. Der fokuseres på det pelagiske fiskeri med store fartøjer i Nordøstatlantenten, dvs. fiskeri på de fælles bestande makrel og sild (norsk vårgydende sild og nordsøsild), samt de industrianvendte arter blåhvilling, lodde og tobis. Store fartøjer fra Island, Norge, Færøerne, Danmark, Storbritannien og i mindre omfang Rusland indgår i analysen. Fiskeriet har i en årrække været velforvaltet økonomisk og kan opfattes som en „best practice“. Der anvendes individuelt omsættelige kvoter i Island, Færøerne og Danmark og individuelt ikke-omsættelige kvoter i Norge og Storbritannien, hvor kvoterne følger fartøjer, når de handles, hvorfor systemet minder om individuelt omsættelige kvoter.

Formålet med undersøgelsen er at analysere, hvor meget et velforvaltet og effektivt fiskeri som det pelagiske i Nordøstatlanten bidrager til samfundsøkonomien, samt evt. muligheder for at forøge det samfundsøkonomiske afkast gennem forbedret fiskeriforvaltning. Formålet er endvidere at identificere, hvem udbyttet tilfalder, og hvordan og i hvilket omfang det er muligt at omfordele afkastet fra erhvervet til samfundet. Ønskeligheden af omfordeling vurderes ikke.

Det samfundsøkonomiske afkast angiver „det overskud der er tilbage efter aflønning af kapital og arbejdskraft ud over, hvad der opnås i andre erhverv". Det samfundsøkonomiske afkast måles med og uden fradrag af offentlige udgifter til fiskeriet, herunder til fiskeriforvaltning og tilskud. Det samfundsøkonomiske afkast uden fradrag udgjorde i 2007 1,9 mia. DKK eller gennemsnitligt $32 \%$ i de fem fartøjsgrupper (ekskl. Rusland); højest i den islandske fartøjsgruppe med $43 \%$ og lavest i den danske med $17 \%$. Det 
samfundsøkonomiske afkast efter fradag af disse udgifter udgjorde gennemsnitligt $26 \%$.

De samfundsøkonomiske afkast er svingende i 2000-2008, men udvikler sig nogenlunde ens i landene. Udviklingen følger primært af udsving i priser og bestandsforhold. Afkastet er højest i slutningen af perioden, lavere i starten, og lavest i 2003-2004. Det lave afkast i 2003-2004 skyldes primært lave priser på sild og makrel. Afkastet i de 5 lande er stabilt eller svagt opadgående. Således er det samfundsøkonomiske afkast i Danmark stigende, hvilket skal ses i sammenhæng med at der i 2003-2007 gradvist er indført individuelt omsættelige kvoter.

Det maksimale samfundsøkonomiske afkast beregnes i en bio-økonomisk model under en række antagelser om biologi, økonomi, flådestruktur, fiskerimønster og kapacitetsudnyttelse. Med uændret kapacitetsudnyttelse identificeres det maksimale samfundsøkonomiske afkast, givet at kvotefordelingen mellem landene er uændret, i gennemsnit til $40 \%$ af landingsværdien. Dette svarer til en stigning på $8 \%$;størst i Danmark med $23 \%$ og mindst i Norge hvor afkastet er uændret. Såfremt kvoterne kunne handles frit mellem individuelle fartøjer fra forskellige af de fem lande, svarende til, at de mest effektive fartøjer opkøbte kvoter fra de mindre effektive, opnås det maksimale samfundsøkonomiske afkast til gennemsnitligt $43 \%$ af landingsværdien. Såfremt kapacitetsudnyttelsen kan forøges til 350 dage for islandske fartøjer, 300 for færøske og 250 for de øvrige, opnås tilsvarende maksimale samfundsøkonomiske afkast på hhv. 45 \% og $48 \%$. Ved en uændret kvotefordeling mellem lande svarer dette til en stigning på 14 \%; størst i Storbritannien med 29 \% og mindst i Island afkastet er næsten uændret. Om det er realistisk, at kapacitets udnyttelsen kan forøges, skal ses i sammenhæng både med, at forvaltningen kan begrænse fleksibiliteten, samt med at nogle af fiskerierne, er sæsonbetonede. Det maksimale samfundsøkonomiske afkast vurderes at ligge et sted imellem.

Det høje nuværende afkast afspejler en forholdsvis effektiv økonomisk forvaltning af de analyserede pelagiske fiskerier. Afkastet forekommer at have stor vægt i fiskeripolitikken, andre målsætninger mindre. Beregningen viser endvidere, at der er mulighed for at forøge afkastet gennem forbedret forvaltning, både nationalt og gennem tættere internationalt samarbejde. Afkastet kan forøges mest ved forbedret national forvaltning (8-14 \%) og kun beskedent ved tættere internationalt samarbejde (3\%). Der vurderes ikke at være væsentlige muligheder for at forbedre forvaltningen i de lande, der har individuelt omsættelige kvoter, dvs. Island, Færøerne og Danmark. Dog vurderes afkastet uden yderligere ændringer i forvaltningen at kunne forøges over tid i Danmark og Færøerne, hvor denne forvaltning er forholdsvis ny. I Norge og Storbritannien vurderes fleksibiliteten af forvaltningen at kunne forøges ved at gøre kvoterne fuldt omsættelige, dvs. at de kan omsættes permanent og midlertidigt uden at fartøjer samtidigt skal handles. Det samfundsøkonomiske afkast vurderes også at kunne forøges lidt gennem 
tættere internationalt samarbejde, hvor det tillades individuelle fartøjer fra forskellige lande frit at handle kvoter.

Fordelingen af det samfundsøkonomiske afkast i 2007 mellem ejere af fartøjer og kvoter, mandskab og den offentlige sektor angiver, at offentlige myndigheder gennemsnitligt opnår $11 \%$ af det samfundsøkonomiske afkast. Den offentlige sektors andel er positiv i alle landene ekskl. Danmark; størst på Færøerne med $21 \%$ og mindst i Danmark med -18 \%. I Danmark svarer det til, at skatteindtægterne er mindre end de offentlige udgifter til fiskeriforvaltning mv. fra fartøjs-gruppen.

Mandskabet opnår gennemsnitligt $38 \%$. Mandskabets andel giver sig udslag $\mathrm{i}$, at de har en løn, der er fra $85 \%$ højere end for samme antal arbejdstimer i andre erhverv (Island og Danmark), til næsten fire gange så høj (Storbritannien). En del af forklaringen på den højere aflønning er ulempen ved at være på havet på lange fangstrejser, hvor der kan arbejdes op til 1214 timer i døgnet.

Ejerne får den resterende del af afkastet (gennemsnitligt $52 \%$ ). Størst i Danmark med $74 \%$ og mindst i Norge med $40 \%$. De nuværende ejere kan således have en betydelig indtjening fra fiskeriet. Det behøver imidlertid ikke at være tilfældet, da de nuværende ejere kan have købt kvoter af tidligere ejere. Har de betalt fuld pris kan ejernes andel være givet til tidligere generationer af ejere og trukket ud af fiskerierhvervet. Dette er tilfældet i lande hvor forvaltningen har været gældende i lang tid (Island, Norge, Storbritannien og til dels Færøerne). I Danmark blev den nuværende forvaltning indført i 20032007, og det meste af det afkast vurderes at tilfalde de nuværende ejere.

Forbedres fiskeriforvaltningen, vil ejernes del stige med det samfundsøkonomiske afkast. Om stigningen tilfalder de nuværende eller tidligere ejere afhænger af om forbedringen var forventet. Var den forventet, vil det have givet højere priser på kvoter, og stigningen tilfalder tidligere ejere. Var den overraskende, tilfalder stigningen nuværende ejere. Mandskabet får også del i stigningen, såfremt aflønningsformen er uændret. På lang sigt bliver der færre fartøjer og mindre mandskab om at dele en fast andel af en stigende landingsværdi. Dette giver den del af mandskabet, der forbliver aktive en højere løn.

Med forbedrede forhold for både ejere og mandskab vil stigende afkast give stigende skatteindtægter. Den offentlige sektors andel er dog i flere tilfælde negativ i dårlige år. Dvs. samtidig med at samfundet, jf. fiskeriloven i flere af landene ejer fiskebestandene, er det offentliges nettoudbytte af det velforvaltede pelagiske fiskeri i bedste fald 1/5-del og i gennemsnit 1/10-del af det samfundsøkonomiske afkast. I dårlige år overstiger udgifter til forvaltning mv. skatteindtægterne.

På dette grundlag analyseres muligheden for omfordeling til den offentlige sektor. Såfremt omfordeling er ønskelig, må den nødvendigvis ses i sammenhæng med effektivitet. Årsagen er, at har forvaltningen være gældende i en længere årrække, som i flere af de pelagiske fiskerier, vil omfordeling pålægge erhvervet omkostninger som kan gøre nogles fiskeri urenta- 
belt og tvinge effektive fiskere til at forlade erhvervet. Årsagen er, at det samfundsøkonomiske afkast er trukket ud af fiskerierhvervet, da de nuværende ejere har betalt tidligere ejere for kvoterne. Der er et trade-off mellem størrelse og fordeling af det samfundsøkonomiske afkast; Ønskes en anden fordeling kan afkastet falde.

Fald i det samfundsøkonomiske afkast som følge af omfordeling kan undgås ved at anvende princippet , det samfundsøkonomiske afkast kan alene omfordeles fra dem, der har fået det tildelt“, hvilket begrænser muligheden for omfordeling til situationer hvor det samfundsøkonomiske afkast stiger. Enten som følge af forbedret fiskeriforvaltning, som i det danske pelagiske fiskeri, eller som følge af eksterne forhold som prisstigninger eller forbedringer i fiskebestandene.

Det samfundsøkonomiske afkast kan omfordeles til samfundet gennem brugerbetaling og ekstrabeskatning. Brugerbetaling kan eksempelvis indføres gennem fjernelse af favorable ordninger til fiskeriet som evt. tilskud og fiskerfradrag, gennem opkrævning af omkostninger til fiskeriforvaltning og gennem salg af fiskerirettigheder på auktion. F. eks gennem tilbageholdelse af en lille del af den årlige totalkvote, som efterfølgende sælges på auktion. Beskatningsinstrumenter inkluderer afgifter på landinger, afkast og ejerskab af fiskerirettigheder.

Island er et eksempel på et land, der allerede har afgift på ejernes afkast. Erfaringen er imidlertid at afgiften kun har opkrævet en lille del af det samfundsøkonomiske afkast. Årsagen er, at der har været individuelle kvoter i en lang årrække, hvilket har medført at en stor del af afkastet er trukket med tidligere ejere ud af fiskerierhvervet og derfor ikke beskattes med en afgift på afkastet. Muligheden for yderligere omfordeling uden at påvirke effektiviteten er således begrænset til en situation hvor afkastet stiger som følge af eksempelvis prisstigninger og forbedrede biologiske forhold.

Danmark introducerede i 2003-2007 individuelt omsættelige kvoter og har mulighed for umiddelbart at følge op med omfordeling via brugerbetaling eller beskatning uden, at fartøjerne af den grund bliver urentable. Men som tiden går, og kvoterne handles, bliver mulighederne mindre. Omvendt kan forvaltningen løbende opsiges med et varsel på 8 år, hvilket indebærer at varslet omfordeling altid er mulig.

Færøerne skal revurdere fiskeripolitikken inkl. for pelagisk fiskeri i 2018, hvilket giver mulighed for omfordeling. I Norge og Storbritannien har forvaltningen være gældende i en længere årrække, og muligheden for omfordeling begrænser sig til når det samfundsøkonomiske afkast stiger. Omfordeling kan fx indføres samtidig med, at fleksibiliteten af kvotesystemet forøges ved at muliggøre permanent og midlertidig salg af kvoter uden samtidigt salg af fartøj.

Det understreges, at resultaterne i rapporten bygger på en række beregningsforudsætninger, både hvad angår størrelse og fordeling af det samfundsøkonomiske afkast, samt af det maksimale samfunds-økonomiske afkast. Resultaterne er derfor behæftet med usikkerhed og skal fortolkes med forsigtighed. 


\section{Indledning}

\section{Baggrund}

„Der er for mange fiskere om at fiske for få fisk“. Konsekvensen er, at fiskerne ikke tjener penge, at fiskerierhvervet ikke bidrager til samfundsøkonomien, at den offentlige sektor har flere udgifter til fiskerierhvervet end indtægter, og at forbrugerne får færre forsyninger af fisk, end de ellers kunne have fået og til en højere pris. Dette er en pointe rejst i en lang række sammenhænge over de seneste årtier i forbindelse med analyser og vurderinger af fiskeriets økonomi og er baggrunden for en intensiv fokus verden over på at forvalte fiskeriet på en måde, så det undgås, at der fremover bliver ved at være „for mange fiskere om at fiske for få fisk“.

Praktisk taget alle verdens fiskerier er i dag forvaltet på en eller anden måde, men forvaltningen kan ikke betegnes som en ubetinget succes. Således vurderer FAO (2007), at $72 \%$ af verdens fiskebestande er enten fuldt udnyttede, overudnyttede, nedfiskede eller under genopretning. Samtidig vurderes, at den globale overkapacitet er 30-50 \% (Garcia og Newton 1997). For EU er situationen, at 88 \% af fiskebestandene er fuldt udnyttede, overudnyttede, nedfiskede eller under genopretning, samt at der er en væsentlig overkapacitet (EU-Kommissionen 2010). Det er således ikke lykkedes at reducere antallet af fiskere (fartøjer) tilstrækkeligt, selvom der har været reduktioner de fleste steder, og det ikke er lykkedes at undgå, at der er for få fisk, selvom nogle fiskebestande er på acceptable niveauer. Uden forvaltning ville situationen formentligt have været værre, men det ændrer ikke ved, at forvaltningen langt fra i fuldt omfang har fået løst problemet med , for mange fiskere om for få fisk“.

I de senere år er der kommet fokus på det samfundsøkonomiske afkast af fiskebestandene. Det samfundsøkonomiske afkast angiver „,det overskud der er tilbage efter aflønning af kapital og arbejdskraft ud over, hvad er opnås $i$ andre erhverv "1 . Der er kommet fokus på, i hvilket omfang fiskerierhvervet bidrager til samfundsøkonomien. Verdensbanken og FAO (2008) vurderer således i rapporten „The Sunken Billions“, at ressourcerenten i fiskeriet globalt er negativ. Samfundet har herved flere omkostninger end indtægter fra eksistensen af et fiskerierhverv, hvilket indebærer, at verdens fiskerier ud fra en snæver cost-benefit betragtning burde nedlægges.

I praktisk fiskeriforvaltning er økonomi dog kun én målsætning. Prioriteres målsætninger som regionalpolitiske ønsker om et bestemt bosætningsmønster og tilstedeværelse af eksempelvis kystfiskeri med mindre fartøjer i bestemte områder højt, er konsekvensen, at bidraget fra fiskerierhvervet til samfundsøkonomien nødvendigvis reduceres. Endvidere vurderes, at der 
ved god fiskeriforvaltning kan frembringes en ressourcerente på 40-50 \% af fangstværdien.

Undersøgelsen „Økonomien i de nordiske fiskerier“ identificerede svingende niveauer for ressourcerenter i fem forskellige typer fiskeri (Nielsen et al 2006). I trawlerfiskeri i Island og Færøerne blev ressourcerenten beregnet til hhv. 28 og $20 \%$ af fangstværdien, hvor den i det norske kystfiskeri og det svenske pelagiske fiskeri udgjorde hhv. $-34 \mathrm{og}-20 \%$. Ressourcerenten i det danske muslingefiskeri bestemtes til $44 \%$. Den maksimale ressourcerente blev i de fem nordiske fiskerier bestemt til 6-53 \% (med det norske kystfiskeri og det danske muslingefiskeri som yderpunkter).

Fiskerierhvervet bidrager således positivt til samfundsøkonomien i nogle lande og negativt i andre, samtidig med at Verdensbanken og FAO (2008) vurderer, at erhvervet som gennemsnit bidrager med flere udgifter end indtægter til samfundsøkonomien. Endvidere peger både indeværende undersøgelse samt tidligere (se eksempelvis Nielsen et al 2006 og Verdensbanken og FAO 2008) i retning af, at der ved god forvaltning kan opnås et maksimalt samfundsøkonomiske afkast på op til 40-50 \% af fangstværdien.

Nærværende undersøgelse er et bidrag i debatten om, hvor meget samfundet kan opnå økonomisk ved, at der eksisterer et fiskerierhverv, der samtidigt forvaltes ud fra økonomiske målsætninger. Der fokuseres på det pelagiske fiskeri i den Nordøstlige del af Atlanterhavet, dvs. fiskeri efter makrel og sild, samt de industrianvendte arter blåhvilling ${ }^{2}$, lodde og tobis. Store fartøjer fra Island, Norge, Færøerne, Danmark, Storbritannien og i det omfang, det har været muligt at skaffe data, Rusland, indgår i undersøgelsen.

Årsagen til, at der fokuseres på det pelagiske fiskeri, er, at en række forhold peger i retning af, at målsætningen for forvaltningen af dette fiskeri er det samfundsøkonomiske afkast, samt at forvaltningen er velfungerende og har været det i en årrække. Det pelagiske fiskeri i Nordøstatlanten er en „, best practice“. Der er flere årsager hertil. Der fokuseres på de største kapitalintensive fartøjer, som formentligt også er de mest effektive, såvel som der fiskes på stimefisk med forholdsvist små fangstomkostninger. Endvidere kollapsede den vigtige sildebestand i 1970'erne, og fiskeriet herpå startede først igen op i større skala i starten af 1990'erne. Konsekvensen var, at overkapaciteten, da sildefiskeriet kom i gang igen i 1990'erne, var beskeden. Samtidig har de pelagiske bestande været forvaltet med gode økonomiske instrumenter, og i fire ud af de fem lande har den gode økonomiske forvaltning været gældende i en lang årrække. Således anvender Island, Færøerne og Danmark en potentielt økonomisk velfungerende forvaltning med individuelt omsættelige kvoter; Danmark dog først fra 2003. Norge og Storbritannien har individuelt ikke-omsættelige kvoter, der i Storbritannien administreres via producentorganisationerne. Denne forvaltningsform er ud fra en teoretisk vurdering mindre velfungerende end individuelt omsættelige kvoter, men da systemet i praksis fungerer ved, at kvoterne omsættes som en del af fartøjerne, kapitaliseres kvoteværdien i fartøjsværdien, og systemet kommer til at fungere næsten som et individuelt omsætteligt kvotesystem, om 
end dog lidt mindre fleksibelt. Betingelserne for, at de betragtede pelagiske fartøjer bidrager positivt til samfundsøkonomien, er således gunstige, såvel som betingelserne for at de pelagiske fartøjer bidrager til finansieringen af den offentlige sektor på samme måde som eksempelvis olie- og vandkraftindustrien er gode.

\section{Formål}

Formålet med undersøgelsen er at analysere, hvor meget et velforvaltet og effektivt fiskeri som det pelagiske i den Nordøstlige del af Atlanterhavet bidrager til samfundsøkonomien, samt de evt. muligheder for at forøge det samfundsøkonomiske afkast ved anvendelsen af fiskeriforvaltning, der, både nationalt og gennem internationalt samarbejde, fokuserer på at opnå et større vedvarende økonomisk udbytte af det pelagiske fiskeri. Formålet er endvidere at identificere, hvem udbyttet tilfalder, hvordan fordelingen af udbyttet udvikler sig over tid, og i hvilket omfang og hvordan det er muligt at omfordele udbyttet fra erhvervet til samfundet. Analysen ser alene på, om og hvordan omfordeling kan foregå, og vurderer ikke om, hvorvidt omfordeling rent faktisk er ønskelig, og de forskellige opkrævningsmetoder analyseres ikke nærmere

Der fokuseres på to områder. Det første er størrelsen af det økonomiske udbytte, dvs. hvad det er i dag, og hvad det kan blive i fremtiden, hvis der føres en fiskeripolitik, der alene sigter mod at skabe det maksimale økonomiske udbytte på lang sigt, samt hvordan man opnår et større økonomisk udbytte. Det andet er fordelingen af det økonomiske udbytte mellem kapital, arbejdskraft og samfund; hvordan den er i dag, hvilke instrumenter der kan anvendes i en omfordeling, og hvem der kommer til at bære byrderne heraf.

Det økonomiske udbytte af fiskeriet måles i nærværende rapport som det samfundsøkonomiske afkast som er et mål for den økonomiske effektivitet, men er ikke det samme som overskud. Hvor overskud siger noget om driftsøkonomi, siger det samfundsøkonomiske afkast noget om samfundsøkonomien, dvs. både om kapital- og arbejdskraftaflønning og aflønning til naturressourcen fisk. Ved at identificere det samfundsøkonomiske afkast synliggøres bl.a. evt. ekstraordinær høj arbejdsløn som ikke indgår i overskuddet. Også evt. samfundsøkonomisk afkast der gennem tidligere tiders tildeling af fiskerirettigheder kan være trukket ud af fiskerierhvervet synliggøres. Der sættes fokus på pelagisk fiskeri i den Nordøstlige del af Atlanterhavet i et samfundsøkonomisk perspektiv, som angivet i figur 1.1. 
Figur 1.1 Forøgelse og omfordeling af det samfundsøkonomiske afkast af det pelagiske fiskeri i Nordøstatlanten.

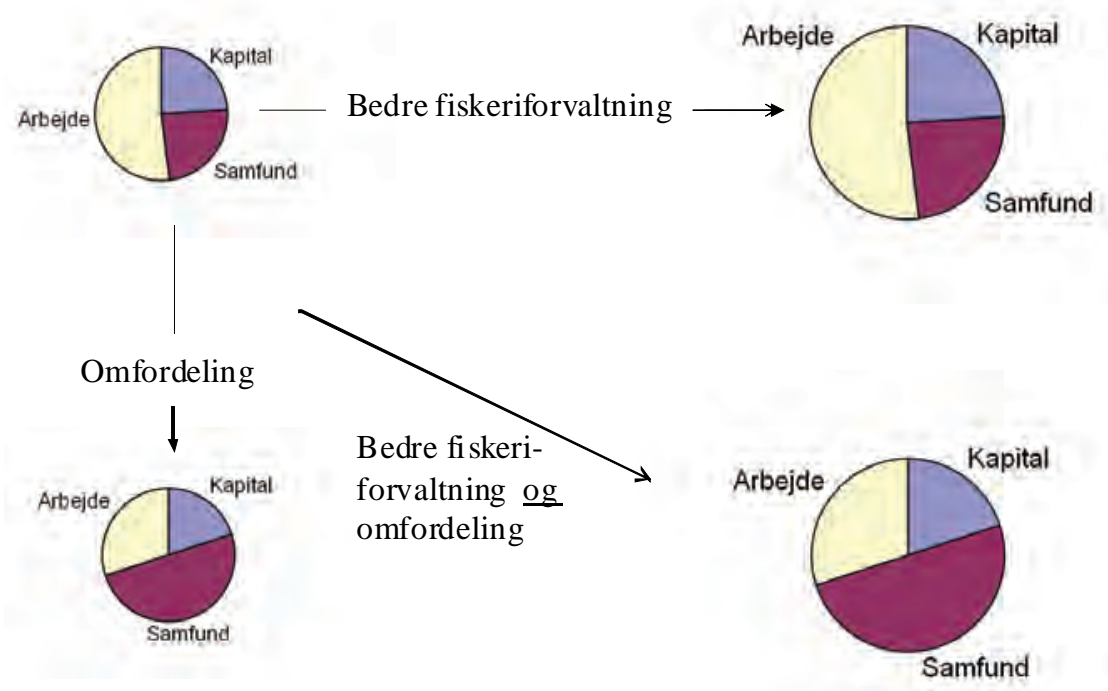

De to emner, der fokuseres på, er dels at bestemme størrelsen af det nuværende samfundsøkonomiske afkast i et velforvaltet fiskeri som det pelagiske i Nordøstatlanten, herunder at vurdere om det samfundsøkonomiske afkast kan forøges ved bedre fiskeriforvaltning nationalt eller gennem tættere internationalt samarbejde, og dels at vurdere, om og hvordan det samfundsøkonomiske afkast kan omfordeles fra kapital og arbejdskraft til samfundet. For at simplificere analysen gennemgås de to emner hver for sig, først størrelsen af det samfundsøkonomiske afkast og derefter fordelingen. I praksis vil der imidlertid være et samspil mellem dem, jf. nederste højre del af figur 1.1. Introduceres omfordeling $\mathrm{fx}$ i form af beskatning af landingsværdien på en uhensigtsmæssig måde og i en situation, hvor fiskeriet er velforvaltet, kan effekten være, at det samfundsøkonomiske afkast falder (lagkagen bliver mindre). Omfordeling vil i en sådan situation medføre, at effektiviteten i erhvervet falder, da fiskerierhvervet bliver pålagt ekstraudgifter, som kan medføre, at for mange fiskere må forlade erhvervet. Som følge heraf vil størrelse og fordeling af det samfundsøkonomiske afkast blive vurderet i sammenhæng.

Det samfundsøkonomiske afkast identificeres i nærværende rapport uden at tage hensyn til, at indenlandsk arbejdskraft kan erstattes af billigere udenlandsk arbejdskraft.

Fokus i rapporten er på det det samfundsøkonomiske afkast, idet dette forekommer at have en væsentlig vægt i forvaltningen af det pelagiske fiskeri i Nordøstatlanten. Målsætningerne i fiskeripolitikken i landene spænder imidlertid bredt og inkluderer ud over det samfundsøkonomiske afkast, driftsøkonomisk overskud, regionalpolitiske forhold som bosætning og beskæftigelse, samt flådepolitik i relation til fx kystfiskeri. Det understreges, at rapporten ikke beskæftiger sig med prioriteringen af disse målsætninger. I rapporten konkluderes alene om og i hvilket omfang, der er et potentiale for at forøge 
det samfundsøkonomiske afkast af det pelagiske fiskeri, herunder om og i givet fald hvordan dette kan opnås gennem forbedret national forvaltning samt gennem større internationalt samarbejde.

I rapporten beregnes endvidere fordelingen af det nuværende samfundsøkonomiske afkast og hvordan fordelingen har udviklet sig over tid, ligesom konsekvenser af omfordeling fra kapital og arbejdskraft til samfundet analyseres. Dette indebærer ikke, at det foreslås, at det samfundsøkonomiske afkast skal omfordeles, men alene, at det vises om, og i hvilket omfang det samfundsøkonomiske afkast kan omfordeles, samt hvilke konsekvenser det konkret kan få. Usynligt samfundsøkonomisk afkast, som er tilfaldet første generations rettighedshaverne, der fik kvoterne foræret, og har solgt deres rettigheder og trukket sig ud af det pelagiske fiskeri, inddrages også i overvejelserne. Årsagen er, at deres del af det samfundsøkonomiske afkast ikke kan omfordeles ved en ændring af fiskeripolitikken, da det er trukket ud af fiskeriet. Dette usynlige samfundsøkonomiske afkast er vigtigt, da det ikke kan omfordeles fra erhvervet til samfundet såfremt princippet „det samfundsøkonomiske afkast kan alene omfordeles fra dem der har fået det tildelt" anvendes.

Der tages udgangspunkt i seks fartøjsgrupper fra seks forskellige lande, der alle fisker på de samme pelagiske bestande i Nordøstatlanten. Dette sker ved at inkludere fartøjsgrupper, der har en række lighedspunkter. I analysen indgår kun store fartøjer, såvel som kun fartøjsgrupper fra lande der vurderes at have god fiskeriforvaltning, der prioriterer det samfundsøkonomiske afkast, indgår. De valgte cases er:

- Danske pelagiske fartøjer over $40 \mathrm{~m}$ reguleret ved individuelt omsættelige kvoter (36 fartøjer)

- Færøske pelagiske fartøjer (trawlere) reguleret ved individuelt omsættelige kvoter (8 fartøjer)

- Norske pelagiske fartøjer (not-fartøjer med tilladelse til blåhvillingtrawling) over 27,5 m reguleret ved individuelt ikke-omsættelige kvoter (45 fartøjer)

- Islandske pelagiske trawlere reguleret ved individuelt omsættelige kvoter (35 fartøjer)

- Britiske pelagiske fartøjer større end $40 \mathrm{~m}$ reguleret gennem tildeling af kvoter til producentorganisationer (32 fartøjer)

- Russiske pelagiske fartøjer reguleret med tildeling af kvoter til rederier (24 fartøjer)

Arbejdet baseres på eksisterende viden om fiskeøkonomiske forvaltningsinstrumenter, på bio-økonomiske modelberegninger samt økonomiske fordelingsanalyser. Der anvendes offentliggjorte informationer, statistikker og undersøgelser om fiskerierne i Nordøstatlanten. Økonomiske data inkluderer regnskabsdata, skattedata samt data om det offentliges udgifter til fiskeriet. Regnskabsdata stammer fra nationale statistikker om økonomien for fartøjs- 
grupperne. Alternativaflønningen for arbejdskraften er kendt fra de nationale statistikbureauers arbejdsmarkedsstatistikker og skattedata er fra de nationale skattemyndigheder. Biologiske data kendes fra det Internationale Havforskningsråd (ICES) samt fra EU-Kommissionens rådgivende tekniske, videnskabelige og økonomiske udvalg for fiskeri (STECF). Hvor der eksisterer relevante erfaringer, og hvor lande uden for Norden er nået længere end de nordiske lande, vil disse erfaringer blive inddraget.

Det understreges, at resultaterne både, hvad angår beregningen af størrelse og fordeling af det samfundsøkonomiske afkast samt af det maksimale samfundsøkonomiske afkast, bygger på en række beregningsforudsætninger. Alle resultater er således behæftet med en betydelig usikkerhed. I beregningen af det faktiske samfundsøkonomiske afkast er usikkerheden i særdeleshed relateret til fastsættelsen af aflønning af arbejdskraft og kapital i alternativ anvendelse. I beregningen af det maksimale samfundsøkonomiske afkast er der yderligere usikkerhed om både biologiske og økonomiske data såvel som om selve beregningsmodellen i en situation, som forudsætter væsentlige strukturelle ændringer i fartøjsgrupperne. Således foretages beregningerne for et gennemsnitsfartøj i hver fartøjsgruppe i hvert af landene. Resultat er en specialisering, hvor kun gennemsnitsfartøjer fra de økonomisk mest effektive lande forbliver aktive. I praksis vil resultater ikke blive, som angivet i scenariet, da forudsætningen om, at alle fartøjer inden for hvert land er et gennemsnitsfartøj, ikke gælder. Derimod vil der ske en specialisering, således at de mest effektive fartøjer fra alle lande vil deltage i fiskeriet. Beregningen af fordelingen af det samfundsøkonomiske afkast baseres på de samme tal, og usikkerheden er derfor også til stede i disse beregninger. Dette indebærer, at resultaterne skal fortolkes med forsigtighed.

\section{Rapportens indhold}

Rapporten indeholder ud over indledningen fire kapitler. I kapitel 2 beskrives fiskernes økonomiske rammebetingelser ud fra en teoretisk indfaldsvinkel. Udgangspunktet er eksisterende viden inden for generel ressource- og fiskeriøkonomi. Fiskeri og fiskeriforvaltning beskrives i et økonomisk perspektiv, og eksisterende viden om økonomiske forvaltningsinstrumenter beskrives.

I kapitel 3 gennemgås strukturen i de udvalgte pelagiske fiskerier, det biologiske grundlag for fiskeriet beskrives, og eksisterende fiskerirettigheder og fiskeriforvaltning gennemgås. Nøgletal for de udvalgte fiskerier diskuteres, og det beskrives, hvem der kan tildeles adgang til erhvervsmæssigt fiskeri, dvs. hvem der kan få rettigheder til fiskeri og efter hvilke principper. Endvidere gennemgås nationale forhold med relation til fiskeriforvaltning, herunder individuelle kvoter, fiskedage, omsættelighed, salg af fiskerirettigheder og ejendomsret til fiskerirettigheder. Endelig gennemgås strukturen i det internationale samarbejde omkring udnyttelsen af de pelagiske bestande. 
I kapitel 4 beregnes størrelsen af det nuværende og maksimale samfundsøkonomiske afkast i de udvalgte fiskerier, og udviklingen heri siden år 2000 analyseres. Det vurderes også, hvordan det samfundsøkonomiske afkast evt. kan forøges gennem nationale forbedringer af forvaltningen samt gennem større internationalt samarbejde.

I kapitel 5 beregnes fordelingen af det nuværende samfundsøkonomiske afkast mellem fiskerierhverv og samfund samt udviklingen i fordelingen over tid. Endelig vurderes de generelle muligheder for at inddrive det samfundsøkonomiske afkast.

I rapporten indgår to bilag. Bilag 1 indeholder en teknisk gennemgang af den bio-økonomiske model, der anvendes til at beregne samfundsøkonomisk afkast, det maksimale samfundsøkonomiske afkast samt fordelingen af det samfundsøkonomiske afkast. I bilag 2 gennemgås den nationale forvaltning af fiskerierne i de seks lande.

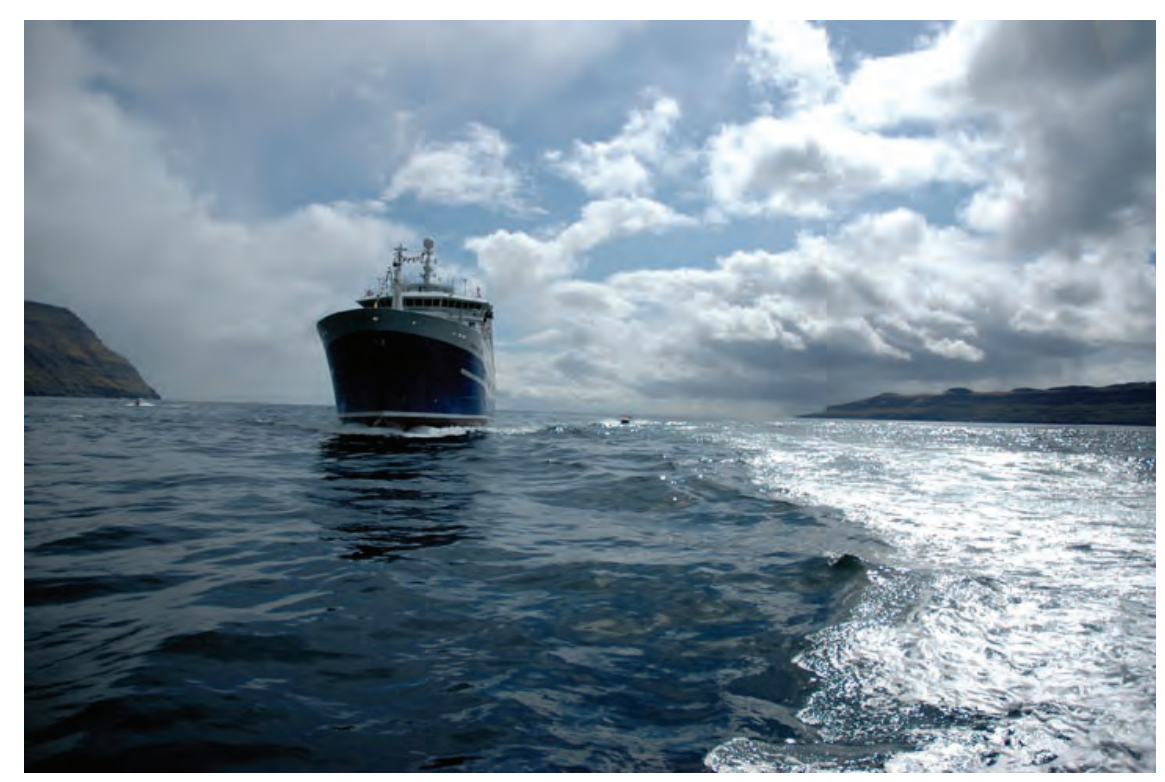





\section{Pelagiske fiskeres økonomiske rammebetingelser}

Fælles ejendomsret, eksterne effekter og manglende prisfastsættelse af eksterne effekter er centrale årsager til, at et frit marked ikke kan fungere samfundsøkonomisk optimalt. Disse forhold karakteriserer udnyttelsen af fiskebestandene, og det er derfor afgørende for at rette op på disse forhold, at der anvendes en hensigtsmæssig fiskeriforvaltning.

Fiskeriet er karakteriseret ved uklare ejendomsretsforhold herunder en uklar fordeling af gevinster ved udnyttelse af fiskebestandene. Årsagen er, at samfundet i princippet ejer fiskebestandene, som udnyttes af mange brugere. Fiskeriet er endvidere karakteriseret ved tilstedeværelsen af såkaldte eksterne effekter dvs. forhold, der ikke direkte indgår i fiskernes økonomiske overvejelser. Eksterne effekter forekommer i form af, at den enkelte fiskers aktivitet påvirker andre fiskeres fangstmuligheder negativt. Dette fører til for mange fiskere til at fiske for få fisk. Konsekvensen er forkert prisfastsættelse på markedet, da priserne på fisk ikke afspejler de manglende fremtidige fangstmuligheder, som overudnyttelse indebærer.

I den fiskeriøkonomiske teori vises, at når der er fri adgang til fiskeriet, tilpasser man sig, så fiskeriindsatsen bliver for stor i forhold til det niveau, der giver den bedste samfundsøkonomiske udnyttelse af bestanden. Fiskebestanden bliver for lille, og der tilvejebringes intet samfundsøkonomisk afkast (Warming 1911, 1931, Gordon 1954 og Clark 1990). Men selv under disse uhensigtsmæssige rammer, kan fiskerne imidlertid sagtens drive et fiskeri med en rentabilitet på niveau med andre erhverv. For samfundet som helhed bindes der imidlertid produktionsfaktorer i fiskeriet i et omfang, så faktoraflønningen til arbejdskraft og kapital i fiskeriet er på niveau med det øvrige samfund, men til gengæld er der ingen aflønning til den sidste produktionsfaktor, nemlig fiskeressourcen. Konsekvensen er, at der bindes for megen arbejdskraft og kapital i fiskeriet. Dette betyder, at der er for mange fiskere til at fiske for få fisk, og de fiskere, der er for mange, kunne bidrage mere til samfundsøkonomien ved at arbejde i andre erhverv. Også den overskydende kapital kunne investeres i andre erhverv og dermed bidrage til et større samfundsøkonomisk udbytte. Konsekvensen er, at fiskeriforvaltning er nødvendig, hvis fiskeriet skal generere et samfundsøkonomisk afkast.

Udviklingen i fiskerisektoren verden over har ændret det frie fiskeri, via oprettelsen af eksklusive økonomiske zoner (200 sømil grænsen) i slutningen af 1970'erne og starten af 1980'erne. Introduktionen af eksklusive økonomiske zoner betød, at kyststater fik kompetence til at forvalte fiskeriet inden for deres nationale zone i modsætning til tidligere, hvor fartøjer af alle nationaliteter havde frit fiskeri uden for kystzonegrænsen. I de efterfølgende 
årtier er der i forskelligt omfang introduceret fiskeriforvaltning med udgangspunkt i, at biologisk forvaltning kan sikre fremtidige fangstmuligheder, og at økonomisk forvaltning kan sikre, at omkostningerne ved at fiske bliver så små som muligt. Dette har ført til, at der i mange lande gradvist er indført strammere fiskeriforvaltning gennem adgangsbegrænsninger fartøjsog kapacitetsbegrænsninger, kvotebegrænsninger, indsatsbegrænsninger, begrænsninger i hvilke områder fiskeri tillades samt begrænsninger i muligheden for at anvende bestemte redskaber.

Effekten af de forskellige typer fiskeriforvaltning er meget forskellig. I nogle få lande er man tæt på en fiskeriforvaltning, der sikrer det maksimalt mulige samfundsmæssige udbytte af fiskeriet. Andre steder er der reelt stadig frit fiskeri.

I det pelagiske fiskeri i den Nordøstlige del af Atlanterhavet har der i flere af landene været en forvaltning, der har skabt positive samfundsøkonomiske afkast af væsentlige størrelser. Dette forudsætter internationalt samarbejde og koordinering, idet det pelagiske fiskeri i Nordøstatlanten er kendetegnet ved, at en lang række lande fisker på de samme bestande. Det forudsætter endvidere anvendelsen af økonomisk effektive fiskeriforvaltningsinstrumenter, jf. boks 2.1.

\section{Boks 2.1. Økonomisk effektive fiskeriforvaltningsinstrumenter}

Fælles ejendomsret, eksterne effekter og manglende prisfastsættelse af eksterne effekter nødvendiggør forvaltning af fiskeriet, såfremt der ønskes et afkast til samfundet af at eje fiskebestande. Hvis det prioriteres at opnå det maksimale samfundsøkonomiske afkast og uden skelen til andre fiskeripolitiske målsætninger som beskæftigelse, regional- og flådepolitik, skal forvaltningen opfylde flere betingelser. Fiskeriet skal være biologisk bæredygtigt, såvel som forvaltningen skal sikre, at fartøjerne kan fiske så effektivt som muligt. Endelig skal forvaltningen være fleksibel og løbende muliggøre tilpasning til ændrede rammebetingelser. Fiskeriet forvaltes ikke hensigtsmæssigt ved at lade de mindst effektive fartøjer fiske, selvom det kan reducere de samlede fangster. Kun et fåtal af de i praksis anvendte forvaltningsinstrumenter lever op til alle de tre betingelser.

Fiskeriforvaltningsinstrumenter kan deles op i fysisk og økonomisk forvaltning. Fysisk forvaltning inkluderer adgangsbegrænsning til fiskeri, totalkvoteregulering, indsatsforvaltning og tekniske bevaringsforanstaltninger som maskestørrelse, mindstemål, lukkede områder og perioder. Økonomisk forvaltning kan være afgifter på landinger og på adgang til fiskeri. Markedsbaseret forvaltning som individuelt omsættelige kvoter er som fysisk forvaltning baseret på totalkvoter, men har de samme indbyggede økonomiske incitamenter til at sikre samfundsøkonomisk afkast som fangstafgifter og er derfor primært et økonomisk forvaltningsinstrument.

Økonomiske forvaltningsinstrumenter kan i teorien sikre opnåelsen af det maksimale samfundsøkonomiske afkast, idet de lever op til ovenstående tre betingelser. Biologisk bæredygtigt fiskeri kan opnås ved individuelt omsættelige kvoter gennem totalkvoten, hvor effektivitet og fleksibilitet opnås ved, at de mest effektive fiskere løbende køber de mindst effektive ud af erhvervet og overtager deres kvote. Ved afgifter opnås både bæredygtigt fiskeri, effektivitet og fleksibilitet ved, at de mindst effektive fiskere som følge af urentabelt fiskeri løbende må forlade erhvervet. 
Forskellen mellem individuelt omsættelige kvoter og afgifter er dels, at bestemmelsen af afgiftsniveauet er behæftet med betydelig usikkerhed, som gør praktisk anvendelse af afgifter til et upræcist forvaltningsinstrument, dels fordelingen af det samfundsøkonomiske afkast, der skabes. Ved afgifter tilfalder afkastet samfundet, hvor det ved individuelt omsættelige kvoter afhænger af, hvordan kvoterne er tildelt. Hvis samfundet sælger kvoterne på auktion, tilfalder hele afkastet samfundet, såfremt kvotemarkedet er velfungerende. Hvis samfundet forærer kvoterne væk, vil det være kvoteindehaverne, og i mange tilfælde også mandskabet, der modtager afkastet. Samfundet får dog del heri via indkomst- og selskabsskatter. I praksis anvendes individuelt omsættelige kvoter i en lang række lande, inkl. i det pelagiske fiskeri i Nordøstatlanten. Afgifter er derimod, så vidt vides, ikke det bærende element i fiskeriforvaltningen noget sted i verden.

Fysisk forvaltning kan også, rigtigt anvendt, forøge det samfundsøkonomiske afkast, men det maksimale samfundsøkonomiske afkast kan ikke opnås ved brug heraf. Årsagen er, at der ikke er tilstrækkelig tilskyndelse til at anvende de nyeste og mest effektive teknologier, der løbende sikrer strukturtilpasning, samt at der kan være omfattende administrative og kontrolmæssige omkostninger knyttet til brugen af detaljeret fysisk forvaltning.

Island introducerede således individuelt omsættelige kvoter i det pelagiske fiskeri allerede i 1978. Norge og Storbritannien har også haft økonomisk effektiv forvaltning i en længere årrække, såvel som Færøerne og Danmark har fået det efterfølgende. Den tidlige introduktion af økonomisk effektiv forvaltning af disse pelagiske fiskerier skal bl.a. ses i sammenhæng med, at pelagiske fiskebestande typisk har samlende adfærd (schooling adfærd). Dette indebærer, at fiskene samles i stimer (hele tiden eller en del af året), og at de derfor er lette at fange, hvorved bestandsstørrelsen bliver mindre vigtig for fangstomkostningerne pr. tons end for andre fiskearter. Dette betyder, at pelagiske fiskearter bliver forholdsvis billige at fange. Samtidig er de dog også lette at nedfiske, og den store norsk vårgydende sildebestand blev nedfisket gennem 60'erne og 70'erne. Der kom først betydende fiskeri på bestanden igen i starten af 1990'erne.

I en situation som i det pelagiske fiskeri i Nordøstatlanten, hvor der genereres et væsentligt samfundsøkonomisk afkast, påkalder fordelingen af dette afkast sig særlig interesse. Flere lande angiver i fiskerilovgivningerne, at fiskebestandene ejes af samfundet, repræsenteret ved den offentlige sektor. Samtidig har landene uddelt eksklusive rettigheder til pelagisk fiskeri i Nordøstatlanten. Men samtidigt indebærer det generelle skattesystem, at både arbejdskraft og kapital beskattes af deres fiskeriaktiviteter og herigennem betaler en del af det samfundsøkonomiske afkast til den offentlige sektor. Omvendt har den offentlige sektor udgifter til fiskeriet i form af tilskud, gennemførsel af fiskeriforvaltning og kontrol, biologiske undersøgelser og rådgivning.

Den effektive forvaltning af de fem pelagiske fiskerier i denne rapport har eksisteret i en årrække, dog bortset fra forvaltningen af det danske fiskeri. Dette indebærer, at tidligere generationer af rettighedshavere har fået en væsentlig andel af det samfundsøkonomiske afkast, idet de enten har fået tildelt fiskerirettigheder gratis (første generations-rettighedshavere) eller har 
købt rettigheder på et tidspunkt, hvor det samfundsøkonomiske afkast var mindre, og prisen på rettigheder derfor lavere end i dag. Når nye generationer af fiskere skal ind i fiskeriet, skal de købe deres rettigheder, enten særskilt eller tilknyttet fartøjerne, og betale de gamle fiskere. Og da forvaltningen af det pelagiske fiskeri har eksisteret i en længere årrække, må der formodes kun at være få aktive fiskere tilbage, der oprindeligt har fået kvoterne tildelt. Muligheden for at opkræve det samfundsøkonomiske afkast fra erhvervet begrænses således af dette, såfremt der kun ønskes opkrævet samfundsøkonomisk afkast fra dem, der rent faktisk har modtaget det, og ikke fra nye rettighedshavere, der allerede har betalt det samfundsøkonomiske afkast én gang til de tidligere rettighedshavere.

Omvendt kan en del af det samfundsøkonomiske afkast opkræves fra arbejdskraften til samfundet, såfremt arbejdskraften har en væsentlig højere aflønning, end hvad der er nødvendigt for at tiltrække arbejdskraft til det pelagiske fiskeri.

Fordelingspolitiske instrumenter til opkrævning af det samfundsøkonomiske afkast er vist i boks 2.2.

\section{Boks 2.2. Fordelingspolitiske instrumenter til opkrcevning af} samfundsøkonomisk afkast fra fiskeriet til samfundet.

Hvis der eksisterer en hensigtsmæssig fiskeriforvaltning, hvor der genereres et samfundsøkonomisk afkast, som ejer af fiskerirettigheder og arbejdskraft (mandskab) opnår en andel af, kan en række fordelingspolitiske instrumenter anvendes til opkrævning af dette afkast til samfundet.

Instrumenter til opkrævning af afkastet til samfundet kan opdeles i brugerbetaling og afgifter. Brugerbetaling inkluderer:

- Salg af fiskerirettigheder/kvoter på auktion

- Opkrævning af omkostninger til fiskeriforvaltning

- Reduktion/fjernelse af favorable ordninger til fiskeriet, herunder tilskud og fiskerfradrag

- Tilbageholdelse af en lille del af den årlige totalkvote, som efter-følgende sælges på auktion

Beskatningsinstrumenter inkluderer afgifter på:

- Landinger

- $\quad$ Ejerskab af fiskerirettigheder

- Salg og leasing af fiskerirettigheder/kvoter

Billedet af hvem, der får andele af det samfundsøkonomisk afkast, er ikke entydigt. Derfor er det heller ikke entydigt klart fra hvem, det kan opkræves. Specielt ikke da det samfundsøkonomiske afkast er vanskelig at beregne præcist, ændrer sig over tid og afhænger af andet end forvaltningen, herunder af delvist eksternt bestemte forhold som rekruttering af fisk og af priser. 
Disse vanskeligheder gør det imidlertid blot mere påkrævet med en fornuftig fiskeriforvaltning suppleret med en fornuftig fordelingspolitik.

Med udgangspunkt i det ovenfor beskrevne grundlag for de pelagiske fiskeres økonomiske rammebetingelser, identificeres og beregnes i de efterfølgende kapitler det samfundsøkonomiske afkasts størrelse og fordeling samt potentialet for forøgelse og omfordeling i de fem udvalgte pelagiske fiskerier i Nordøstatlanten.

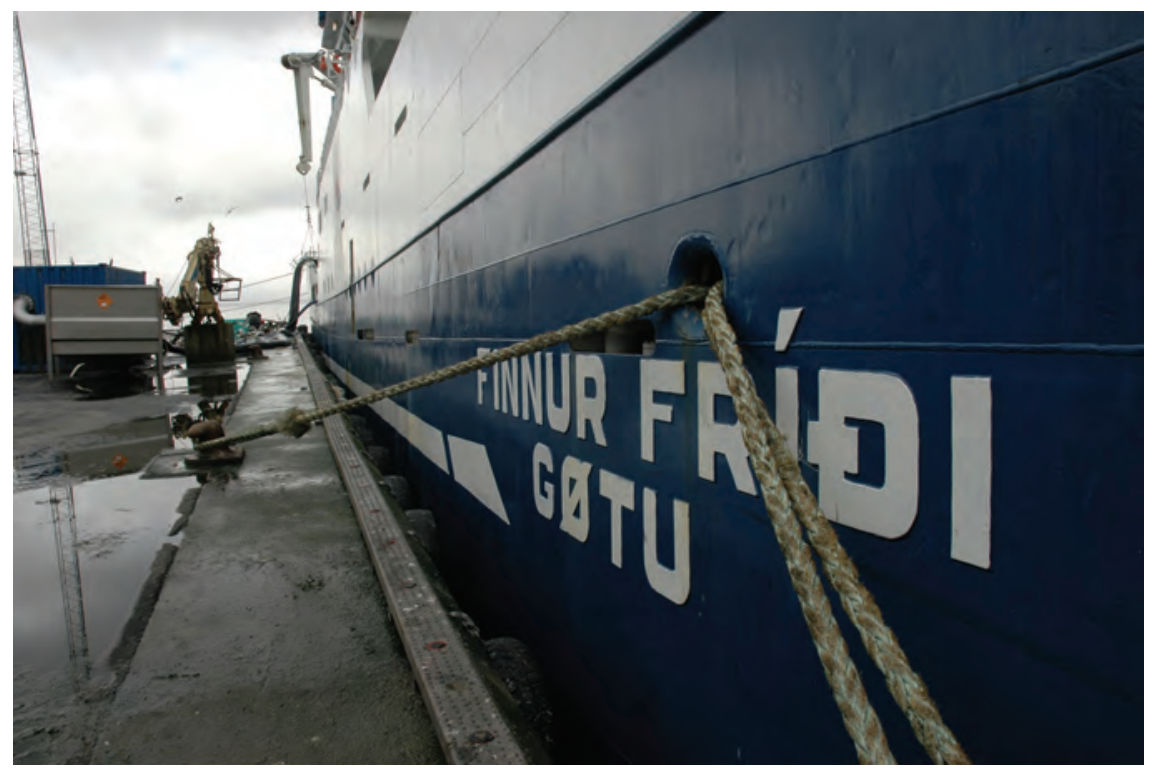





\section{Beskrivelse af case studier}

\subsection{Nøgletal for fartøjsgrupperne}

Nøgletal for de seks fartøjsgrupper er angivet i tabel 3.1 for 2007. Perioden i disse case studier er fra 2000 til 2008.

Tabel 3.1. Nøgletal for de udvalgte fartøjsgrupper, 2007.

\begin{tabular}{|c|c|c|c|c|c|c|}
\hline & Island & Norge & Færøerne & Rusland $^{2}$ & Danmark & $\begin{array}{r}\text { Stor- } \\
\text { britannien }\end{array}$ \\
\hline Beskæftigelse $^{1}$ & 532 & 683 & 198 & 1.560 & 263 & 318 \\
\hline Landingsværdi (mio. DKK) & 1.236 & 2.000 & 562 & 835 & 708 & 1.447 \\
\hline Antal fartøjer & 35 & 45 & 8 & 24 & 36 & 32 \\
\hline Tonnage (gns. BT) & 1.285 & 1.147 & 2.132 & . & 730 & 1.716 \\
\hline Motorkraft (gns. HK) & . & . & 5.940 & 3.500 & 1.166 & 2.919 \\
\hline Forsikringsværdi (gns. Mio. DKK) & 36 & 100 & 112 & 82 & 36 & 86 \\
\hline Antal havdage (gns.) & 320 & 206 & 280 & 300 & 172 & 113 \\
\hline Andel af total landingsværdi (\%) & 18 & 20 & 24 & . & 26 & 21 \\
\hline $\begin{array}{l}\text { Andel af fangst til industri (\% af } \\
\text { værdi) }\end{array}$ & 61 & 22 & 55 & Lav & 33 & 6 \\
\hline
\end{tabular}

Noter:

${ }^{1)}$ Angiver fuldtidsbeskæftigelsen, der for Danmark er beregnet som kendt antal arbejdsdage pr. år, under antagelse af, at en arbejdsdag på havet er 12 timer, men at en normal fuldtidsarbejdsdag er 7,4 timer i 220 dage om året. For de øvrige lande antages det samme, samt at der er en besætning på 12 mand på et fartøj fra UK og Færøerne, 9 mand på et fartøj fra Norge og 6,5 på et fartøj fra Island.

${ }^{2)}$ Nøgletal fra Rusland kendes ikke og er derfor estimeredt på grundlag af den bedste tilgængelige viden. Nøgletallene fra Rusland er derfor behæftet med betydelig usikkerhed, og tolkning af disser skal foretages med varsomhed. Kilder: Landingsstatistik (Statistics Iceland (a), Norges Sildesalgslag, Færøerners Statistiske kontor,Fiskeridirektoratet Danmark og STECF) og Fiskeriregnsskabsstatistik (Statistics Iceland (b) og Eskja 2010, Fiskeridirektoratet i Norge, NOTA 2010, Fødevarøkonomisk Institut og STECF).

De seks case studier er valgt med udgangspunkt i tilgængeligheden af data og med henblik på at repræsentere fiskeriet efter de samme arter i flest mulige lande.

Som det ses i tabel 3.1, er beskæftigelsen, målt som fuldtidsansatte, størst i det islandske og norske fiskeri. I Storbritannien og Danmark ligger det på omkring halvdelen af dette niveau og er mindst i det færøske fiskeri. Omsætningen er størst i Norge med 2,0 mia. DKK, hvilket er ca. fire gange så stort som i det færøske fiskeri. Omsætningen i de britiske og islandske fartøjsgrupper udgør omkring to tredjedele af omsætningen i det norske fiskeri. Omsætningen i det danske fiskeri er omkring halvdelen af den britiske.

Antallet af fartøjer er med 45 højest i Norge, men dette ligger på niveau med de andre lande med undtagelse af Færøerne, hvor der kun er 8 fartøjer. Fartøjsstørrelsen i gennemsnit er til gengæld den største på Færøerne målt som brutto-tons, efterfulgt af Storbritannien. De andre land har fartøjs størrelser på omkring halvdelen af den færøske. Vedrørende motorkraft er de færøske fartøjer langt de kraftigste, mens de britiske fartøjer som nummer to kun har halvdelen af motorkraften i gennemsnit pr. fartøj. Også forsikrings- 
værdien er størst på Færøerne, mens Norge har den næsthøjeste. Forsikringsværdi er angivet ved værdi af fartøjerne i gennemsnit uden kvoter.

Kapacitetsudnyttelsen er højest i Island, da de islandske fartøjer er på havet i gennemsnit 320 dage om året. Derefter kommer de færøske fartøjer. Danmark og Norge har lidt lavere antal havdage. Storbritannien har kun 113 havdage i gennemsnit pr. fartøj. Dette lavere tal skal ses i sammenhæng med, at fiskeriet primært er efter makrel, som er sæsonbetonet.

De udvalgte fartøjsgrupper udgør i gennemsnit omkring $20 \%$ af den samlede fiskeri for landene, målt på landingsværdi. Danmark ligger højest med $26 \%$ og Island lavest med $18 \%$.

Til sidst er der angivet, hvor stor en del af fangsten der går til industri, dvs. hvor stor en andel der bliver forarbejdet til fiskemel og olie. Dette afhænger af, hvilke arter der fiskes. For Island og Færøerne er det over halvdelen, hvilket hænger sammen med at både Færøerne og Island fisker store mængder blåhvilling, som i stort omfang anvendes til produktion af fiskemel og olie. Endvidere fisker islandske fartøjer lodde, der også avendes til fiskemel og olie (jf. tabel 3.1). For de øvrige lande dominerer sild og makrel, som i de fleste tilfælde anvendes til konsum.

De seks udvalgte fartøjsgruppers vigtigste fiskearter er angivet i tabel 3.2. Tabellen inkluderer alene arter, der samlet bidrager med mindst $80 \%$ af den samlede landingsværdi for fartøjsgruppen.

Tabel 3.2. Landinger fra de udvalgte fartøjsgrupper af de arter, der indgår i analysen, $2007^{1}$.

\begin{tabular}{|c|c|c|c|c|c|c|}
\hline & Island & Norge & Færøerne & Danmark & Storbritannien & Total \\
\hline \multicolumn{7}{|l|}{ Landingsværdi (mio. DKK): } \\
\hline Nordsøsild & . & . & . & 203 & 181 & 384 \\
\hline Norsk vårgydende sild & 304 & 640 & 133 & 58 & . & 1135 \\
\hline Makrel & . & 413 & 97 & 180 & 958 & 1648 \\
\hline Blåhvilling & 257 & 634 & 284 & 65 & . & 1248 \\
\hline Tobis & & . & . & 111 & . & 111 \\
\hline Lodde & 451 & . & . & . & . & 451 \\
\hline Andet & 223 & 313 & 48 & 91 & 308 & 983 \\
\hline Total & 1.236 & 2.000 & 562 & 708 & 1.447 & 5953 \\
\hline \multicolumn{7}{|c|}{ Landingsmængde (1.000 tons): } \\
\hline Nordsøsild & & & & 79 & 57 & 136 \\
\hline Norsk vårgydende sild & 176 & 276 & 59 & 23 & . & 534 \\
\hline Makrel & . & 57 & 13 & 24 & 128 & 222 \\
\hline Blåhvilling & 235 & 427 & 243 & 50 & . & 955 \\
\hline Tobis & . & . & . & 93 & . & 93 \\
\hline Lodde & 307 & . & . & . & . & 307 \\
\hline \multicolumn{7}{|l|}{ Gennemsnit pris (kr./kg.): } \\
\hline Nordsøsild & & & & 2,57 & 3,18 & 2,82 \\
\hline Norsk vårgydende sild & 1,73 & 2,32 & 2,25 & 2,52 & & 2,13 \\
\hline Makrel & & 7,25 & 7,46 & 7,50 & 7,48 & 7,42 \\
\hline Blåhvilling & 1,09 & 1,48 & 1,17 & 1,30 & & 1,30 \\
\hline Tobis & & & & 1,19 & & 1,19 \\
\hline Lodde & 1,47 & & & & & 1,47 \\
\hline
\end{tabular}

Noter: ${ }^{1)}$ Arter, der indgår i analysen, er valgt blandt de vigtigste for fartøjsgruppen, således de omfatter mindst $80 \%$ af fangstværdien. Fartøjerne kan således fange andre arter, selvom de ikke er nævnt. Landingsværdier og mængder indeholder både fisk til konsum og industri. Landingsdata fra Rusland er ikke tilgængelige.

Kilder: Statistics Iceland (a), Norges Sildesalgslag, Færøernes Statistiske kontor, Fiskeridirektoratet i Danmark og STECF). 
Det ses, at der er størst landingsværdi i makrelfiskeriet, mens sild (de to bestande lagt sammen) har den næststørste værdi samlet. Derefter kommer blåhvilling og de andre arter. Det fremgår af tabellen, at næsten alle landene fisker sild, makrel og blåhvilling, mens tobis og lodde er forbeholdt Danmark og Island. Det bør bemærkes, at tabellen hverken viser, at Norge i 2007 fiskede lodde, eller Island makrel, men det var i så forholdsvis små mængder, at det ikke er med i opgørelsen pga. den anvendte 80 \% -regel (jf. tabel 3.2, note 1).

Hvis vi sammenligner med mængderne ses, at blåhvilling udgør langt den største mængde, sild er næststørst og derefter lodde, mens makrel er på fjerde pladsen. Dette betyder, at makrel har langt den største værdi pr. kg., mens sild udgør den næststørste landingspris. Blåhvilling, lodde og tobis har en lavere værdi pr. kg. Dette skyldes, at disse tre sidste for det meste bliver landet som industrifisk og derfor til lidt over $1 \mathrm{kr} . / \mathrm{kg}$. I gennemsnit. De to vigtigste arter bliver for det meste landet til konsum og til en højere pris. Og her har makrel langt højere pris end sild pr. kg. (ca. 2,5 kr./kg. i forhold til $7,5 \mathrm{kr} . / \mathrm{kg}$.). I tabellen ses, at der ikke er så store prisforskelle mellem landene, men hvis Rusland var med, var det sandsynligt større forskelle, da Rusland især lander blåhvilling til konsum.

Nedenfor vises en tabel over, hvor stor del af det samlede fiskeri, de betragtede case studier mængdemæssigt dækker af de enkelte fiskebestande.

Tabel 3.3. Dækning af case studie i tusind tons 2007

\begin{tabular}{lrrr}
\hline & Case studie & Fiskeri i alt & Case studiet i procent \\
\hline Nordsøsild & 136 & 341 & $40 \%$ \\
Norsk vårgydende sild & 534 & 1.243 & $43 \%$ \\
Makrel & 222 & 461 & $48 \%$ \\
Blåhvilling & 955 & 1.583 & $60 \%$ \\
Tobis & 93 & 204 & $46 \%$ \\
Lodde & 307 & 377 & $81 \%$ \\
\hline
\end{tabular}

Kilde: NEAFC (2009).

Af tabel 3.3. fremgår, at case studiet omfatter omkring halvdelen af de fleste arter, bortset fra lodde, hvor case studiet inkluderer $81 \%$. Årsagen er, at Island har hele sit loddefiskeri med. Hvis vi sætter priserne ind fra tabel 3.2, er værdien af det samlede fiskeri af disse arter omkring 9,8 mia. DKK, og omkring 5 mia. DKK (50 \%) er dækket af denne undersøgelse. Herudover kommer andet pelagisk fiskeri på omkring 1 mia. DKK (jf. tabel 3.2).

\subsection{Biologisk rådgivning}

I tabel 3.4 vises en oversigt over udnyttelsesgraden af de vigtigste bestande, som de udvalgte fartøjsgrupper fisker på (2007 bestandsvurderinger). Det ses, at halvdelen af Norges fiskeri foregår på arter, der er underudnyttede, mens Færøerne tilsvarende har næsten tre fjerdedele af sit fiskeri på arter, der er underudnyttede. Dette hænger sammen med, at sildebestanden og 
blåhvillingbestanden var i god stand i 2007, som det kan ses af tabel 3.5. Storbritannien og Danmark har mindre dele af sit fiskeri på underudnyttede arter, og Danmark har omkring en fjerdedel af sit fiskeri på arter, der er overudnyttede. Her er tale om tobis og andre fiskearter. Storbritannien har intet fiskeri i denne kategori.

Tabel 3.4. Udnyttelsesgrad af vigtigste bestande (\%) ${ }^{1}$.

\begin{tabular}{|c|c|c|c|c|c|}
\hline & Island & Norge & Færøerne & Danmark & $\begin{array}{l}\text { Storbri- } \\
\text { tannien }\end{array}$ \\
\hline Underudnyttet & 45 & 52 & 74 & 8 & 25 \\
\hline Fuldt udnyttet & 37 & 29 & 17 & 54 & 67 \\
\hline Overudnyttet & 0 & 8 & 0 & 26 & 0 \\
\hline Nedfisket eller under genopretning & 0 & 0 & 0 & 0 & 0 \\
\hline Ukendt & 18 & 11 & 9 & 12 & 8 \\
\hline Total & 100 & 100 & 100 & 100 & 100 \\
\hline
\end{tabular}

Noter: Underudnyttet betyder her, at gydebiomassen efter arten er under det maksimale i biologisk forstand. Når bestanden er fuldt udnyttet, er den nuværende biomasse lig med den maksimale biomasse. Når så bestanden er overudnyttet er gydebiomassen under det maksimale.

Kilde: Beregninger baseret på ICES (2008).

I figur 3.1 ses den biologiske udvikling for de tre største bestande fra 2000 til 2008, angivet ved et indeks. Her ses, at gydebiomassen for nordsøsild og blåhvilling er gået op indtil midten af perioden. Siden er gydebiomassen gået ned til næsten samme niveau igen som i 2000. Makrel og især norsk vårgydende sild er gået op siden 2000. Rekrutteringen af norsk vårgydende sild har haft store variationer i perioden og er i 2008 omkring dobbelt så stor som i 2000. Det samme er i mindre grad, også gældende for makrel. Vedrørende nordsøsild er rekrutteringen ikke god. Og især for blåhvilling er rekrutteringen meget lav i forhold til 2000.

Figur 3.1. Udvikling i gydebiomasse og rekruttering af udvalgte bestande, år $2000=100$.

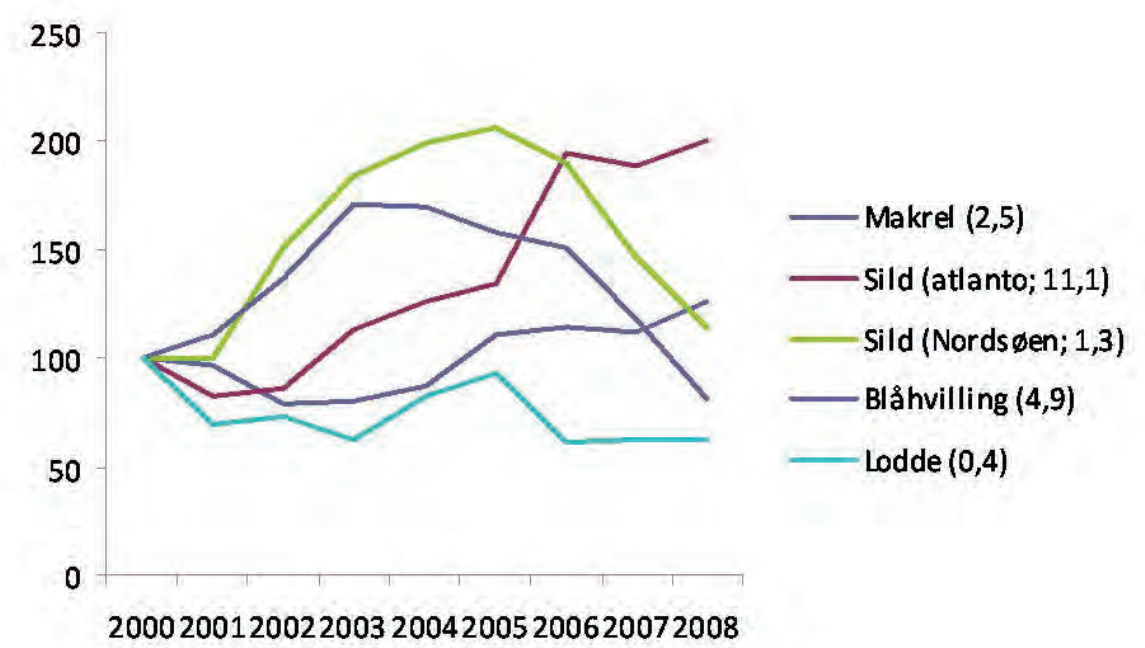

Gydebiomasse 


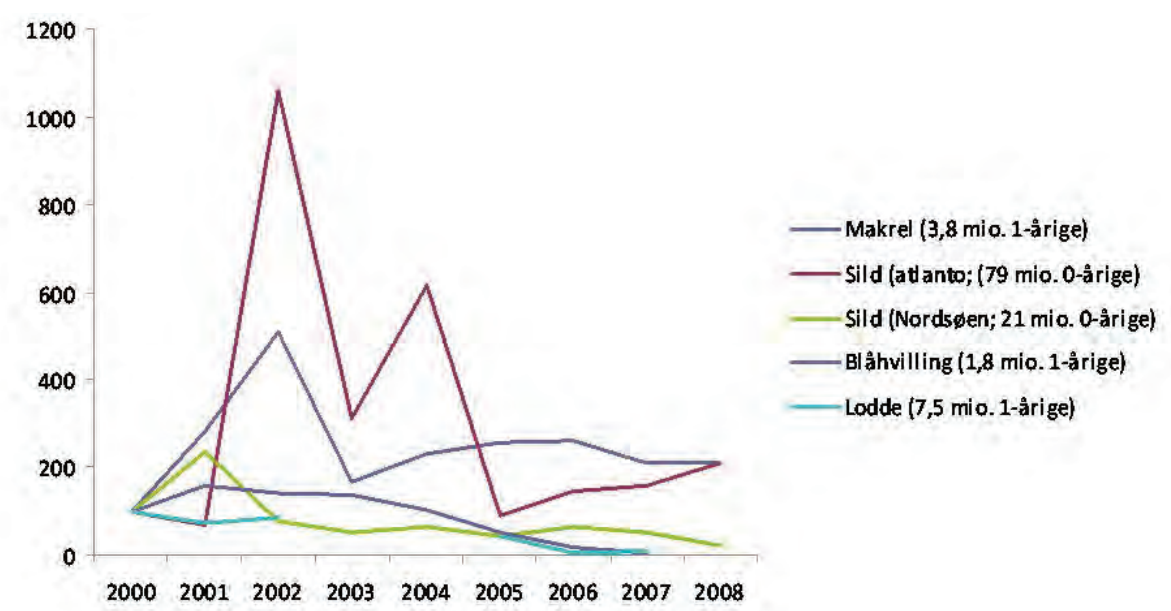

Rekruttering

Note: Gydebiomasse i år 2007 i mio. tons og rekruttering i stk. i år 2007 er angivet i parentes. Kilde:ICES (2008) og Islands Havbiologiske Forskningscenter

Tabel 3.5 viser tallene for gydebiomasse og den biologiske rådgivning omkring fiskedødelighedsniveau for de pelagiske arter i Nordøstatlanten ifølge det Internationale Havforskningsråd (ICES).

Her ses, at for norsk vårgydende sild og blåhvilling er der mere end dobbelt så høj gydebiomasse end den gydebiomasse der giver de største vedvarende fangster (Maximum Sustainable Yield = MSY), så her kan man sige, at fiskeriet er underudnyttet. For nordsøsild, lodde og makrel er gydebiomassen omkring det som giver MSY-udnyttelse og er derfor fuldt udnyttet. For tobis er gydebiomassen kun omkring halvdelen af MSY-biomassen, og bestanden er derfor overudnyttet.

Tabel 3.5. Biologisk rådgivning: gydebiomasse 2007, gydebiomasser der giver de største vedvarende fangster, og rådgivning om fiskeridødelighedsniveau 2008, tons.

\begin{tabular}{|c|c|c|c|}
\hline & \multicolumn{2}{|c|}{ Gydebiomasse } & \multirow[t]{2}{*}{ Fiskeridødelighedsniveau } \\
\hline & Faktisk 2007 & Maksimal $^{1}$ & \\
\hline Nordsøsild & 952.774 & 1.300 .000 & Bæredygtigt \\
\hline Norsk vårgydende sild & 11.836 .000 & 5.000 .000 & Bæredygtigt \\
\hline Makrel & 2.505 .033 & 2.300 .000 & Risiko for ikke at være bæredygtigt \\
\hline Blåhvilling & 5.995 .302 & 2.250 .000 & Bæredygtigt \\
\hline Tobis & 352.169 & 600.000 & Referencepunkter ikke defineret \\
\hline Lodde (Island) & 400.000 & 410.000 & Bæredygtigt \\
\hline
\end{tabular}

Note 1: Spalten med maksimal er maksimal i biologisk forstand, dvs. den gydebiomasse, der giver de største vedvarende fangster. Den faktiske gydebiomasse kan således godt være større end maksimal som vi ser for f.eks. norsk vårgydende sild, men så er bestanden i biologisk forstand underudnyttet.

Kilde: ICES (2008)

I tabel 3.5 ses endvidere, at de fleste fiskerier var bæredygtige i 2007, men makrel havde en risiko for, at fiskeriet ikke var bæredygtigt, og for tobis var referencepunkterne ikke definerede. Siden 2007 er der sket det, at der i 2010 faktisk kun er norsk vårgydende sild, der bliver bæredygtigt udnyttet, jf. ICES. 


\subsection{International forvaltning}

Forvaltningen af de pelagiske arter er for en stor del varetaget af landene i fællesskab. For norsk vårgydende sild, makrel og blåhvilling er det NEAFC (North East Atlantic Fisheries Commision), der regulerer fiskeriet. NEAFC har alle landene omkring Nordøstatlanten som medlemmer. NEAFC's reguleringer baserer sig på beslutninger, som landene bliver enige om; hvor stor den årlige totalkvote skal være og hvordan den skal fordeles mellem lande. Denne fordeling er i praksis foregået som forhandlinger mellem de enkelte lande, hvor der til sidst er opnået enighed om en fordeling, der gælder indtil næste forhandlingsrunde. En opgave for NEAFC er at regulere fiskeriet i det internationale farvand mellem Island, Norge og Færøerne (Smutthavet i figur 3.2). Dette område får en del af det samlede fiskeri og her får både kyststater og andre stater lov til at fiske (f.eks. Rusland). Fiskeriet i dette område svarede i 2007 til $12 \%$ af den samlede fangstmængde for de tre arter. EU's totalkvoter fordeles til medlemsstaterne via en fast fordelingsnøgle ud fra princippet om relativ stabilitet.

For lodde og nordsøsild er der bi(tri)-laterale aftaler mellem de involverede parter: Island, Norge og Grønland for lodde og Norge og EU for nordsøsild. For tobisfiskeriet fordeles kvoten ud fra relativ stabilitet. EU har dog givet kvote til Norge på forsøgsplan i den analyserede periode.

Figur 3.2 viser et kort over området som case studiet dækker, idet det bemærkes at EU-zonen inkluderer alle medlemsstaters zoner. 
Fgur 3.2 De økonomiske zoner i Nordøstatlanten.

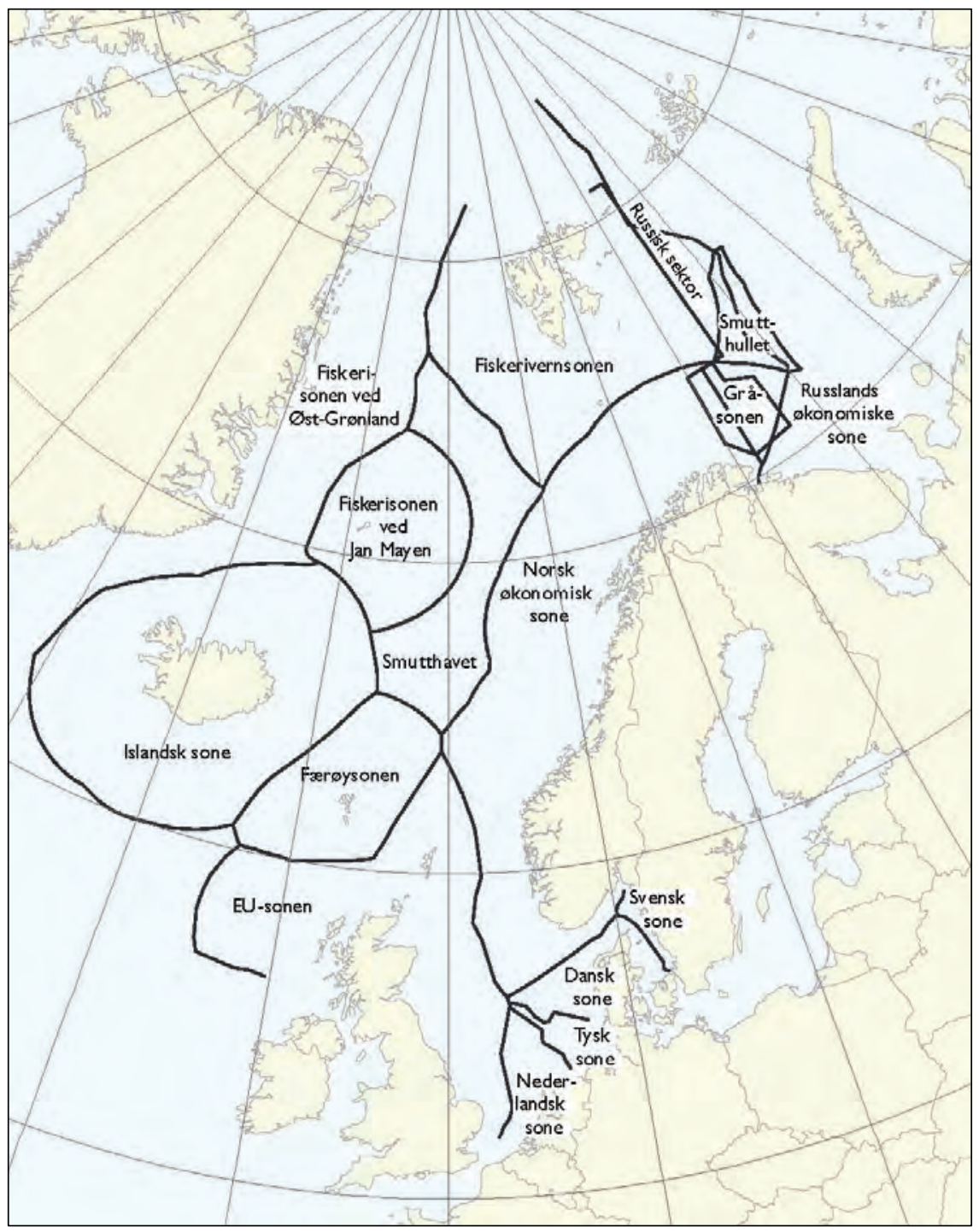

Kilde: Gjøsæter, Harald, Are Dommasnes,Tone Falkenhaug, Marie Hauge, Edda Johannesen, Erik Olsen \& Øystein Skagseth. 2009. Havets Ressurser og Miljø 2009. Fisken og havet, særnr. 1-2009.

\section{Norsk vårgydende sild}

Fiskeriet efter denne art har en meget lang historie særlig i Norge, Island og på Færøerne. Der var rigtigt meget sildefiskeri i 1950’erne og 1960’erne. Efter dette kollapsede fiskeriet med bund i 1972 og kom først rigtigt i gang igen omkring år 1993-1994. I de mellemliggende år var norsk vårgydende sild næsten kun i norsk farvand. Efter 1994 begyndte den igen at følge det oprindelige mønster. Dette ledte til forhandlinger om fordeling af fiskeriet på arten. I 1996 blev Norge, Rusland, Færøerne og Island enige om at dele silden (EU kom med i 1997). Norge fik den største del. Delingen af silden byggede på de gamle fiskerimønstre, hvilket Norge fandt mindre tilfredsstillende. Omkring 2003-2004 var der igen uenighed omkring fordeling af sil- 
defiskeriet. Det resulterede i, at der i 2003 til 2006 ikke var nogen aftale, men den blev alligevel ikke overfisket. I 2007 blev der igen opnået enighed ved at Norge fik en større del.

\section{Makrel}

Der blev lavet en aftale om makrel i 2000, som delte den mellem EU, Norge og Færøerne. Denne aftale har været gældende indtil 2009, men er endnu ikke forlænget i 2010. De senere år har der været stor uenighed om makrel. I 2008 indførte EU en sydkomponent af makrelbestanden og satte sin egen kvote herfor. I 2009 svarede Norge og Færøerne igen med at sætte en tilsvarende nordkomponent. Ydermere er migrationsmønstrene ændret for makrel de senere år, således at makrel som noget nyt nu også findes i islandsk farvand. Dette betyder, at islandske fartøjer har fisket omkring $20 \%$ af den samlede kvote i 2008 og fremefter (i 2007 var det omkring 7 \%). Dette på trods af at Island ikke er del af aftalen om makrel (jf. tabel 3.6). At migrationsmønstrene er ændrede, har fået Færøerne til at kræve en større del af den samlede kvote, da makrel nu er mere i færøsk farvand end før. Disse forhold har ført til, at det ikke har været muligt at nå til enighed om makrelfiskeriet for 2010 (endnu i juli 2010).

\section{Blåhvilling}

Fiskeriet efter blåhvilling startede i 1970'erne. Især Rusland og Norge fiskede denne art dengang. Rusland fiskede ikke i eget farvand, men især omkring Færøerne og i Norge. Færøerne, EU og Island har siden også fisket store mængder blåhvilling. Forhandlingerne om at dele blåhvilling startede omkring 2000, og der blev opnået enighed i slutningen af 2005. Delingen blev, at EU, Island, Norge og Færøerne fik omkring en fjerdedel hver.

Ud over disse aftaler indgås bilaterale aftaler. F. eks har Færøerne indgået aftale med Norge om, at færøske fartøjer kan fiske makrel i norsk farvand, da den har en langt højere værdi, end hvis den fiskes i færøske farvand. EU og Norge har lignende aftaler. Men der er begrænsninger i disse adgange med hensyn til at fiske i andre landes farvande. F.eks. kan færøske fartøjer kun fiske lidt mere end halvdelen af sin makrelkvote i norsk farvand.

\section{Lodde}

Lodde fiskes hovedsagelig nord for Island og i havet omkring Jan Mayen (tilhørende Norge). Således blev lodde oprindeligt i 1980 delt mellem Norge og Island. Senere i 1989 blev Grønland også en del af denne aftale. Aftalen blev fornyet igen i 1998 til den nuværende aftale. Denne aftale er ikke som de ovenstående en del af NEAFC, da lodde ikke fiskes i internationalt farvand. Ud over dette er der også en bestand af lodde i Barentshavet, og denne er delt mellem Norge og Rusland, men der har ikke været fisket på den siden 2003. 


\section{Nordsøsild}

Denne bestand af sild reguleres ligesom lodde ikke via NEAFC, men bliver fordelt mellem EU og Norge i bilaterale aftaler. Inden for EU bliver den fordelt som andre kvoter ud fra relativ stabilitet. Ligesom norsk vårgydende sild har nordsøsild også en lang historie med næsten udryddelse i 1960'erne og 1970'erne. I 1986 blev Norge og EU enige om at dele nordsøsild, hvor Norges andel bliver større, jo større gydebiomassen er: Norges andel ligger på $25 \%, 29 \%$ eller $32 \%$.

\section{Tobis}

Denne art bliver kun fisket i Nordsøen og er ikke del af nogen international aftale. Inden for EU bliver arten fordelt ud fra relativ stabilitet, men det er hovedsagelig danske fartøjer, der fisker tobis. Dog har der også været norske fartøjer, der har fisket tobis på forsøgsbasis.

Tabel 3.6 viser fordelingen af de nævnte arter mellem kyststaterne (tobis undtaget). Fordelingen viser ikke, hvor meget der er allokeret til internationalt farvand. Rusland har f.eks. ret til at fiske en del makrel i internationalt farvand.

Tabel 3.6: Fordelingen i aftaler af arterne i case studiet blandt kyststaterne 2007

\begin{tabular}{lrrrrrr}
\hline & Island & Norge & Færøerne & Rusland & EU & Total \\
\hline Nordsøsild & - & $29 \%$ & - & - & $71 \%$ & $100 \%$ \\
Norsk vårgydende sild & $15 \%$ & $61 \%$ & $5 \%$ & $13 \%$ & $6 \%$ & $100 \%$ \\
Makrel & - & $35 \%$ & $5 \%$ & - & $60 \%$ & $100 \%$ \\
Blåhvilling & $18 \%$ & $26 \%$ & $26 \%$ & - & $31 \%$ & $100 \%$ \\
Lodde & $81 \%$ & $8 \%$ & - & - & - & $89 \%$
\end{tabular}

Note: '-' betyder, at landet ikke er med i denne aftale. Delingen inden for EU er, at den danske og den britiske del for blåhvilling er $16 \%$ hver af den samlede EU kvote. Vedr. makrel får Danmark $5 \%$, mens Storbritannien får halvdelen af EU's kvote.

Kilde: Aftaler om forvaltning af fiskeriet efter norsk vårgydende sild, makrel, blåhvilling og nordsøsild

\subsection{National forvaltning}

Forvaltningen af fiskerierne i de enkelte lande er ikke så forskellig. Dette kan være en konsekvens af, at der i de fleste tilfælde er tale om delte arter. Når de enkelte lande får en specificeret del af den samlede kvote, betyder det at de f. eks ikke kan have indsatsforvaltning, da det så vil være svært at håndhæve en samlet kvote. En anden form for forvaltning er at sætte en samlet kvote og lade fiskeriet være frit, indtil kvoten er opfisket. For blåhvilling, hvor der først kom en kvote fra 2006 og frem, var der ikke megen regulering i landene tidligere, bortset fra en deltagerbegrænsning ved brug af licenser. Ud over de nævnte reguleringer er der også tekniske reguleringer i form af begrænsninger af bifangst og lukkede områder med gydebestande. I det følgende gennemgås hovedtrækkene i de nationale reguleringer, hvor en mere detaljeret gennemgang findes i bilag 2 . 


\section{Island}

Fiskeriet i Island er koncentreret om norsk vårgydende sild, blåhvilling og lodde. De senere år er der også fisket en stor mængde makrel. Fiskeriet efter disse arter foregår for det meste i eget farvand, mens fiskeriet efter blåhvilling også foregår i færøsk og EU farvand.

Vedrørende adgangsbegrænsning har Færøerne og Island bilaterale aftaler om, at begge lande kan fiske deres landekvote frit i hinandens farvand. Ellers har Island kun få aftaler med andre lande omkring adgang.

En stor del af fiskeriet i Island går til industri, jf. tabel 3.1, og fiskemel og olieproduktionen er vigtig i Island. Forvaltningen i Island har i hele perioden været individuelt omsættelige kvoter for alle fiskerier. For blåhvilling var der dog ikke nogen forvaltning frem til år 2006, hvor der kom en international aftale om fordeling. Før 2006 var fiskeriet kun reguleret ved begrænsninger i licenserne.

Norge

Fiskeriet i Norge omfatter ifølge tabel 3.2 især de tre internationalt regulerede arter, makrel, norsk vårgydende sild og blåhvilling. Fiskeriet foregår for det meste i norsk farvand, men fiskeriet efter blåhvilling foregår overvejende uden for Norge i både færøsk og EU farvand. I Norge er fiskeriet efter disse arter reguleret med individuelle ikke-omsættelige kvoter. Men fartøjerne sælges normalt med kvote, så på denne måde er kvoterne omsættelige, da kvoterne bliver kapitaliseret i værdien af fiskefartøjet. Denne forvaltning var gældende for makrel og sild i hele perioden. Blåhvillingfiskeriet var ureguleret indtil 2006. Udover dette er der tekniske reguleringer, sådan at der er begrænsninger på størrelsen fisken som bliver fanget og der er begrænsninger på bifangsten. Ligesom der er gydeområder, er der lukkede for fangst af sild.

\section{Færøerne}

Fiskeriet på Færøerne er ligesom i Norge koncentreret om makrel, norsk vårgydende sild og blåhvilling. Fiskeriet efter makrel foregår for det meste i norsk farvand, da der fås den bedste pris, mens sildefiskeriet foregår både i færøsk og norsk farvand. Blåhvillingfiskeriet foregår i EU og færøsk farvand.

Færøske fartøjer lander makrel og sild primært til norske fiskeopkøbere til konsum. Blåhvilling bliver for det meste landet til Færøernes eneste fiskemelsfabrik.

Færøerne har siden 1977 lavet bilaterale aftaler med Rusland (tidligere med Sovjetunionen) om, at Rusland fisker blåhvilling og makrel i færøsk farvand, og at Færøerne til gengæld fisker torsk i Barentshavet. Fiskeriet af især blåhvilling af færøske fartøjer har været meget lille frem til omkring år 2000, hvor fiskeriet voksede sig stort. Vedrørende adgang til at fiske i norsk farvand indebærer aftalen, at kun en del af kvoten af makrel kan fiskes i 
norsk farvand. Den øvrige del bliver byttet med Rusland, så Rusland fisker makrel i færøsk farvand.

Forvaltningen for makrel og sild har været baseret på individuelt omsættelige kvoter i hele perioden. For blåhvilling var der ligesom i de andre lande ikke nogen forvaltning frem til år 2006. Før det var blåhvillingfiskeriet kun reguleret via begrænsning i antal licenser. Efter 2006 er blåhvilling reguleret med en samlet kvote, hvor fiskeriet er frit, indtil kvoten blev nået. Dette blev ændret i 2009 til at også blive individuelt omsættelige kvoter. Udover dette er der reguleret med tekniske reguleringer som f.eks. lukkede område og maskeviddebegrænsninger.

\section{Rusland}

Rusland fisker både sild, makrel og blåhvilling. Ruslands fiskeri af blåhvilling er til forskel fra de andre lande næsten udelukkende til konsum. Fangsten sælges til russiske forbrugere og til det øvrige Østeuropa. Som tidligere nævnt, er Rusland kun delvist med i den internationale aftale om norsk vårgydende sild. For de andre arter er Rusland afhængig af rettigheder til at fiske i internationalt farvand, såvel som af aftaler med Færøerne, Norge og EU. Udover disse arter har Rusland også en aftale med Norge som inkluderer fiskeri efter lodde i Barentshavet, men dette fiskeri har ligget stille siden 2003.

Fiskeriet er reguleret ved, at fiskeriselskaberne modtager deres del af den samlede kvote gældende i fem år baseret på historisk fiskeri de sidste tre år. Selskaberne har ofte flere fartøjer og kan dele kvoterne mellem disse. Der er også tekniske reguleringer i form af maskestørrelse, bifangst og størrelse på den fangede sild og lodde.

\section{Danmark}

Det danske pelagiske fiskeri er efter nordsøsild, norsk vårgydende sild og makrel til konsum. Danmark fisker desuden blåhvilling, tobis og andre arter til industri. Danmark fisker ikke i væsentligt omfang lodde.

Det danske pelagiske fiskeri foregår for det meste i Nordsøen. En del af fiskeriet foregår med fartøjer over $40 \mathrm{~m}$, som er dækket i dette case studie. Danmark er en del af EU's fælles fiskeripolitik. Forvaltningen af det danske sildefiskeri har siden 2003 været baseret på individuelt omsættelige kvoter. Makrel- og industrifiskeri var baseret på individuelt ikke-omsættelige kvoter fra 2004-2006. Siden 2007 har der været individuelt omsættelige kvoter også for disse arter. Der eksisterer endvidere en begrænsning, således at ingen enkelt ejer kan eje mere end $10 \%$ af de samlede kvoter.

Før 2003 var forvaltningen af det pelagiske fiskeri i Danmark baseret på årsmængder og rationer. For industrifiskeriet var der rationer med perioder på en måned eller mindre. For silde- og makrelfiskeriet var der årsmængder. Desuden har der været reguleret med licenser. Udover dette har der også 
været tekniske reguleringer med maskevidde- og bifangstreguleringer samt lukkede områder.

\section{Storbritannien}

Især makrel, men også sild, er vigtige arter for Storbritannien. Industrifiskeriet har kun mindre betydning med blåhvilling som den eneste art, der fiskes i et nævneværdigt omfang. Der fiskes sild især Nordsøen og i farvandet vest for Skotland, samt i Norskehavet. Makrel fiskes vest for Skotland, mens blåhvilling fiskes vest for de britiske øer.

Forvaltningen af det britiske fiskeri er også baseret på individuelle kvoter. Disse er dog rettet mod producentorganisationerne, der så har ret til at dele de tildelte kvoter ud til medlemmerne. Det betyder, at de enkelte fartøjer ikke har lovmæssig ret til deres fiskeri. Delingen af disse kvoter til de enkelte producentorganisationer blev fastsat i 1999 på grundlag af fangstmønstret for perioden fra 1994-96. Storbritannien anvender som andre EU lande også tekniske reguleringer og lukkede områder. 


\section{Størrelsen af det samfundsøkonomiske afkast}

Det samfundsøkonomiske afkast af et fiskeri kan defineres som „det nettooverskud, der er tilbage, efter at arbejdskraft og kapital har opnået en aflønning på niveau med, hvad der opnås i andre erhverv“. Begrebet samfundsøkonomisk afkast adskiller sig i visse henseender fra begrebet overskud. Overskud er en privatøkonomisk størrelse, der angiver differencen mellem et firmas totale indtægter og dets totale omkostninger. Det samfundsøkonomiske afkast inddrager derimod også den forskel, der måtte eksistere mellem aktuel aflønning og alternativ aflønning af arbejdskraft og kapital samt evt. offentligt provenu fra en ressourcebeskatning eller salg af rettigheder. Ved alternativaflønningen af arbejdskraft og kapital forstås den aflønning, der svarer til aflønningen i lignende erhverv tilpasset samme arbejdsvilkår og risiko. Endvidere inddrages generelle beskatningsspørgsmål ikke ved beregning af det samfundsøkonomiske afkast, idet dette spørgsmål alene påvirker fordelingen af afkastet.

Det samfundsøkonomiske afkast er tæt forbundet til begrebet ressourcerente. Ressourcerenten ved fiskeri kan beskrives som det vedvarende økonomiske afkast, samfundet får ud af at eje en fiskebestand. Ressourcerenten opstår, fordi fiskeressourcerne er begrænsede og fornybare hvorfor det er muligt med en passende fiskeriindsats vedvarende at høste et samfundsøkonomisk overskud. Ressourcerenten vil forsvinde, hvis der åbnes for frit fiskeri, idet flere vil starte i erhvervet, og det øgede fiskeritryk vil reducere bestanden, indtil fiskerne tjener det samme som i andre erhverv. Uden forvaltning vil ressourcerenten derfor være nul, men indføres forvaltning, der begrænser adgangen til fiskeri, vil det være muligt vedvarende at sikre en positiv ressourcerente. Ressourcerentens størrelse afhænger således af forvaltningen. Fiskeriet afkaster ydermere en producentrente, der også benævnes en infra-marginal rente, som opstår, fordi nogle fiskere er dygtigere og mere effektive end andre. Den infra-marginale rente vil findes både i reguleret og i frit fiskeri. I praksis er det ikke muligt at skille ressourcerente og den infra-marginale rente. Derfor vil det samfundsøkonomiske afkast, der beregnes her, være summen af disse to størrelser.

Et stort samfundsøkonomisk afkast kan have sin baggrund i et effektivt fiskeri, hvor forvaltningen sikrer en økonomisk effektiv forvaltning af fiskebestandene, men det kan også skyldes eksterne faktorer som høje priser eller en gunstig bestandsudvikling af naturlige årsager. Omvendt kan de mulige forklaringer på et lavt afkast søges i manglende økonomisk effektivitet såsom overkapacitet i de pågældende fartøjsgrupper, lav produktivitet eller sub-optimal forvaltning af fiskebestandene og et heraf følgende højt om- 
kostningsniveau, men det kan også have sin forklaring i eksterne faktorer som lave priser eller en af andre grunde svigtende fiskebestande. De eksterne forhold kan imidlertid ikke være forklaring på en vedvarende positiv ressourcerente, da gunstige eksterne vilkår vil forøge fiskeriindsatsen. Derimod kan de infra-marginale gevinster vedvarende være positivt påvirket af gunstige eksterne forhold.

Omkostningerne til aflønning af arbejdskraft og kapital i alternativ anvendelse fastsættes som det niveau, der realistisk vurderet kan opnås i tilsvarende erhverv. Der tages således ikke specielt hensyn til, at det kan være nødvendigt at tilbyde fiskere en højere løn end $\mathrm{i}$ andre erhverv med et tilsvarende uddannelses- og kvalifikationsniveau for at kunne opretholde rekrutteringen til fiskeriet. Der tages derfor heller ikke højde for, at fiskeriet er et erhverv med en overrepræsentation af arbejdsulykker, og som kan indebære flere ulemper end i de fleste andre erhverv. Der ses desuden bort fra evt. øgede muligheder for at erstatte indenlandsk arbejdskraft med billigere udenlandsk arbejdskraft.

Tilsvarende er aflønning af kapital i alternativ anvendelse fastsat på grundlag af, hvad der realistisk vurderes at kunne opnås, såfremt den kapital, der er investeret i fiskefartøjer, investeredes i værdipapirer. Det tages således ikke i betragtning, at det kunne være nødvendigt at opretholde en højere kapitalaflønning i fiskeriet, såfremt det er forbundet med en højere risiko at investere i fiskefartøjer. Er dette tilfældet vil det samfundsøkonomiske afkast blive overvurderet.

I de følgende afsnit gives en gennemgang af analyserne af det samfundsøkonomiske afkast for perioden 2000-2008, som består af analyser af det samfundsøkonomiske afkast for de seks case studier for året 2007 samt efterfølgende en analyse og karakteristik af de udviklingstendenser, der ses i det samfundsøkonomiske afkast for fire ud af de seks case studier for perioden 2000-08. Herefter følger en beregning og analyse af de maksimale samfundsøkonomiske afkast, samt en vurdering af hvordan det maksimale samfundsøkonomiske afkast kan opnås via forvaltning. Rusland er ikke inkluderet i beregningerne, da det ikke har været muligt at fremskaffe tilstrækkeligt detaljerede og præcise data.

\subsection{Det samfundsøkonomiske afkast for 2000-2008}

\section{Beregningsmetode}

Der anvendes to definitioner på det samfundsøkonomiske afkast:

A. „det nettooverskud, der på et givet tidspunkt er tilbage til aflønning af kapital og arbejdskraft ud over, hvad der opnås i andre erhverv“.

B. „det nettooverskud, der på et givet tidspunkt er tilbage til aflønning af kapital og arbejdskraft ud over, hvad der opnås i andre erhverv og efter fradrag af offentlige nettoudgifter til fiskeriet“. 
Det samfundsøkonomiske afkast kan således beregnes som:

Omsætning

-omkostninger (ekskl. arbejdskraft og kapital)

-omkostninger til arbejdskraft i alternativ anvendelse

-omkostninger til kapital i alternativ anvendelse

=Samfundsøkonomiske afkast A ekskl. off. nettoudg. til fiskeriet udover andre erhverv

-offentlige nettoudgifter til fiskeriet udover andre erhverv

=Samfundsøkonomiske afkast B inkl. off. nettoudg. til fiskeriet udover andre erhverv

Begge typer samfundsøkonomisk afkast beregnes i nærværende rapport som et regnskabsmæssigt resultat for et givet år, og de er baseret på beregninger gennemført i de fem case studier. Det samfundsøkonomiske afkast kan beregnes både uden fradrag af offentlige nettoudgifter til fiskeriet udover almindelige offentlige udgifter, som alle erhverv har gavn af(type A), såvel som efter fradrag af disse nettoudgifter (type B). Det samfundsøkonomiske afkast beregnes for fartøjsgrupper og inkluderer alene det afkast de betragtede fartøjsgrupper bidrager med. Det samfundsøkonomiske afkast kan være både positivt og negativt. Et positivt samfundsøkonomisk afkast betyder, at aflønningen af kapital og arbejdskraft i fiskeriet er større end i andre erhverv, mens et negativ samfundsøkonomisk afkast omvendt viser, at aflønningen er mindre end i andre erhverv. Ved beregningen af det samfundsøkonomiske afkast er der fratrukket faste omkostninger, således at man kan sammenligne med det potentielle afkast i en fremtidig situation, i hvilken alle omkostninger betragtes som variable. Herved kan det nuværende afkast vurderes i forhold til det maksimale.

Omsætningen inkluderer det enkelte fartøjsgruppes samlede indtægter, og omkostninger udgøres af alt andet end omkostninger til arbejdskraft og kapital, dvs. alle omkostningstyper som er nødvendige for at gennemføre fiskeriet, herunder til brændstof, redskaber og afskrivninger. Både omsætning og omkostninger kendes fra offentliggjorte regnskabsstatistikker.

Omkostninger til arbejdskraft i alternativ anvendelse angiver, hvad de ansatte i fartøjsgruppen kan opnå i løn, såfremt de var i beskæftigelse i andre erhverv, hvor der realistisk set kunne opnås beskæftigelse, uddannelsesniveau mv. taget i betragtning. Således benyttes et lønniveau for menige fiskere svarende til ufaglærte i industrien, og der regnes med løn på funktionærniveau for officererne. Fiskeriet er imidlertid et erhverv med en større grad af arbejdsulykker end en gennemsnitlig industriarbejdsplads, og desuden kan det indebære en række ulemper i form af vanskelige arbejdsforhold og længerevarende fangstrejser. Disse forhold kunne forklare eventuelle ekstra- 
omkostning med henblik på tiltrækning af den nødvendige arbejdskraft. I nærværende rapport beregnes denne løn for både officerer og menige fiskere, og det antages at $30 \%$ af lønudgifterne går til officerer og $70 \%$ til menige fiskere. Beregningen forudsætter, at fiskerne rent faktisk ville være i alternativ beskæftigelse. Hvis dette ikke er tilfældet, vil omkostninger til arbejdskraft i alternativ anvendelse være overvurderet, og det beregnede afkast således være undervurderet. Dette kan på kortere sigt være tilfældet, men antagelsen vil ikke gælde på lang sigt.

Omkostninger til kapital i alternativ anvendelse angiver, hvilken forrentning den kapital, der er investeret i fiskefartøjer, kan opnå, såfremt den blev investeret i andre kapitalgoder, fx aktier eller obligationer. I nærværende rapport beregnes den alternative forrentning på grundlag af fartøjernes forsikringsværdi, der antages at angive værdien af fartøjerne inkl. skrog, motor, redskaber mv., og som anses for det bedste skøn over værdien af kapitalapparatet. I værdien af kapitalapparatet indgår værdien af eventuelle fiskerirettigheder derfor ikke. Værdien af fiskerirettigheder har ikke betydning for størrelsen af det potentielle samfundsøkonomiske afkast og behandles i nærværende rapport alene i forbindelse med fordeling af afkastet mellem nuværende og tidligere ejere af fiskerirettigheder.

Størrelsen på den alternative forrentning fastsættes på grundlag af det danske Finansministeriums anbefalinger vedrørende den samfundsmæssige kalkulationsrente, der angiver det afkast, som ressourcerne ud fra en samfundsøkonomisk synsvinkel kunne have givet ved en alternativ anvendelse af den investerede kapital. Den alternative forrentning er på denne baggrund sat til $6 \%$ i nærværende rapport. Den norske oliefond har til sammenligning i perioden 2000-09 opnået en forrentning på 5,4 \% p.a. på de obligationsrelaterede investeringer. Disse størrelser ligger i den lave ende set i forhold til det reelle afkast af virksomheders kapital eller af afkastet på aktier og obligationer set over en længere periode. Der regnes med en alternativ forrentning, der er ens for alle landene, da kapitalmarkederne formodes at være integrerede. På den anden side er den forventede forrentning høj i forhold til den samfundsmæssige kalkulationsrente, der af mange bruges i samfundsøkonomiske projektvurderinger. Ud fra en række fagøkonomiske argumenter vil anbefalingen være $2-4 \%$.

Offentlige nettoudgifter til fiskeriet udover de almindelige offentlige udgifter til alle erhverv angiver de offentlige merudgifter til fiskerisektoren fratrukket brugerbetaling fra fiskeriet. Offentlige udgifter til fiskerisektoren udgøres i nærværende rapport alene af offentlige udgifter til fiskefartøjer, herunder offentlige tilskud til ophør, ophugning, fornyelse, modernisering og omkostningsreducerende transfereringer samt fiskeriforvaltningsomkostninger, herunder fx omkostninger til kontrol, biologiske undersøgelser og rådgivning. De offentlige udgifter kendes udelukkende for hele fiskerisektoren i de respektive fem lande og er derfor fordelt på de udvalgte fiskerier i forhold til disse fiskeriers andel af den samlede fangstværdi. Brugerbetaling eksisterer kun i Island og omfatter visse typer kontrolomkostninger. Offent- 
lige udgifter til andre erhverv kendes imidlertid ikke, og det er derfor antaget, at de offentlige udgifter til fiskeriet ud over de nævnte er på samme niveau som i andre erhverv.

Beregningen af det samfundsøkonomiske afkast baseres på en række beregningsforudsætninger for de enkelte poster, som indebærer, at resultaterne er behæftet med usikkerhed og derfor bør fortolkes med en vis forsigtighed.

\section{Data}

Data fra de fem case studier er fra 2007, som er det seneste år, hvorfra der kan fremskaffes de nødvendige data for alle landene. Disse tal danner basis for beregningerne af det nuværende samfundsmæssige afkast. Desuden er der for fire af landene (Danmark, Færøerne, Island og Norge) anvendt data for årene 2000-08 i beregningen af udviklingen i det samfundsmæssige afkast. De nødvendige data inkluderer regnskabsstatistik for fiskeriet, statistik over alternativ aflønning af arbejdskraft og kapital samt statistik over offentlige udgifter til fiskeriet. Regnskabsdata for fartøjsgrupperne findes i regnskabsstatistikkerne for fiskeriet i de pågældende lande. Aflønning af arbejdskraft og kapital i andre erhverv end fiskeriet kendes fra de nationale statistikkontorers løn- og kapitalmarkedsstatistik. Offentlige udgifter til fiskeriet kendes fra OECD (2004), og de færøske tal stammer overvejende fra et revisionsfirma (NOTA). En opsummering af de økonomiske data er givet i tabel 4.1.

Tabel 4.1. Økonomiske data.

\begin{tabular}{|c|c|c|c|c|c|}
\hline & Island & Norge & Færøerne & $\begin{array}{l}\text { Dan- } \\
\text { mark }\end{array}$ & $\begin{array}{r}\text { Stor- } \\
\text { britannien }\end{array}$ \\
\hline \multicolumn{6}{|l|}{ Regnskabsdata (mio. DKK) } \\
\hline Omsætning & 1.236 & 2.000 & 562 & 708 & 1.447 \\
\hline Variable omkostninger & 370 & 732 & 192 & 252 & 535 \\
\hline Afskrivninger & 61 & 212 & 51 & 167 & 199 \\
\hline Lønomkostninger & 335 & 551 & 173 & 167 & 343 \\
\hline Kapitalomkostninger $^{1}$ & 0 & 25 & 10 & 49 & 99 \\
\hline \multicolumn{6}{|l|}{ Alternativ aflønning ${ }^{2}$} \\
\hline Årsløn officerer andre erhverv (1.000 DKK) & 484.800 & 415.200 & 364.800 & 429.100 & 359.200 \\
\hline Årsløn besætning andre erhverv (1.000 DKK) & 322.500 & 298.300 & 255.400 & 300.400 & 251.500 \\
\hline Kapitalforrentning i andre erhverv (\%) & 6 & 6 & 6 & 6 & 6 \\
\hline \multicolumn{6}{|l|}{ Offentlige udgifter til fiskeriet (mio. DKK) } \\
\hline Tilskud & 0 & 2 & 6 & 12 & 2 \\
\hline Fiskeriforvaltning & 24 & 115 & 26 & 48 & 83 \\
\hline Brugerbetaling for kontrol & -1 & 0 & 0 & 0 & 0 \\
\hline
\end{tabular}

Noter:

1) Kapitalomkostninger, jf. regnskaber, er dog korrigeret for, at de er inkl. køb af fiskerirettigheder. For Danmark, Norge, Storbritannien og Færøerne er antaget, at $50 \%$ af kapitalomkostningerne er til indkøb af kvoter. For Island er der en nettokapitalindtægt på 48 mio. DKK, som antages ikke at være fiskerirelateret og derfor sættes til nul.

2) Den færøske og britiske alternative aflønning af arbejdskraft er beregnet med udgangspunkt i den danske korrigeret med forskellen i BNP.

Kilder: Fiskeriregnskabsstatistik (Statistics Iceland (b) og Eskja 2010, Fiskeridirektoratet Norge (a), Nota 2010, Fødevareøkonomisk Institut og STECF), Lønstatistik (Statistics Iceland (c), Norges Statistik, Danmarks Statistik og United Kingdom Statistics) samt tilskud og fiskeriforvaltningsomkostninger (OECD 2010 og Færøernes Hjemmestyre (b). 
Det samfundsøkonomiske afkast for 2007

Størrelsen af det samfundsøkonomiske afkast før fradrag af offentlige nettoudgifter (type A) for 2007 i de 6 case studier er vist i tabel 4.2. Det samlede samfundsøkonomiske afkast hænger i høj grad sammen med størrelse af omsætningen i de enkelte fiskerier. Afkastet er tydeligvis størst i Norge og Island med hhv. 559 og 530 mio. DKK, tæt efterfulgt af Storbritannien på 456 mio. DKK, og det er mindst i Danmark, hvor der er tale om 121 mio. DKK. Den færøske fartøjsgruppe genererer et samfundsøkonomisk afkast på 213 mio. DKK. Vurderes det samfundsøkonomiske afkast i forhold til omsætningen har det været højest i Island, Færøerne, Storbritannien og Norge i nævnte rækkefølge (hhv. 43 \%, 38 \%, 32 \% og 28 \%) og væsentligt lavere i Danmark med $17 \%$.

For de omhandlede case studier er både aflønningen af kapital og arbejdskraft større i den aktuelle situation end ved en alternativbetragtning. For fire af de betragtede lande fordeler det samfundsøkonomiske afkast sig med en mindre vægt til fordel for arbejdskraften, mens kapitalens andel er størst for Island. Det kan i øvrigt bemærkes, at aflønningen af fiskerne er høj sammenlignet andre erhverv; mere end dobbelt så høj ud fra en samlet vurdering.

Ser man på de omkostningstyper, der har størst indflydelse på størrelsen af det samfundsøkonomiske afkast, er de variable omkostninger målt i forhold til omsætningen den største post med mellem $30 \%$ og $37 \%$, lavest for Island og højest for Norge og Storbritannien. Afskrivningerne ligger på 5$14 \%$, dog med den danske fartøjsgruppe oppe på $24 \%$ (jf. tabel 4.1).

De alternative lønomkostninger udviser relativt stor spredning og ligger i intervallet 6-16 \% målt i forhold til landingsværdien (Storbritannien 6 \%, Færøerne $10 \%$, Norge $11 \%$, Danmark $13 \%$ og Island $16 \%$ ). Rækkefølgen afspejler til dels lønniveauet i de 5 lande, som også placerer sig i nævnte rækkefølge. Lønniveauet er dog kun en del af forklaringen på forskellene, idet antal af beskæftigede også spiller en vigtig rolle.

Specielt de lave alternative lønomkostninger i Storbritannien skiller sig ud, og de skyldes først og fremmest den relativt lille arbejdsindsats, der er nødvendig for at opfiske de tildelte makrelkvoter. Der fiskes kun 113 dage pr. år og primært med få fiskedage i det mest givtige fiskeri på makrel. Omkostningerne til arbejdskraft i alternativ anvendelse er generelt lave, hvor der er tale om få store fartøjer og lille mandskab.

Omkostningerne til kapital i alternativ anvendelse varierer også forholdsvis meget, idet de udgør mellem $6 \%$ og $14 \%$ af omsætningen (Island $6 \%$, Færøerne $9 \%$, Danmark $11 \%$, Storbritannien $11 \%$ og Norge $14 \%$ ). Island og Færøerne er sandsynligvis nået længst i bestræbelserne på at sikre et så lille, men samtidig effektivt kapitalapparat som muligt. 
Tabel 4.2. Størrelsen af det samfundsøkonomiske afkast 2007 (type A), mio. DKK og pct. af fangstværdi.

\begin{tabular}{|c|c|c|c|c|c|c|}
\hline & Island & Norge & Færøerne & Danmark & $\begin{array}{r}\text { Stor- } \\
\text { britannien }\end{array}$ & Samlet \\
\hline Aflønning af kapital & 470 & 506 & 146 & 122 & 369 & 1613 \\
\hline Aflønning af arbejdskraft & 335 & 551 & 172 & 167 & 343 & 1568 \\
\hline Total (I) & 805 & 1057 & 318 & 289 & 712 & 3181 \\
\hline Aflønning af kapital i alternativ anvendelse & 77 & 270 & 48 & 79 & 165 & 639 \\
\hline Aflønning af arbejdskraft i alternativ anvendelse & 198 & 228 & 57 & 89 & 90 & 662 \\
\hline Total (II) & 275 & 498 & 105 & 168 & 255 & 1301 \\
\hline Samfundsøkonomisk afkast (=I-II) & 530 & 559 & 213 & 121 & 456 & 1879 \\
\hline - pct. af fangstværdi & $43 \%$ & $28 \%$ & $38 \%$ & $17 \%$ & $32 \%$ & $32 \%$ \\
\hline
\end{tabular}

Forskellene i det samfundsøkonomiske afkast målt i procent af fangstværdien kan delvis forklares med forskelle i forvaltningssystemer. I hele den betragtede periode har Island og Færøerne begge haft veletablerede individuelle omsættelige kvoter og opnår derfor som forventet de højeste samfundsøkonomiske afkast. For Færøerne har dette dog været begrænset til kun at omfatte sild og makrel, men ikke industrifisk, som først er overgået til individuelle omsættelige kvoter i 2009. Herefter følger Storbritannien og Norge, som anvender forvaltningssystemer, hvor kvoteandele er knyttet til fartøjernes licenser. Det må betragtes som mindre effektivt end det førnævnte som følge af mindre fleksibilitet. Til sidst følger den danske fartøjsgruppe, som først fra 2003 gradvist er overgået til individuelle omsættelige kvoter og derfor formentlig ikke endnu har tilpasset kapaciteten og omkostningerne fuldt ud.

Der er desuden en klar tendens til, at fartøjsgrupperne med de største fartøjer udviser det største afkast. På tilsvarende vis spiller det også en rolle, hvad der er af målarter for fiskeriet. Makrelfiskeriet vurderes at være det mest attraktive i den korte sæson. Derefter følger sildefiskeriet, hvoraf den norsk vårgydende sild er den, der giver den bedste kvalitet og pris.

Vender man sig mod landespecifikke forklaringer i de observerede forskelle i det samfundsøkonomiske afkast ses, at den islandske fartøjsgruppe generelt set har lave omkostninger, og desuden er der tale om fartøjer, der effektivt udnytter kapaciteten ved at anvende mange fiskedage om året.

Noget tilsvarende gør sig gældende for den færøske fartøjsgruppe. Den har den største gennemsnitsstørrelse og består af kun 8 fartøjer med et lavt omkostningsniveau, hvilket vurderes at være en væsentlig faktor bag det høje afkast.

For den britiske fartøjsgruppe vurderes, det at det relativt høje samfundsøkonomiske afkast har en væsentlig baggrund i sammensætningen af det britiske fiskeri, hvor makrel dominerer. Denne art vurderes at være det mest attraktive af de her behandlede fiskerier pga. den høje pris samt den relativt lille indsats, der er nødvendig for at opfiske kvoterne i den korte sæson, hvilket afspejler sig i et relativt lille antal fiskedage, der er benyttet. 
Den norske fartøjsgruppe har lidt højere omkostninger end de fire ovennævnte, men fisker på bestande, som for to af de vigtigste bestande - norsk vårgydende sild og blåhvilling - er velforvaltede. Den tredje vigtige bestand er makrel, der som nævnt er et givtigt fiskeri. Disse forhold medvirker til et forholdsvis højt samfundsøkonomisk afkast.

Tabel 4.3. Størrelsen af det samfundsøkonomiske afkast 2007(type B), mio. DKK og pct. af fangstværdi.

\begin{tabular}{|c|c|c|c|c|c|c|}
\hline & Island & Norge & Færøerne & Danmark & $\begin{array}{r}\text { Stor- } \\
\text { britannien }\end{array}$ & Samlet \\
\hline Samfundsøkonomisk afkast (type A) & 530 & 559 & 213 & 121 & 456 & 1879 \\
\hline \multicolumn{7}{|l|}{ Offentlige nettoudgifter: } \\
\hline Tilskud & 0 & -2 & -6 & -12 & -2 & -22 \\
\hline Fiskeriforvaltningsomkostninger & -24 & -115 & -26 & -48 & -83 & -296 \\
\hline Brugerbetaling for forvaltning og kontrol & 1 & 1 & 0 & 0 & 0 & 2 \\
\hline Total & -23 & -116 & -32 & -60 & -85 & -316 \\
\hline - pct. af fangstværdi & $2 \%$ & $6 \%$ & $6 \%$ & $8 \%$ & $6 \%$ & $5 \%$ \\
\hline Samfundsøkonomisk afkast (type B) & 507 & 446 & 181 & 60 & 371 & 1565 \\
\hline - pct. af fangstværdi & $41 \%$ & $22 \%$ & $32 \%$ & $8 \%$ & $26 \%$ & $26 \%$ \\
\hline
\end{tabular}

Den danske fartøjsgruppe har opnået et væsentligt lavere samfundsøkonomisk afkast end de fire ovennævnte lande. En del af forklaringen er de forholdsvis store afskrivninger. En medvirkende årsag er formentligt også, at de danske fartøjer i gennemsnit er væsentligt mindre end de øvrige i dette studie.

Alle de ovennævnte resultater tager udgangspunkt i samfundsøkonomiske afkast uden fradrag for offentlige udgifter til fiskeriet (type A). Herunder i tabel 4.3 er der tilsvarende tal opgjort efter fradrag for offentlige nettoudgifter (type B).

De offentlige nettoudgifter til fiskerisektoren består af tilskud og fiskeriforvaltningsomkostninger med fradrag for brugerbetaling for forvaltning og kontrol. Fordelingerne af offentlige udgifter er foretaget i forhold til landingsværdien for fartøjsgrupperne, hvilket formentlig er en forenkling af de egentlige forhold. Specielt kunne der være en formodning om, at forvaltningsomkostningerne er relativt små for de betragtede fartøjsgrupper, men der findes ikke opgørelser, som giver en nøjagtig fordeling. Brugerbetalingen finder kun sted i Island og Norge og er i begge tilfælde af et begrænset omfang. De årlige tilskud ligger mellem 0 \% for Island og 1,7 \% for Danmark målt i forhold til den samlede landingsværdi.

Fiskeriforvaltningsomkostningerne er langt de største offentlige udgifter til fiskerisektoren og ligger i alle lande væsentlig højere end tilskuddene. Procentvis i relation til landingsværdien er de højest i Danmark med næsten $7 \%$ og lavest i Island med $2 \%$, mens der for de øvrige er tale om et niveau på 5-6 \%. De samlede offentlige nettoudgifter til fiskerisektoren udgør mellem $2 \%$ af landingsværdien i Island og $8 \%$ i Danmark. For de øvrige lande er nettoudgifterne lidt lavere end i Danmark, nemlig $6 \%$. I absolutte tal er der tale om mellem 23 mio. DKK for Island og 116 mio. DKK for Norge. 
Det lave niveau for de offentlige nettoudgifter i Island skiller sig meget tydeligt ud blandt de 5 case studier. Det spiller her en rolle, at der ikke forekommer tilskud, og samtidig foregår der en vis brugerbetaling. Vigtigst er det formentlig, at der i Island er sket en automatisk strukturtilpasning over en længere årrække som en konsekvens af det individuelt omsættelige kvotesystem, som på nærværende tidspunkt har fungeret en del år, hvilket har reduceret eventuel overkapacitet og derigennem behovet for kontrol.

I den anden ende ligger den danske fartøjsgruppe med de højeste offentlige nettoudgifter i forhold til omsætningen delvist som følge at et ekstraordinært højt tilskudsniveau i 2007, men også pga. de højeste forvaltningsomkostninger relativt set. Det andet EU land, Storbritannien, ligger på niveau med de to andre lande, Norge og Færøerne. Det vurderes imidlertid, at EUlandene generelt set har de højeste fiskeriforvaltningsomkostninger grundet den fælles fiskeripolitik. Den gode indtjening i den britiske fartøjsgruppe kan medvirke til at reducere de offentlige nettoudgifter målt i forhold til omsætningen. Færøerne har de næstlaveste forvaltningsomkostninger, men til gengæld er tilskuddene næsthøjest.

Det samfundsøkonomiske afkast efter fradrag af offentlige nettoudgifter til fiskeriet (type B) er højst i den islandske fartøjsgruppe med 507 mio. DKK efterfulgt af fiskeriet i Norge og i Storbritannien på hhv. 446 og 371 mio. DKK. Dernæst følger Færøerne med 181 mio. DKK og Danmark med 60 mio. DKK. Målt i forhold til fangstværdien er rækkefølgen den samme som ved det samfundsøkonomiske afkast type A: Island (41 \%), Færøerne (32\%), Storbritannien (26\%), Norge (22\%) og Danmark (8 \%).

Sammenlignes det samfundsøkonomiske afkast i de denne rapport med de fem fiskerier, der er undersøgt i rapporten „Økonomien i de nordiske fiskerier - Fokus på ressourcerenten“ fra 2006, og som benytter tilsvarende økonomiske antagelser, viste det samfundsøkonomiske afkast efter fradrag for offentlige udgifter til fiskeri at være følgende: Trawlerfiskeriet i Island (28 \%), partrawlerfiskeriet i Færøerne (20\%), kystfiskeriet i Norge (-34 \%), pelagisk fiskeri i Sverige (-20 \%) og muslingefiskeri i Danmark (44\%). Det svenske pelagiske fiskeri ligner de omhandlede case studier mest. Imidlertid skaber det islandske trawlfiskeri og det færøske partrawlerfiskeri et samfundsøkonomisk afkast, som i størrelse kan sammenlignes med her behandlede pelagiske fiskerier. Formodentlig ligger noget af forklaringen i, at der er tale om store fartøjer, der bruger mange fiskedage i løbet af et år. Afkastet i det svenske pelagiske fiskeri var lavt pga. en stor overkapacitet, der skyldtes uhensigtsmæssig forvaltning, mens det norske kystfiskeri var influeret af, at det udføres af mange små fartøjer og var sæsonbetonet. Det danske muslingefiskeri skilte sig særligt positivt ud med et højt samfundsøkonomisk afkast, men det må dog betragtes som et specialfiskeri med særlig lave omkostninger grundet stationære bestande samt ingen væsentlig overkapacitet.

I et norsk studie af Steinshamn (2005) vurderes det, at der i pelagiske fartøjskategorier, der ligner de her behandlede fartøjsgrupper (notfiskerier), er et samfundsøkonomisk afkast (type A) af en størrelsesorden på 38 \% målt i 
forhold til landingsværdien og opgjort ud fra sammenlignelige økonomiske antagelser. Der opnås altså et resultat, der ligger tæt opad de bedste fiskerier i nærværende rapport. Omvendt har man i Sverige for 2004 estimeret det samfundsøkonomiske afkast for gruppen af store pelagiske fartøjer til at være negativ pga. en stor overkapacitet (Paulrud 2004). Tilsvarende for det britiske sildefiskeri i Nordsøen er afkastet for 2006 estimeret til at være negativt (Bjørndal et al. 2010). Det forventes dog samtidigt, at det potentielle afkast kunne være i størrelsen af 65-74 \% af landingsværdien (type A).

I rapporten „The Sunken Billions“ fra Verdensbanken og FAO estimeres det, at ressourcerenten i dag globalt set er negativ. Ved optimal forvaltning af det globale fiskeri vurderes det samtidigt, at man kunne frembringe en ressourcerente i en størrelsesorden af 40-50 \% af landingsværdien. Ud fra en samlet vurdering af de i nærværende rapport estimerede samfundsøkonomiske afkast kan det konkluderes, at de bedste af de fem case studier ligger i den høje ende af det afkast mål i forhold til landingsværdien, som eksisterer i dagens forskellige fiskerier.

Udviklingen i det samfundsøkonomiske afkast i perioden 2000-2008

Det samfundsøkonomiske afkast i procent af landingsværdien er vist i figur 4.1 for perioden 2000-2008 for 4 af case studierne: Danmark, Færøerne, Island og Norge. Det har ikke været muligt at fremskaffe data til beregning af denne tidsserie for Storbritannien. Herforuden er der i figur 4.2 vist det samfundsøkonomiske afkast i løbende priser sammen med landingsværdierne og omkostningerne eksklusiv arbejde og kapital (dvs. landingsværdierne er fratrukket variable omkostninger og afskrivninger). Den alternative aflønning af arbejdskraft og kapital samt de offentlige udgifter til fiskerisektoren er holdt på niveau svarende til 2007 med henblik at kunne se effekten af variationen i de fiskerirelaterede faktorer. Som det fremgår, er der stor variation imellem årene. Der er dog en vis opadgående tendens i alle fire lande. Desuden er der for de fire case studier et mønster, der med et vist forbehold viser et relativt højt samfundsøkonomisk afkast for 2001 og 2002 samt for årene 2005-08. Modsat er det samfundsøkonomiske afkast lavere i årene 2003-04. 
Figur 4.1. Udvikling i det samfundsøkonomiske afkast (type B) 2000-2008, i pct. af fangstværdi.

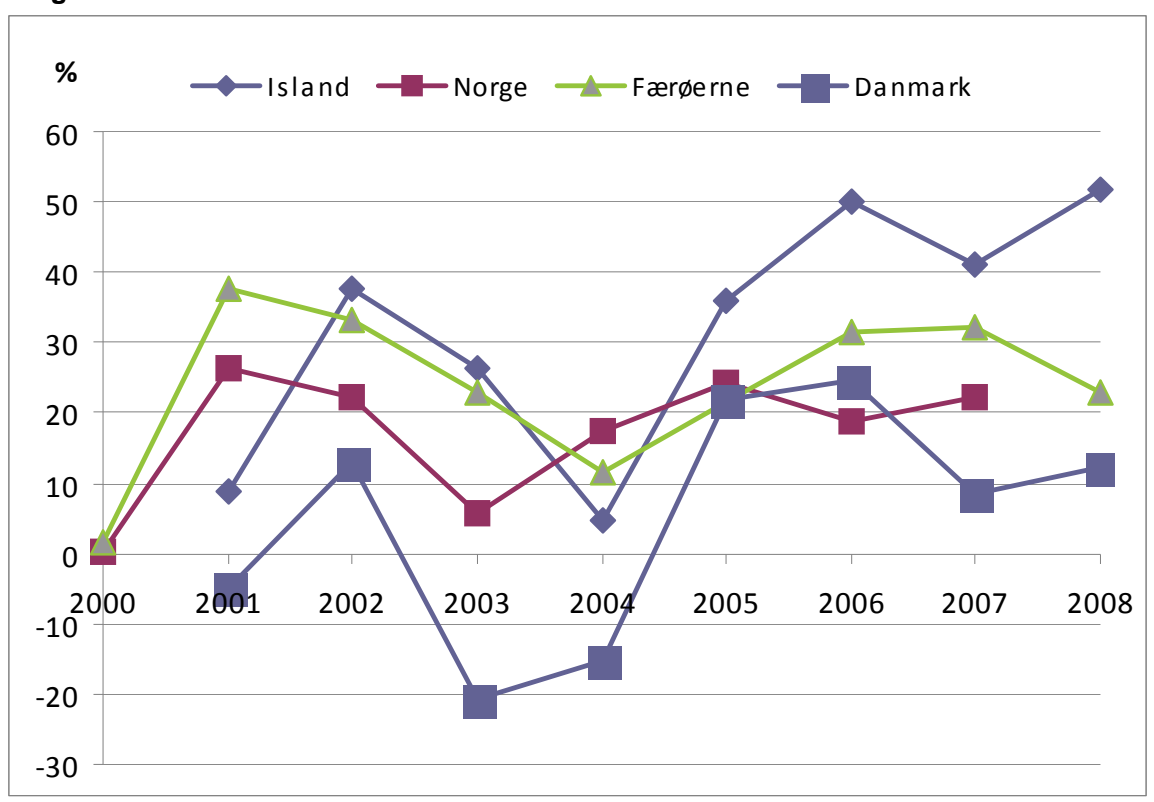

Noter: Det er antaget, at alene fiskerirelaterede data varieres over perioden, hvorimod ikke-fiskerirelaterede data antages konstante på 2007 niveauet. Fiskerirelaterede data inkluderer regnskabsdata, fangstdata, faktisk aflønning af arbejdskraft, beskæftigelse, fiskedage, antal fartøjer og forsikringsværdi og hvor ikke-fiskerirelaterede data indeholder alternativ aflønning af arbejdskraft og kapital og offentlige udgifter til fiskeri.

Ifølge figur 4.1 har Island, Færøerne og Norge på skift det højeste samfundsøkonomiske afkast; dog har Island samlet klaret sig bedst i perioden efterfulgt af Færøerne, og alle tre lande har kun positive samfundsøkonomiske afkast i perioden. Danmark har negativt afkast i 2001, 2003 og 2004. Fartøjsgrupperne i de førstnævnte tre lande har ydermere også mere stabile samfundsøkonomiske afkast, mens de danske fartøjsgrupper udviser væsentlig større udsving, især pga. det store fald i afkastet for 2003 og 2004. Det bør nævnes, at de aktuelle omkostninger til arbejdskraft er højere end de alternative omkostninger til arbejdskraft for alle de fire lande i hele perioden. Tilsvarende gælder for de aktuelle omkostninger til kapital med undtagelse af Danmark for 2003 og 2004 samt Norge for 2000 og 2003, hvilket skyldes det meget lave (negative) afkast i de pågældende år. Når afkastet ændrer sig, ses det, at risikoen er knyttet til kapitalen, mens arbejdskraftens andel er mere stabil.

Figur 4.2 viser, at det samfundsøkonomiske afkast ikke uventet har en meget betydelig sammenhæng med landingsværdiens størrelse. Endvidere ses, at omkostningerne eksklusiv arbejdskraft og kapital overordnet set udviser en forholdsmæssig lille variation over årene. Det samfundsøkonomiske afkast (her type B) følger for alle 4 lande meget nøje det samme variationsmønster som landingsværdien. Medvirkende hertil er, at alternativomkostningerne til aflønning af arbejdskraft og kapital samt de offentlige udgifter er holdt på et niveau svarende til 2007. Det er således helt overvejende ændringer i landingsværdien, der forklarer udsvingene. 
I figur 4.2 er udviklingen i det samfundsøkonomiske afkast af type B 2000-2008 vist i mio. DKK (grøn). Til sammenligning er vist landingsværdi (blå) og omkostninger eksklusiv arbejdskraft og kapital (rød).

Figur 4.2. Udvikling i det samfundsøkonomiske afkast (type B), landingsværdi og omkostninger eksklusiv arbejdskraft og kapital, 2000-2008, i mio. DKK.
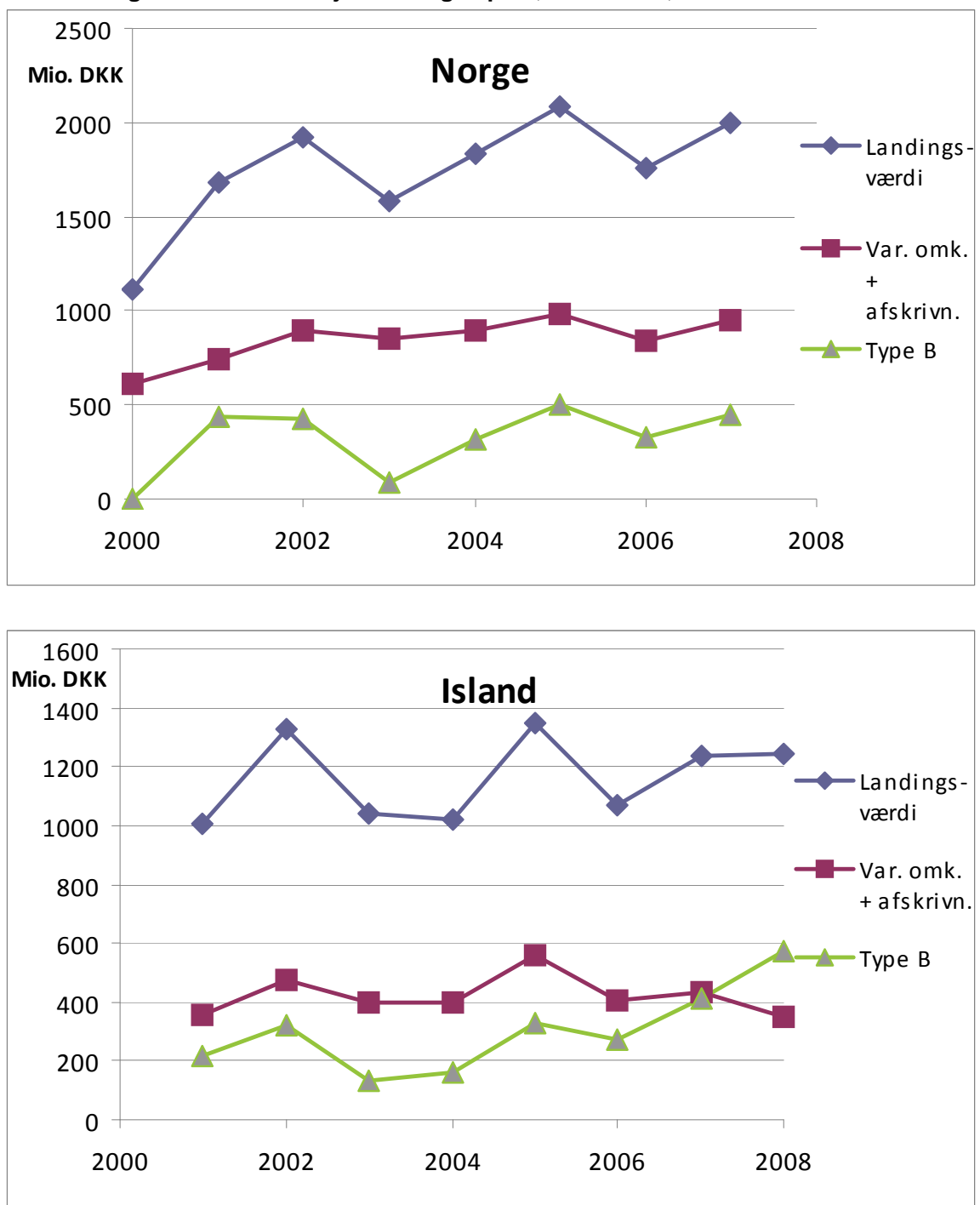

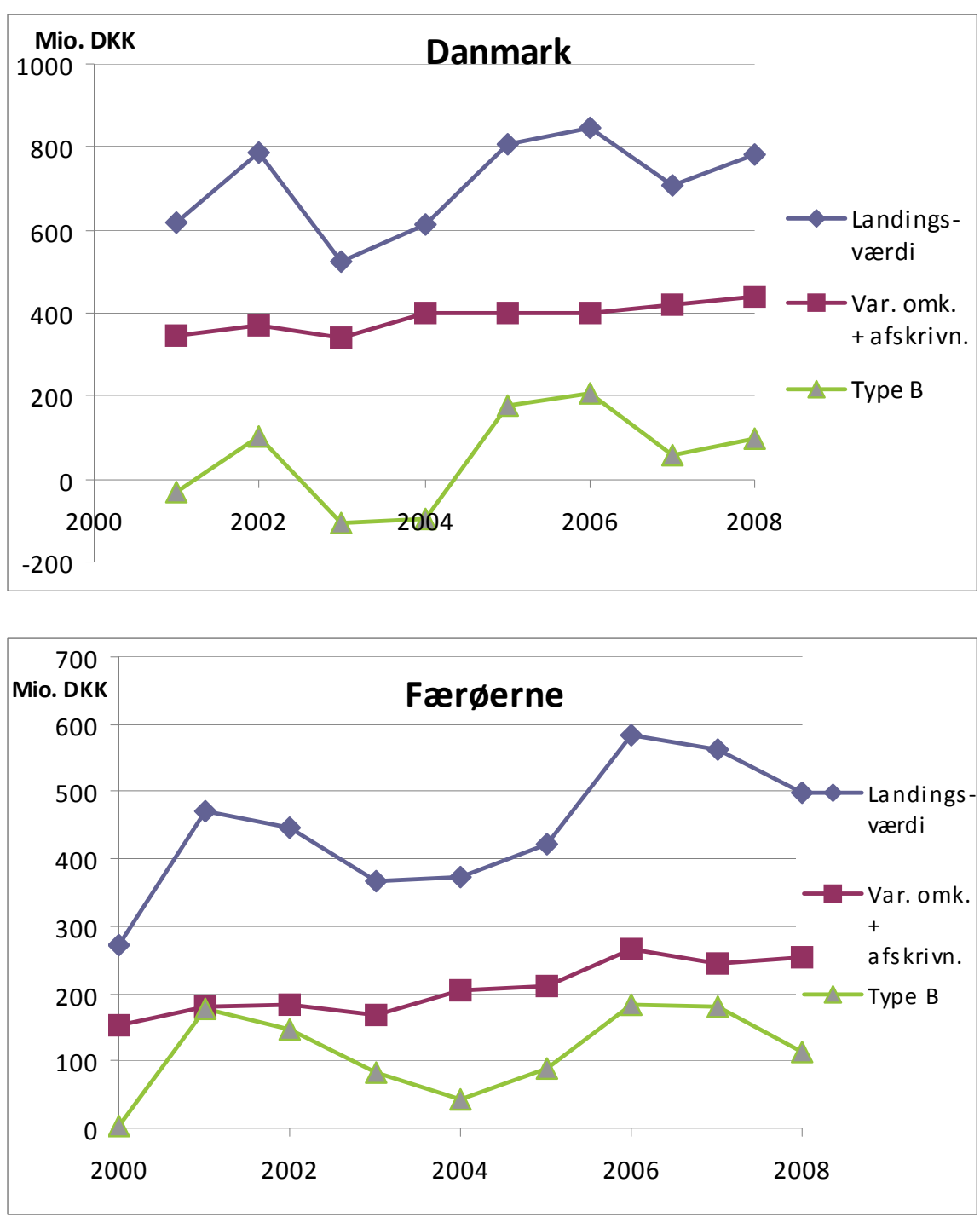

Årsagen til variationen skal hovedsagelig søges i prisudviklingen samt i fluktuationer i de landede mængder. Disse mængder bestemmes af de fastsatte kvoter, som igen er afhængige af forvaltningen. Det gennemsnitlige samfundsøkonomiske afkast for den betragtede periode er højest for den islandske fartøjsgruppe med et gennemsnit på 385 mio. DKK, dernæst følger den norske fartøjsgruppe med 320 mio. DKK og efterfulgt af den færøske fartøjsgruppe på 114 mio. DKK. Den danske fartøjsgruppe har i gennemsnit genereret et samfundsøkonomisk afkast på 52 mio. DKK.

Spørgsmålet er, om der i nærværende analyse kan ses resultater af forskellig forvaltning samt effekter af en udvikling i forvaltningssystemerne. Individuelle kvoter har som konsekvens, at fiskerirettighederne til den fælles fiskeressource fordeles ud på fiskerne. Individuelle kvoter og især individuelle omsættelige kvoter er et instrument til opnåelse af økonomisk effektivitet i fiskeriet. Individuelle omsættelige kvoter giver fiskerne bedre mulighed for at planlægge og udøve et effektivt fiskeri. Overgang til individuelle om- 
sættelige kvoter giver nogle ekstra fordele, da fiskerne kan foretage yderligere tilpasninger ved at handle kvoter med hinanden. Herved forventes det, at omkostningerne reduceres, idet de mest effektive fiskere formodes gradvist at opkøbe kvoterne, og overkapacitet vil forsvinde. Imidlertid er det kun det danske pelagiske fiskeri, som i perioden har undergået forandringer med hensyn til omsætteligheden af fiskekvoterne med den gradvise introduktion af individuelt omsættelige kvoter fra 2003, mens Island og i overvejende grad også Færøerne (sild og makrel) allerede havde omsættelige kvoter eller for Norges vedkommende et system der må betragtes som lidt mindre effektivt. Med hensyn til den danske fartøjsgruppe er der siden 2003 sket en gradvis reduktion af fartøjsomkostningerne og andre løbende omkostninger, mens brændstofudgifterne varierer, først og fremmest på grund af udefrakommende ændringer i brændstofpriserne med en tendens i opadgående retning. Afskrivningerne er nogenlunde konstante bortset fra de sidste to år 2007 og 2008, i hvilke de er ekstraordinært store. Omkostningerne til kapital i alternativ anvendelse har været ret stabile, mens omkostningerne til arbejdskraft i alternativ anvendelse er faldet målt i forhold til landingsværdien siden 2003-2004. Det skyldes, at antallet af beskæftigede i fartøjsgruppen er næsten blevet halveret i delperioden fra 2003 til 2008. Ud fra en samlet betragtning må man konkludere, at der i den danske fartøjsgruppe er foregået visse effektiviseringstiltag, som gradvist har reduceret noget af overkapaciteten og forøget effektiviteten og derved formentlig også øget det samfundsøkonomiske afkast. Denne tendens overskygges dog klart af udsvingene i priser og landingsmængder. Effektiviseringstiltagene vurderes at fortsætte efter 2007.

For de øvrige tre lande - Island, Færøerne og Norge - ses der ingen markante udviklingstendenser i omkostningerne. Der ses udsving i de variable omkostninger især brændstofudgifterne, men samlet set over hele perioden ligger de variable omkostninger på et forholdsvist konstant niveau. Tilsvarende ligger også afskrivningerne og alternativomkostningerne for kapital også på et relativt stabilt niveau i hele perioden. Omkostninger til arbejdskraft i alternativ anvendelse har haft en svagt faldende tendens i de tre lande, hvilket skyldes en faldende beskæftigelse, som dog er mindre end for den danske fartøjsgruppe. Der er således i god overensstemmelse med det forhold, at de forvaltningsmæssige betingelser i disse tre lande har været uforandrede og uden markante udviklingstræk med hensyn til omkostningssiden for de tre lande i perioden. Samlet set vurderes det, at Island efterfulgt af Færøerne har opnået de højeste niveauer for det samfundsøkonomiske afkast. Norge følger efter med et mindre effektivt og fleksibelt system, og lavest af de fire lande placerer Danmark sig, der dog på baggrund af indførelsen af en mere effektiv forvaltning gradvist forventes at kunne skabe et højere samfundsøkonomisk afkast.

Den væsentligste forklaring på udsvingene i det samfundsøkonomiske afkast er som tidligere nævnt variationen i landingsværdien, der er en konsekvens af fluktuationer i fangstmængderne samt i prisudviklingen. Prisdan- 
nelsen på de tre produkter, sild, makrel og industrifisk, bestemmes af udbud og efterspørgsel, og priserne dannes på et integreret internationalt marked og for industrifisk på et verdensmarked. For sild er norsk vårgydende sild prissættende. Silden afsættes næsten udelukkende i Nord- og Østeuropa samt i det tidligere Sovjetunionen. Kursen på den russiske rubel spiller derfor også en vigtig rolle. Makrel afsættes tilsvarende i Nord- og Østeuropa samt i Østasien, hvor Japan er den vigtigste aftager. For industrifisk dannes prisen på fiskemel og -olie som nævnt på et verdensmarked, og prisen fastsættes i dollar. Peru er den vigtigste producent, og fænomenet El Niño spiller en stor rolle, da fangsterne falder kraftigt i år med El Niño. Efterspørgslen efter fiskemel og olie kommer især fra akvakultur, som er vokset meget kraftigt i gennem de senere år.

Figur 4.3 viser de observerede priser på sild, makrel og industrifisk for de involverede fartøjsgrupper. Priserne på hver af de tre arter har et næsten identisk forløb i alle landene, hvilket understreger, at priserne dannes på et integreret internationalt marked eller på et verdensmarked. Der er lidt større forskelle på priserne for sild og industrifisk end makrel, delvis begrundet i, at der er pris- og kvalitetsforskelle på sild fra de to bestande samt forskelle i pris på de forskellige industriarter.

Priserne på sild og makrel fulgte nogenlunde det samme mønster med en stigning i starten af perioden, et fald i 2003 og efterfølgende stigning med top i 2005. Makrelpriserne steg meget kraftigt i 2005 som følge af kombinationen af et mindre udbud og en stigende efterspørgsel. For sildepriserne ses en stigning i 2001-02 efterfulgt af et kraftigt fald i 2003, hvorpå den steg på ny. Baggrunden for dette forløb er, at en kombination af mindre udbud, stigende efterspørgsel i Rusland og Østeuropa samt højere kurs på rublen gav kraftig stigende pris frem til 2002, som viste sig at være urealistisk høj. En korrektion af prisen samt øgede sildekvoter resulterede i prisfald i 2003-04. En styrkelse af rublen og forøget købekraft i Rusland og Østeuropa resulterede på ny i højere priser i 2005 - især for norsk vårgydende sild, som afsættes hertil. Prisudviklingen forløber lidt anderledes for industrifisk, hvor priserne lå relativt konstant frem til 2005, hvorefter der sås stigninger frem til 2007. Det omtalte fænomen El Niño samt euro-dollar kursen spillede en stor rolle i udviklingen af de observerede prisstigninger.

Den beskrevne prisudvikling forklarer i høj grad sammen med de landespecifikke ændringer i fangstmængder de iagttagne variationer i det samfundsøkonomiske afkast. For de danske fartøjsgrupper sås lavt afkast i 2001, 2003 og 2004 samt i mindre grad i 2007. Udover de lave priser på sild og makrel var industrifiskeriet i Danmark på et meget lavt niveau i de tre år 2003, 2004 og 2005 forårsaget af et fejlslagent tobisfiskeri. Mindre fald i både pris og mængder ligger bag det mere beskedne dyk i det samfundsøkonomiske afkast for 2007. 
Figur 4.3. Realiserede priser på sild, makrel og industrifisk for de behandlede fartøjsgrupper i perioden.
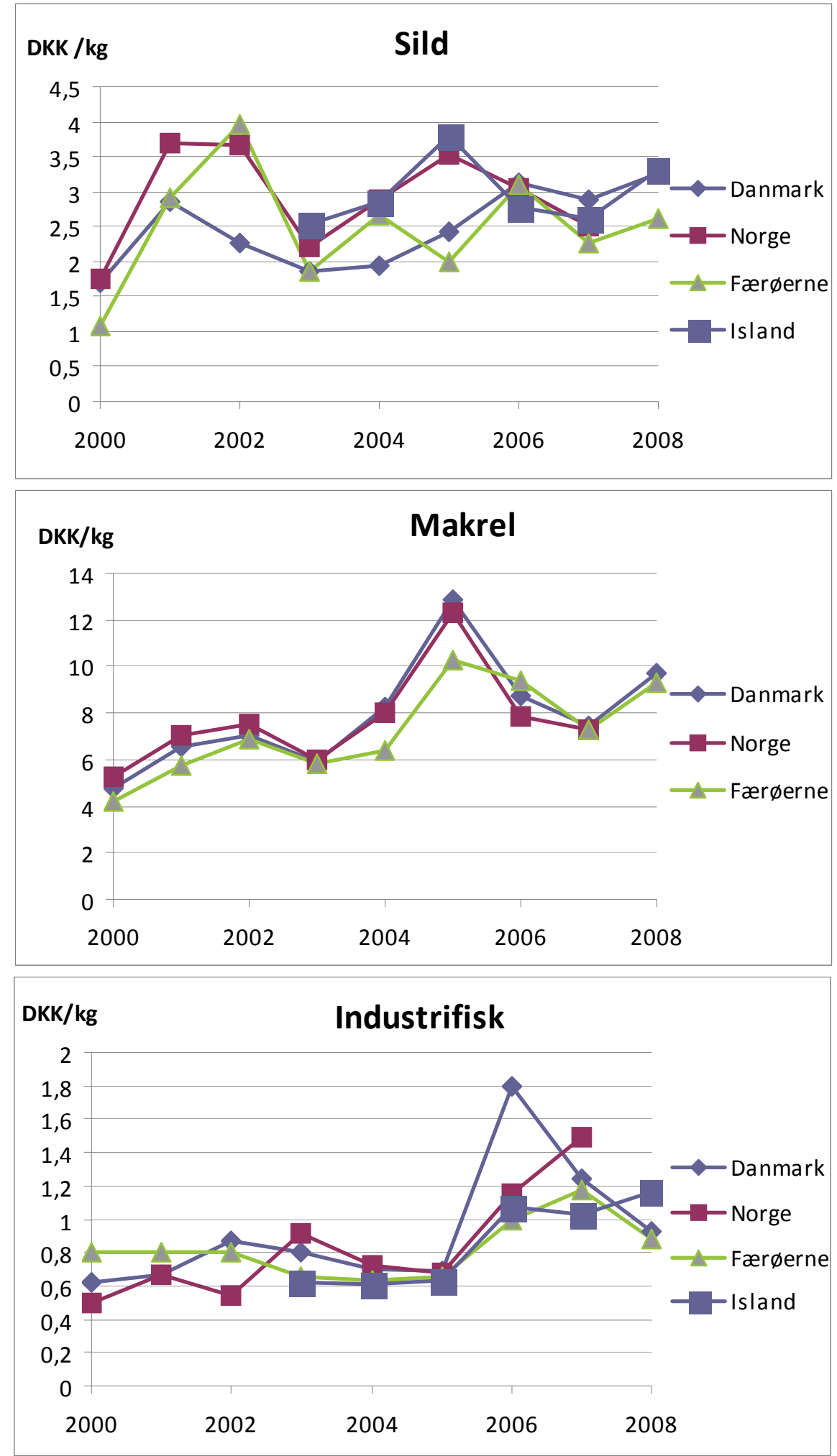

Note: For Island er der ikke data for årene før 2003.

Kilde: Landingsstatistik (Statistics Iceland (a), Norges Sildesalgslag, Færøernes Statistiske kontor, Fiskeridirektoratet i

Danmark og STECF). 
For de norske fartøjsgrupper ses ingen væsentlige fald i landingsværdien udover faldet i 2003 med baggrund i prisfald på sild og makrel og et lidt mindre fald i 2006, der skyldes lavere fangster af industriarter og lidt lavere priser på sild og makrel. Det samfundsøkonomiske afkast udviser derfor heller ikke så kraftige udsving, som tilfældet er for Danmark og Færøerne. Prisfaldet på sild og makrel i 2003 blev for Norges vedkommende i nogen grad opvejet af mindre prisstigning på industrifisk og øgede mængder. Tilsvarende er faldende fangstmængder af industrifisk fra 2005 og fremefter opvejet af øgede mængder sild og generelt højere priser.

For Færøerne udviser fangstmængderne et stabilt forløb, men der sker en forskydning i artssammensætningen i fangsterne imod en større andel blåhvilling midt i den betragtede periode, hvilket giver lavere gennemsnitspriser. Dette forhold forklarer sammen med de generelt ugunstige prisforhold i 2003 og 2004 de relativt lave samfundsøkonomiske afkast fra 2002 til og med 2005.

For Island har det kun været muligt at opgøre fangster og fangstværdi for arterne særskilt fra 2003 og frem. Det samfundsøkonomiske afkast er relativ lavt i 2003 og 2004 begrundet i tilsvarende lave landingsværdier. Det samfundsøkonomiske afkast har været jævnt stigende siden 2003. Den bagved liggende fangstsammensætning har dog varieret væsentligt, idet industrifangsterne blev reduceret kraftigt fra 2003 til 2006 pga. et svigtende loddefiskeri, mens denne effekt til gengæld er blevet modvirket af højere priser samt en øget sildefangst i 2005.

\subsection{Det maksimale samfundsøkonomiske afkast}

Det maksimale samfundsøkonomiske afkast er defineret som „det årlige maksimale overskud der på lang sigt er tilbage efter aflønning af kapital og arbejdskraft svarende til, hvad der opnås i andre erhverv“. Det maksimale samfundsøkonomiske afkast angiver således det ekstra overskud, der hvert år ud i al fremtid er tilbage efter, at arbejdskraft og kapital har opnået en aflønning på niveau med, hvad der opnås i andre erhverv. Det maksimale samfundsøkonomiske afkast identificeres som type A, dvs. før fradrag af offentlige nettoudgifter til fiskeriet.

Et stort samfundsøkonomisk afkast er ud fra en snæver langsigtet økonomisk betragtning ønskelig, men størrelsen af det samfundsøkonomiske afkast skal ses i sammenhæng de generelle fiskeripolitiske målsætninger relateret til beskæftigelse, regionalpolitik og flådestruktur. Dette diskuteres nærmere i afsnit 4.3.

I nærværende afsnit vurderes ikke, hvilke politiske målsætninger der bør prioriteres; der beregnes alene, hvor stort et samfundsøkonomisk afkast der kan opnås, såfremt der føres en fiskeripolitik, der alene tilstræber at opnå det maksimale samfundsøkonomiske afkast, og som ikke inddrager andre mål i fiskeripolitikken. 
Det maksimale samfundsøkonomiske afkast er endvidere pr. definition beregnet som holdbar på lang sigt, men opnåelse af det maksimale samfundsøkonomiske afkast på lang sigt vil typisk indebære, at der skal opgives noget på kort sigt. Dette forhold inddrages ikke i analysen. Dvs. det maksimale samfundsøkonomiske afkast identificeres på lang sigt uden at analysere overgangsperioden fra den nuværende situation til en situation, hvor det maksimale samfundsøkonomiske afkast er opnået. Identifikationen af det maksimale samfundsøkonomiske afkast er således alene en angivelse af det $ø$ øonomiske potentiale i det pelagiske fiskeri i den Nordøstlige del af Atlanterhavet.

\section{Beregningsmetode}

Det maksimale samfundsøkonomiske afkast beregnes i en bio-økonomisk model på grundlag af en lang række simplificerende forudsætninger. Dette indebærer, at der er stor usikkerhed på beregningerne. Det maksimale samfundsøkonomiske afkast giver en indikation af det økonomiske potentiale, men kan ikke beregnes præcist. Det tekniske grundlag for modellen er gennemgået $\mathrm{i}$ bilag 1.

Ideen i beregningen er, at det maksimale samfundsøkonomiske afkast bestemmes ved den fiskeriindsats, målt ved antal fiskedage, som giver den største vedvarende forskel mellem omsætning og omkostninger. Omsætningen bestemmes med de gældende priser og af fangsterne, som på lang sigt stiger med fiskeriindsatsen indtil et vist niveau, hvorefter de falder (jf. figur B1). Årsagen til faldet er, at fiskes der meget, vil der opstå overfiskeri, hvor det på lang sigt ikke er muligt at opretholde samme fangstniveau. Omkostningerne stiger med fiskeriindsatsen, idet det er dyrere at fiske, jo mere der fiskes. Det antal fartøjer, der er nødvendige for at opnå det maksimale samfundsøkonomiske afkast, findes ud fra det totale antal fiskedage. Ideen i beregningen er skitseret grafisk i nedenstående boks 4.1.

\section{Boks 4.1 Bestemmelse af det maksimale samfundsøkonomiske afkast.}

Det maksimale samfundsøkonomiske afkast bestemmes, hvor forskellen mellem indtægter og omkostninger i fiskeriet ved en bestemt fiskeriindsats er størst. Fiskeriindsatsen måles ved det totale antal fiskedage i fartøjsgruppen om året.

Omsætningen er stigende med stigende fiskeriindsats, idet der fanges, mere jo mere der fiskes, så længe bestanden ikke biologisk overfiskes. Stiger fiskeriindsatsen tilstrækkeligt meget, vil fangsterne falde. Årsagen er, at fiskebestandene ikke har tid til at genetablere sig i samme omfang efter intensivt fiskeri, hvilket medfører, at fangstmængderne og dermed omsætningen falder.

De totale omkostninger er stigende med stigende fiskeriindsats, idet det er dyrere at fiske jo flere fartøjer og dermed fiskedage, der anvendes. Samtidig er de gennemsnitlige omkostninger stigende med stigende fiskeriindsats bl.a. som følge af, at nogle fiskere er mere effektive end andre. 
Det eksisterende samfundsøkonomiske afkast er i figuren angivet som $\mathrm{R}_{0}$, hvor det større maksimale samfundsøkonomiske afkast er angivet, der hvor forskellen mellem total omsætning og totale omkostninger er størst $\left(\mathrm{R}_{\max }\right)$.

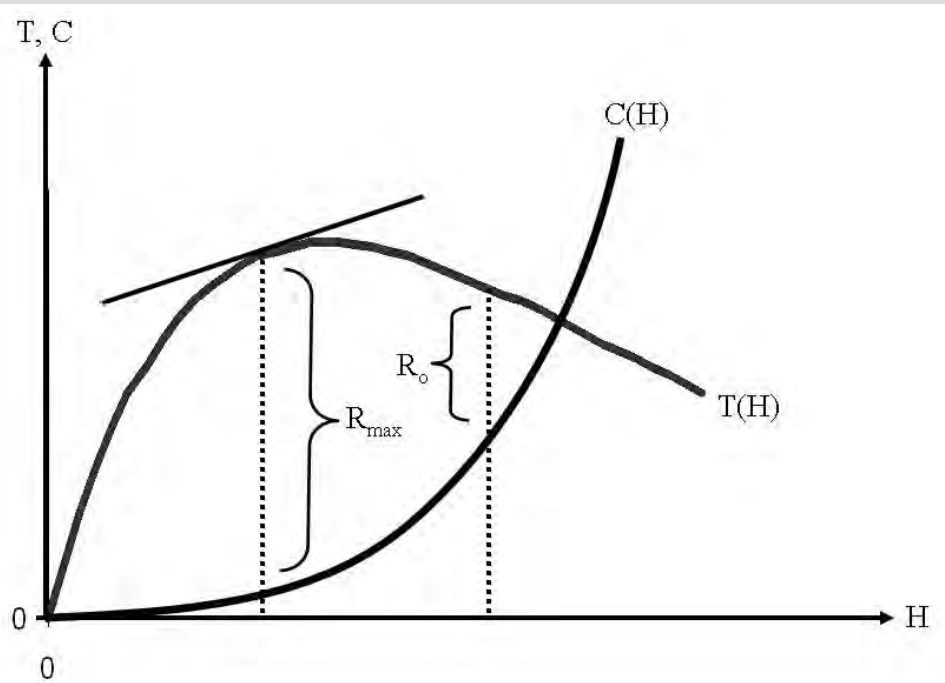

Figur B1. Totale omkostninger og omsætning som funktion af antal fiskedage.

Da fartøjsgrupperne fisker på flere arter og bestande, er det summen af indtægterne fra fangst af de forskellige bestande som bruges i beregningerne. Det antages derfor, at hver fartøjgruppes relative tidsforbrug på de forskellige bestande er konstant. Figur B2 illustrerer under disse forudsætninger, hvordan omsætningen fra de forskellige bestande ændres når antal fiskedage ændres.

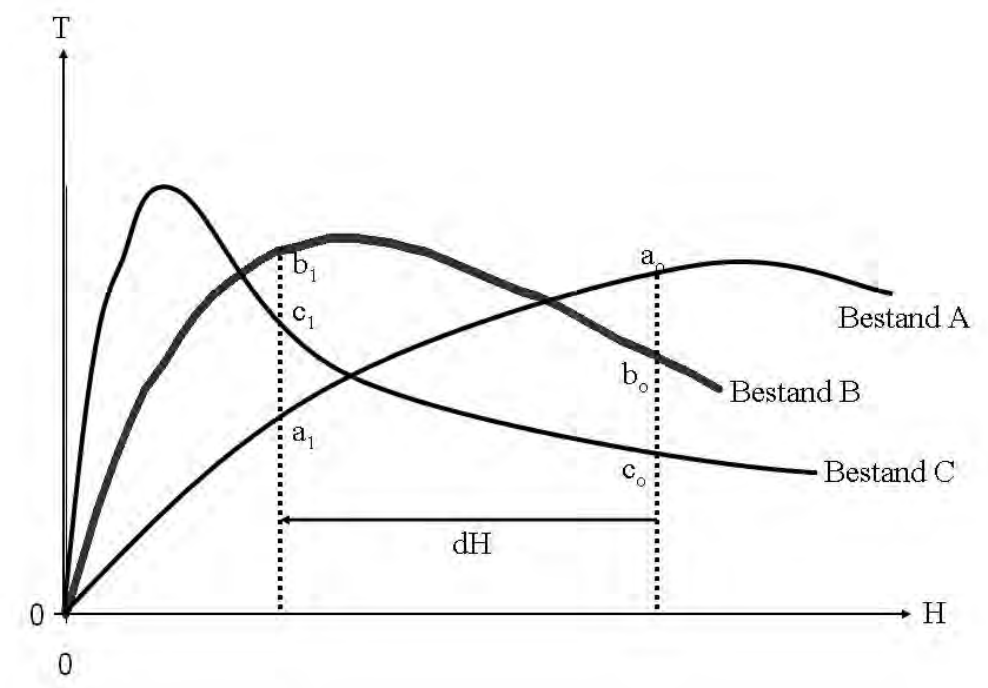

Figur B2. Nuvœrende og æendret samfundsøkonomisk afkast i flerartsfiskerier ved cendret fiskeriindsats.

Idet de enkelte fartøjgrupper fisker på de samme bestande for hvilke der løbende aftales fordeling af totalkvoter mellem de berørte lande, antages det først, at hver national fartøjsgruppe højst kan fange deres andel af totalkvoten. Derefter antages alternativt at individuelle fartøjer fra forskellige lande kan handle kvoter med hinanden, hvorved der ikke er nationale kvoter, men kun totalkvoter for alle fartøjsgrupper. 
Beregningen baseres på en bio-økonomisk model som er en revideret version af EIAA modellen (SEC 2004). EIAA står for Economic Interpretation of ACFM Advice, og modellen anvendes til vurdering af de økonomiske konsekvenser af at gennemføre det Internationale Havforskningsråds biologiske rådgivning i den årlige kvotefastsættelse i EU. Ideen i modellen er at anvende biologiske bestands- og kvoteestimater i samspil med økonomiske informationer på variable og faste omkostninger. Med givne fangstmuligheder og bestandsstørrelser beregner modellen de lavest mulige omkostninger for at fange den givne mængde. Herigennem bestemmes overskud og samfundsøkonomisk afkast.

EIAA modellen anvendes normalt primært for det korte sigt til vurdering af næste års kvoter, hvor beregningen af det maksimale samfundsøkonomiske afkast i nærværende afsnit er for det lange sigt. Derfor har det været nødvendigt at udvide modellen på nogle områder. For det første er biologi inddraget mere eksplicit ved, at størrelsen af gydebiomassen bestemmer fangsterne på lang sigt og under antagelse af, at fiskeridødeligheden i udgangssituationen er bæredygtig. Det samfundsøkonomiske afkast beregnet i denne model, fortolkes så efterfølgende i forhold til denne antagelse. Er antagelsen realistisk, er beregningen af det samfundsøkonomiske afkasts størrelse rimelig. Er fiskeridødeligheden i udgangssituationen derimod ikke bæredygtig, er der risiko for fremtidige reduktioner i rekruttering og bestand, hvilket kan indebære, at det samfundsøkonomiske afkast på lang sigt vil falde.

For det andet er omkostningsberegningen baseret på, at alle omkostninger er variable, da modellen analyserer det lange sigt. For det tredje afhænger omkostningerne alene af fiskeriindsatsen, da der herigennem opstår mulighed for at indbygge i modellen, at nogle fiskere er mere effektive end andre eller har lavere alternative beskæftigelses- og indtægtsmuligheder.

Beregningen baseres på en lang række simplificerende forudsætninger, som teknisk er gennemgået i bilaget. Disse er:

1. Uændret flådestruktur.

2. Uændret fiskerimønster.

3. Den gydebiomasse, der giver de størst mulige vedvarende fangster, bestemmes ved forsigtighedsprincippet.

4. Fiskeridødeligheden i dag er bæredygtig.

5. Bestandssituationen for bestande, hvor biologiske informationer er mangelfulde, følger situationen i bestande, hvor biologien er kendt.

6. Fordelingen af totalkvoten mellem de nationale fartøjsgrupper er uændret.

7. Den maksimale kapacitetsudnyttelse er 350 dage i Island, 300 på Færøerne og 250 dage i de øvrige lande.

8. Mulighed for alternativ beskæftigelse foreligger.

9. Prisen på fisk er konstant 
Uændret flådestruktur indebærer, at nuværende størrelse og type af fartøjer også vil være fremtidens sammensætning af flåden, og uændret fiskerimønster indebærer, at de enkelte fartøjsgruppers relative tidsforbrug på de forskellige bestande er konstant. Antagelsen om uændret fiskerimønster indebærer, at der i beregningerne er antaget, at en fast andel af fangsterne fra hver bestand går til industrifisk. Blåhvilling, tobis og lodde er antaget udelukkende at gå til industri, hvor makrel går udelukkende til konsum. Sild går primært til konsum, men en mindre andel går til industri. Det undersøges således ikke i denne rapport, om det vil være økonomisk fordelagtigt at omlægge fra industri- til konsumfiskeri.

Den konstante pris på fisk indebærer, at ændret udbud ikke påvirker prisen, hvilket vurderes rimeligt, da priser på de fleste fiskearter dannes på verdensmarkedet. Beregningen baseres alene på viden om de bestande, der haves biologiske vurderinger af. Resultaterne er mere pålidelige, jo mindre den ukendte udnyttelsesgrad er. Andelen af bestande, hvor udnyttelsesgraden er ukendt, er angivet i tabel 3.3. Den konstante pris indebærer endvidere, at der i beregningen ses bort fra, at bedre fiskeriforvaltning kan medføre, at udbuddet stiger, og priserne derved falder. Antagelsen om at prisen er uafhængig af udbuddet i det konkrete fiskeri vurderes dog realistisk, idet priserne på de fleste arter bestemmes på et verdensmarked. Den konstante pris indebærer imidlertid også, at der ses bort fra, at bedre fiskeriforvaltning kan medføre, at der fanges større fisk, som normalt giver højere kilopris.

Den uændrede fordeling af totalkvoten mellem lande skal dels ses i sammenhæng med at de nationale fartøjsgrupper fra de forskellige lande fisker på mange af de samme bestande, dels i sammenhæng med at totalkvoter og fordeling heraf aftales mellem landene. Forudsætningen for, at muligheden for alternativ beskæftigelse foreligger, indebærer, at fiskere kan finde andet arbejde på land svarende til gennemsnitslønnen.

Biologien inddrages i beregningen gennem den gydebiomasse, som giver det største biologiske udbytte (MSY) på lang sigt. Denne antages bestemt af forsigtighedsprincippet. Herudover inddrages biologien gennem antagelse af, at fiskeridødeligheden er bæredygtig, hvor det beregnede samfundsøkonomiske afkast fortolkes i forhold til rimeligheden af denne antagelse. Er antagelsen rimelig, er størrelsen af det samfundsøkonomiske afkast realistisk, men ellers er der risiko for, at den er overvurderet på lang sigt. Ses eksempelvis for makrel er gydebiomasse 2,5 mio. tons (2007), hvor den gydebiomasse, der skaber det størs mulige langsigtede fangst, er 2,3 mio. tons. Dette indebærer, at gydebiomassen er på et bæredygtigt niveau. Derimod er fiskeridødeligheden højere end anbefalet (ICES 2008), hvilket indebærer, at der er forøget risiko for rekrutteringssvigt. Konsekvensen er risiko for, at den beregnede maksimale samfundsøkonomiske afkast er overvurderet.

Økonomi inddrages i beregningen, som beskrevet i afsnit 4.1.1, tilføjet antagelsen om konstante priser, og at totale omkostninger stiger med fiskeriindsatsen.

Analysen er foretaget med udgangspunkt i fem konkrete fartøjsgrupper, som repræsenterer dele af de tilsvarende nationale fartøjsgrupper. For Færøerne og 
Storbritannien er dette ikke et problem, fordi de i analysen anvendte fartøjsgrupper omfatter hovedparten af landenes totalkvoter (total allowable catch, TAC). Modsat for Norge varierer fangsten for fartøjsgruppen, der anvendes i analysen, mellem $52 \%$ og $100 \%$ af de norske TAC'ere. De resterende dele af de norske kvoter fanges af mindre pelagiske trawlere og kystfartøjer, som vurderes at have en lavere rentabilitet pr. kg fangst. Også i Danmark er der mindre fartøjer med en formodet lavere rentabilitet, der fisker på de pågældende pelagiske arter. Det nuværende samfundsøkonomiske afkast for Norge og Danmark vil således være overvurderet, ligesom estimaterne for en optimal forvaltning, såfremt den nuværende flådestruktur forbliver, som de er. Et tilsvarende forhold opstår i Island. Fartøjsgruppen er opdelt efter størrelse, og de pelagiske fartøjer er grupperet med andre fartøjer af tilsvarende størrelse. Omkostningsoplysningerne kan derfor overvurdere de faktiske driftsomkostninger.

Som følge af, at makrelfiskeriet vurderes at være det økonomisk vigtigste, og med en sæson på kun 3-4 måneder, samt som følge af at industrifiskeriet i almindelighed kan være økonomisk mindst givtigt, er det ikke sikkert, det kan betale sig at fiske alle industrifiskearter. Sæsonbetonet industrifiskeri efter eksempelvis tobis kan dog i gode år være meget rentabelt. Derfor maksimeres med to forskellige antagelser om antal fiskedage pr. år. To scenarier er beskrevet $\mathrm{i}$ boks 4.2. For begge scenarier antages det, at fangstsammensætningen pr. fiskedag er konstant i de nationale fartøjsgrupper. Denne antagelse er nødvendig, fordi regnskabsdata kun eksisterer offentligt tilgængeligt i samlet form for hele år, og omkostninger for fiskeri på enkeltarter ikke kendes. Konsekvensen er, at det maksimale samfundsøkonomiske afkast kan være undervurderet.

\section{Boks 4.2. Scenarier for maksimering af det samfundsøkonomiske afkast.}

Det samfundsøkonomiske afkast maksimeres i to alternative scenarier i forhold til det mulige antal af fiskedage.

Scenarie 1: Det maksimale antal dage, et fartøj kan fiske om året, antages at være det gennemsnitlige antal dage, fartøjsgruppen fiskede i 2007. Dette er fx for den norske fartøjsggruppe 206 dage (jf. tabel 3.1).

Scenarie 2: Det maksimale antal dage, et fartøj kan fiske om året, antages at være 350 dage for islandske fartøjer, 300 for færøske og 250 for norske, danske og britiske fartøjer.

Eneste forskel mellem scenarie 1 og 2 er, at der vil blive brugt færre fartøjer i scenarie 2 end 1 . Det samfundsøkonomiske afkast beregnes i begge scenarier under to alternative antagelser. Først antages, at fordelingen af totalkvoter mellem de forskellige nationale fartøjsgrupper er stabil, og derefter at fordelingen kan ændres. Den første antagelse svarer til, at fartøjer fra forskellige lande ikke kan handle fiskerirettigheder med hinanden. Den anden antagelse svarer til, at fartøjer fra alle lande individuelt kan handle fiskerirettigheder med hinanden. Dette vil på lang sigt indebære at effektive fartøjer alt andet lige vil opkøbe kvote fra de mindre effektive fartøjer, uanset nationalitet.

Endelig maksimeres både under antagelse af, at kvoter kun kan sælges mellem fartøjer nationalt, dels at de kan sælges mellem lande. National maksimering 
svarer til en situation, hvor der forvaltes bedst muligt, givet at den betragtede fartøjsgruppe (og hvert land) har en fast andel af totalkvoterne og bestande. Dette kan, jf. teorien, fx opnås ved tilstedeværelse af individuelt nationalt omsættelige fiskerirettigheder. International maksimering kan fx opnås ved at gøre de individuelle kvoter omsættelige mellem fartøjer fra forskellige lande uden bindinger. Det er for sådanne forvaltningssystemer, at det maksimale samfundsøkonomiske afkast er identificeret i de gennemførte analyser.

Data

Økonomiske data er beskrevet i afsnit 4.1.2. Biologiske data kendes fra det Internationale Havforskningsråd (ICES), som årligt rådgiver om fiskeriforvaltningen for de vigtigste bestande i det nordøstlige Atlanterhav, samt fra det islandske havforskningsinstitut (lodde). De biologiske data, der anvendes, er faktisk gydebiomasse og den gydebiomasse, der giver de maksimale vedvarende fangster, samt faktiske fangster (tabel 3.5). Den gydebiomasse, der giver de størst mulige fangster på lang sigt, bestemmes af forsigtighedsprincippet. ICES fastsætter ved anvendelse af dette princip årligt det niveau for gydebiomassen, der giver den størst mulige sikkerhed for fremtidige fangster.

Forudsat, at vi er i ligevægt i den nuværende situation (2007), dvs. at fiskeriindsatsen er bæredygtig, vil en gydebiomasse mindre end den, der giver den maksimale fangst, indebære, at fangsterne på lang sigt kan forøges ved at reducere fiskerindsatsen. Det samfundsøkonomiske afkast kan derved forøges. Det maksimale samfundsøkonomiske afkast opnås dog ikke nødvendigvis ved den fiskeriindsats, der giver de størst mulige vedvarende fangster, men der hvor forskellen mellem omkostninger og indtægter er størst (jf. boks 4.1). Det kan under normale forudsætninger i et fiskeri på en art vises at være ved en fiskeriindsats, der er mindre end den, der giver den maksimale vedvarende fangst.

Såfremt vi ikke er i ligevægt i den nuværende situation, vil det samfundsøkonomiske afkast være upræcist beregnet. Hvis fiskeriet (fiskeridødeligheden) ikke er bæredygtigt, er der risiko for, at rekrutteringen svigter, hvilket kan medføre, at det maksimale samfundsøkonomiske afkast er overvurderet. Hvis fiskeriet er bæredygtigt, er denne risiko minimal, og det samfundsøkonomiske afkast nogenlunde præcist beregnet.

\section{Resultater}

Ved anvendelse af data og metode beskrevet ovenstående beregnes det maksimale samfundsøkonomiske afkast, som angivet i tabellerne 4.4-4.6. Landingsværdien og det samfundsøkonomiske afkast i 2007 er angivet til sammenligning. 
Tabel 4.4. Det maksimale samfundsøkonomiske afkast (type A) ved fast for deling af kvoter mellem lande.

\begin{tabular}{|c|c|c|c|c|c|c|}
\hline & Island & Norge & Færøerne & Danmark & $\begin{array}{r}\text { Stor- } \\
\text { britannien }\end{array}$ & Total \\
\hline $\begin{array}{l}\text { Nuværende samfundsøkonomisk } \\
\text { afkast (mio. DKK) }\end{array}$ & 530 & 559 & 213 & 121 & 456 & 1.880 \\
\hline Landingsværdi (mio. DKK) & 1.236 & 2.000 & 562 & 708 & 1.447 & 5.953 \\
\hline \multicolumn{7}{|l|}{$\begin{array}{l}\text { Maksimalt samfundsøkonomisk } \\
\text { afkast (mio. DKK) }\end{array}$} \\
\hline $\begin{array}{l}\text { S1: Fiskedage konstant og } \\
\text { samlet maksimering }\end{array}$ & 533 & 559 & 237 & 285 & 749 & 2.363 \\
\hline $\begin{array}{l}\text { S2: Fiskedagsmaksimum og } \\
\text { samlet maksimering }\end{array}$ & 533 & 699 & 262 & 315 & 882 & 2.691 \\
\hline \multicolumn{7}{|l|}{ Andel af landingsværdi (\%) } \\
\hline $\begin{array}{l}\text { S1: Fiskedage konstant og } \\
\text { samlet maksimering }\end{array}$ & 43 & 28 & 42 & 40 & 52 & 40 \\
\hline $\begin{array}{l}\text { S2: Fiskedagsmaksimum og } \\
\text { samlet maksimering }\end{array}$ & 43 & 35 & 47 & 44 & 61 & 45 \\
\hline \multicolumn{7}{|l|}{$\begin{array}{l}\text { AEndring ift. nuv. samfundsøkono- } \\
\text { miske afkast (\%) }\end{array}$} \\
\hline $\begin{array}{l}\text { S1: Fiskedage konstant og } \\
\text { samlet maksimering }\end{array}$ & 1 & 0 & 11 & 136 & 64 & 26 \\
\hline $\begin{array}{l}\text { S2: Fiskedagsmaksimum og } \\
\text { samlet maksimering }\end{array}$ & 1 & 25 & 23 & 160 & 93 & 43 \\
\hline
\end{tabular}

Ved at sammenligne det nuværende niveau med scenarie 1 ses det, at der er en potentiel gevinst på 483 millioner DKK, eller $8 \%$ af landingsværdien. Sammenlignet med den mulige gevinst, fundet for forskellige typer af bundfisk og muslingefiskerier jf. Nielsen et al. 2006, er der ikke så meget at vinde ved forbedret forvaltning af det pelagiske fiskeri, som der er for bundfisk. Dette kan have to årsager; enten at det pelagiske fiskeri kan være forvaltet relativt godt i forvejen, eller fordi bestandene udviser samlende adfærd (schooling). For bestande med samlende adfærd er bestandsstørrelsen mindre vigtig for fangstomkostningerne end for bundfisk. For bundfisk er der ofte en klar negativ sammenhæng mellem fangstomkostningerne og bestandsstørrelse; når bestanden øges, mindskes fangstomkostningerne. Analysen har ikke til formål at bedømme, om det pelagiske fiskeri er forvaltet bedre end bundfiskeriet, men en årsag til, hvorfor der er sådan forskel kan være, fordi fartøjsgruppen blev reduceret under kollapset af den norske vårgydende sildebestand i perioden fra slutningen af 1970'erne til starten af 1990'erne.

Effekten af forbedret forvaltning i de forskellige lande er, at det samfundsøkonomiske afkast stiger for alle lande i begge scenarier, (ekskl. Norge, hvor det forbliver uædret). Det totale samfundsøkonomiske afkast stiger ide fem lande fra $32 \%$ af landingsværdien til $40 \%$ og $45 \%$, hhv. i scenarie 1 og 2. Dette svarer til 483-811 mio DKK, eller 8 \% af landingsværdien; størst stigning i Danmark med $23 \%$ af landingsværdien (scenarie 1) og i Storbritannien med $32 \%$ (scenarie 2).

Som beskrevet i boks 4.2 er den eneste forskel mellem scenarie 1 og 2, at det mulige antal dage, et fartøj kan være på havet, øges. Dette medfører, at antallet af fartøjer, som skal bruges til at opfylde et lands fiskedage, bliver 
reduceret. Dette forøger det samfundsøkonomiske afkast for alle landene sammenlignet med scenarie 1 , fordi det reducerer de faste omkostninger $\mathrm{pr}$ fanget enhed. Ethvert fartøj i fiskeriet har faste omkostninger som f.eks. rentebetaling af lån og forsikring, så når få fartøjer fisker i lang tid, er det mindre omkostningsfuldt, end når mange fartøjer fiskeri i kort tid.

Den internationale maksimering foretages for at identificere evt. samfundsøkonomiske gevinster ved at åbne for handel med fiskerirettigheder mellem individuelle fartøjer fra forskellige lande. Denne evt. gevinst ligger ud over den samfundsøkonomiske gevinst, der opnås med en fast fordeling af totalkvoter mellem lande, hvor individuelle kvoter alene kan handles mellem fartøjer fra samme land. Den evt. gevinst stammer således fra, at fartøjer fra de lande der er mest samfundsøkonomisk effektivitet får lov at fiske i stedet for fartøjer fra lande, der er mindre samfundsøkonomisk effektive.

Det antages, at aktørerne handler økonomisk rationelt og derved overlever kun fartøjer fra de „bedste“ lande. Dvs. den fordeling af fartøjer mellem lande, der giver det optimale samfundsøkonomiske afkast, findes ved at vælge den fordeling af fartøjer mellem lande, der samlet giver det største samfundsøkonomiske afkast. Dette sker under forudsætning af, at der ikke kan fiskes mere, end bestandene tillader, jf. produktionsfunktionerne, samt at hver national fartøjsgruppe har uændret relativ fiskeriindsats fordelt på makrel, sild (nordsøsild og norsk vårgydende sild) og industrifisk (blåhvilling, lodde og tobis). Dvs. det antages $\mathrm{fx}$, at ét industrifiskeri kan erstattes af et andet, såvel som et sildefiskeri kan erstattes af et andet, men at eksempelvis sildefiskeri ikke kan erstattes af makrelfiskeri. Identifikationen af fordelingen af fartøjer mellem lande beskrives i bilag 1, og resultatet er, at alene fartøjer af den islandske og britiske type fortsætter fiskeri, hvor norske, færøske og danske fartøjer ved kvotehandler købes ud.

Tabel 4.5. Det maksimale samfundsøkonomiske afkast (type A) med international maksimering, scenarie 1

\begin{tabular}{|c|c|c|c|c|c|c|}
\hline & Island & Norge & Færøerne & Danmark & Storbritannien & Total \\
\hline \multicolumn{7}{|l|}{$\begin{array}{l}\text { Samfundsøkonomisk afkast } \\
\text { (mio. DKK) }\end{array}$} \\
\hline Nuværende & 530 & 559 & 213 & 121 & 456 & 1.880 \\
\hline National maksimering & 533 & 559 & 237 & 285 & 749 & 2.363 \\
\hline International maksimering & 1.330 & 0 & 0 & 0 & 1.231 & 2.561 \\
\hline \multicolumn{7}{|l|}{ Andel af landingsværdi (\%) } \\
\hline Nuværende & 43 & 28 & 38 & 17 & 32 & 32 \\
\hline National maksimering & 43 & 28 & 42 & 40 & 52 & 40 \\
\hline International maksimering & 108 & 0 & 0 & 0 & 85 & 43 \\
\hline \multicolumn{7}{|l|}{ AEndringer (Mio. DKK) } \\
\hline National maksimering & 3 & 0 & 24 & 164 & 293 & 484 \\
\hline International maksimering & 797 & -559 & -237 & -285 & 482 & 198 \\
\hline \multicolumn{7}{|l|}{ ÆEndringer (\% af landingsværdi) } \\
\hline National maksimering & 0 & 0 & 4 & 23 & 20 & 8 \\
\hline International maksimering & 64 & -28 & -42 & -40 & 33 & 3 \\
\hline Total & 65 & -28 & -38 & -17 & 54 & 11 \\
\hline
\end{tabular}


Ved at lade de mest effektive fartøjer stå for fangsten giver det mulighed for et samlet yderligere forøget samfundsøkonomisk afkast på 198 millioner DKK under antagelserne fra scenarie 1 , hvor gevinsten ved national forbedring af forvaltningen udgør $8 \%$ af afkastet, giver individuel kvotehandel internationalt kun $3 \%$ ekstra. I dette scenarie skal kun fartøjerne fra Island og Storbritannien forblive i fiskeriet, mens fartøjer fra Danmark, Færøerne og Norge vil blive købt ud. Dette skyldes forskelle i fartøjsgruppernes effektivitet mellem lande. Såfremt der kun blev set på fiskeri på en bestand, ville det betyde, at kun én fartøjsgruppe, den mest effektive, ville forblive i fiskeriet. Her ser vi på flerartsfiskerier, som det fremgår af boks 4.1, og selv, hvis det totale afkast stiger, kan afkastet for enkeltbestande godt falde. Så når fangstsammensætningen varierer mellem fartøjsgrupperne, har en fartøjsgruppe måske en komparativ fordel for nogle bestande, men er mindre effektive i fangsten af andre. Det viser sig, at Island har den mest effektive fartøjsgruppe i forhold til fangst primært af industriarter, og Storbritannien har den mest effektive fartøjsgruppe, når fangsten går til konsum. Derfor vil fartøjer fra disse to lande alt andet lige finde det attraktivt at opkøbe alle kvoter, mens Norge, Færøerne og Danmark vil finde det attraktivt at sælge sine kvoter til fartøjer fra de andre lande. Det maksimale fartøjer fra et land vil være villig til at betale for yderligere kvoter, er forskellen mellem det økonomiske udbytte i den nationale og internationale maksimering. Minimumsprisen, som fartøjer fra landene, som sælger deres kvoter, er villig til at acceptere, er hvad de ville tjene under national maksimering. Derfor vil forskellen i det samfundsøkonomiske afkast mellem den nationale og internationale case på 198 millioner DKK om året blive fordelt mellem fartøjer fra lande, som køber kvoterne (Island og Storbritannien), og fartøjer fra lande som sælger kvoterne (Norge, Danmark og Færøerne). Fordelingen vil afhænge af blandt andet forhandlingsstyrke fartøjerne imellem.

Tabel 4.6. Det årlige maksimale samfundsøkonomiske afkast (type A) med international maksimering, scenarie 2

\begin{tabular}{|c|c|c|c|c|c|c|}
\hline & Island & Norge & Færøerne & Danmark & Storbritannien & Total \\
\hline \multicolumn{7}{|l|}{$\begin{array}{l}\text { Samfundsøkonomisk afkast } \\
\text { (mio. DKK) }\end{array}$} \\
\hline Nuværende & 530 & 559 & 213 & 121 & 456 & 1.880 \\
\hline National maksimering & 533 & 699 & 262 & 315 & 882 & 2.691 \\
\hline International maksimering & 1.383 & 0 & 0 & 0 & 1.467 & 2.850 \\
\hline \multicolumn{7}{|l|}{ Andel af landingsværdi (\%) } \\
\hline Nuværende & 43 & 28 & 38 & 17 & 32 & 32 \\
\hline National maksimering & 43 & 35 & 47 & 44 & 61 & 45 \\
\hline International maksimering & 112 & 0 & 0 & 0 & 101 & 48 \\
\hline \multicolumn{7}{|l|}{ ÆEndringer (Mio. DKK) } \\
\hline National maksimering & 3 & 140 & 49 & 194 & 426 & 811 \\
\hline International maksimering & 850 & -699 & -262 & -315 & 585 & 159 \\
\hline \multicolumn{7}{|l|}{ ÆEndringer (\% af landingsværdi) } \\
\hline National maksimering & 0 & 7 & 9 & 27 & 29 & 14 \\
\hline International maksimering & 69 & -35 & -47 & -44 & 40 & 3 \\
\hline Total & 69 & -28 & -38 & -17 & 70 & 16 \\
\hline
\end{tabular}


Såfremt det er muligt at fiske flere dage om året end i 2007, jf. antagelserne om det maksimalt mulige antal årlige fiskedage, vil det maksimale samfundsøkonomiske afkast i scenarie 2 ligesom i scenarie 1 blive forøget yderligere. Fartøjer fra Færøerne, Norge og Danmark vil heller ikke i scenarie 2 fortsætte fiskeri, men vil sælge deres kvoter til islandske og britiske fartøjer.

Af tabel 4.7 fremgår, hvad der sker med antallet af fartøjer, såfremt det samfundsøkonomiske afkast maksimeres. Hvor den nuværende fartøjsgruppe er på 156 fartøjer i alt, vil den efter maksimeringen falde til 97-129, og med den konsekvens, kun de effektive fartøjer fra Island og Storbritannien forbliver aktive.

Tabel 4.7. Udvikling i fartøjsgruppen ved maksimering af det samfundsøkonomiske afkast.

\begin{tabular}{lcccccc}
\hline & Island & Norge & Færøerne & Danmark & Storbritannien & Total \\
\hline $\begin{array}{l}\text { Nuværende fartøjs- } \\
\text { gruppe (antal fartøjer) }\end{array}$ & $\mathbf{3 5}$ & $\mathbf{4 5}$ & $\mathbf{8}$ & $\mathbf{3 6}$ & $\mathbf{3 2}$ & $\mathbf{1 5 6}$ \\
Reduktion nat. opt. & & & & & & \\
S1 & -3 & +1 & +2 & -25 & -18 & -42 \\
S2 & -3 & -5 & +2 & -28 & -16 & -59 \\
Fendring int. opt. & & & & & & \\
S1 & +65 & -45 & -8 & -36 & -3 & -27 \\
S2 & +59 & -45 & -8 & -36 & -19 & -48 \\
\hline
\end{tabular}

I beregningen af det maksimale samfundsøkonomiske afkast er ikke inddraget muligheden for evt. at omlægge fra industrifiskeri til konsumfiskeri og derigennem opnå højere priser. Andelen af fangsten der går til industri er antaget konstant. På trods af denne antagelse eksisterer muligheden, omfanget er dog ikke kendt.

For de traditionelt industrianvendte arter blåhvilling, lodde og tobis vurderes muligheden at være forholdsvis beskeden, da der i dag ikke i væsentligt omfang vurderes at eksistere markeder for afsætningen. Russiske fartøjer anvender dog allerede i dag blåhvilling til konsum på hjemmemarkedet. Potentialet $\mathrm{i}$ at omlægge anvendelsen af makrel fra industri til konsum vurderes også at være beskeden, idet makrel næsten udelukkende anvendes til konsum. Islandske fartøjer har med de senere års stigende fiskeri dog anvendt en vis mængde makrel til industri. Sild anvendes primært til konsum, men der er også industrianvendte landinger. Således udgjorde industriandelen af de totale sildelandinger (2007) 13 \% i Norge, 21 \% i Danmark og 65 $\%$ i Island. Forudsættes landingerne af sild i de tre lande anvendt til konsum, med den gældende gennemsnitspris i landet, svarer dette til at omsætningen i de betragtede fartøjsgrupper i de tre lande kan forøges med 296 mio. DKK, svarende til $8 \%$ af deres omsætning.

Et vist potentiale for at forøge det maksimale samfundsøkonomiske afkast af det pelagiske fiskeri i Nordøstatlanten gennem anvendelse af en større andel sild til konsum kan således være til stede. Det kan dog hverken bekræftes eller afvises, idet forudsætningen herfor er at det kan ske rentabelt. Betragtes den danske fartøjsgruppe som indgår i denne undersøgelse, 
indgår der både fartøjer, der er specialiserede i industrifiskeri (15 fartøjer) og fartøjer der fisker både sild, makrel og industrifisk (21 fartøjer). Forrentningen for de to grupper var hhv. $-4 \%$ og $6 \%$ i 2007, såvel som forrentningen i det blandede konsumfiskeri var højest i hele perioden 2001-2008 (Fødevareøkonomisk Institut 2007). Forrentningen i industrifiskeriet var således dårligere end i det blandede konsum fiskeri, hvilket kan afspejle at makrelog sildefiskeriet generelt er mere rentabelt end industrifiskeri. Der kan heraf imidlertid ikke udledes noget vedr. om det maksimale samfundsøkonomiske afkast ville blive større hvis muligheden for omlægning fra industri- til konsumanvendelse eksplicit blev inddraget i beregningen.

\subsection{Instrumenter til forøgelse af det samfundsøkonomiske afkast}

Der er en tradition for i den fiskeriøkonomiske litteratur at tage udgangspunkt i en målsætning om at maksimere det samfundsøkonomiske afkast ved udnyttelsen af fiskeressourcerne, dvs. det samfundsøkonomiske afkast, der er tilbage, når arbejdskraft og kapital har fået et normalt afkast. For at sikre det maksimale samfundsøkonomiske afkast er det afgørende, at forvaltningen tilrettelægges, så den forhindrer en overudnyttelse af fiskebestandene og samtidigt sikrer, at den nødvendige fangstkapacitet er til stede, men også forhindrer, at der er overkapacitet.

I praksis er det ikke en let opgave at regulere fiskeriet, så det maksimale samfundsøkonomiske afkast sikres, men både fra teorien og fra praksis er det kendt, at nogle forvaltningsmetoder er bedre egnede end andre til at sikre en økonomisk rationel udnyttelse af fiskebestande. Ligeledes er det kendt både fra teorien og fra praksis, at hvis der er andre målsætninger end maksimalt samfundsøkonomisk afkast, der ønsker tilgodeset, kan dette kun ske på bekostning af et mindre samfundsøkonomisk afkast. Hvis der er politiske ønsker om, at nogle bestemte grupper af fiskere (små fartøjer, fartøjer i bestemte regioner osv.) skal tildeles rettigheder i form af fiskedage, fiskekvoter osv., ud fra andre hensyn end økonomisk effektivitet, vil dette også betyde et fald i det samfundsøkonomiske afkast. Tilsvarende gælder, hvis fiskerirettigheder tildeles lande ud fra f.eks. historiske rettigheder eller gennem internationale forhandlinger og ikke ud fra aktuel økonomisk effektivitet, vil det også betyde, at det samlede samfundsøkonomiske afkast fra en given fiskebestand reduceres.

Det er vigtigt at fastslå, at det i sidste ende er et politisk valg, i hvilket omfang der skal tilstræbes et langsigtet maksimalt samfundsøkonomisk afkast, eller om den politiske prioritering sætter andre mål end økonomisk effektivitet. Det er imidlertid altid relevant at belyse de økonomiske konsekvenser af at vælge andre målsætninger end økonomisk effektivitet. Empiriske beregninger kan være med til at afdække konsekvenserne af de politiske valg. 
For at gennemføre empiriske beregninger af det samfundsøkonomiske afkasts størrelse er det nødvendigt at tage udgangspunkt i en række forenklende forudsætninger bl.a. vedrørende de biologiske og økonomiske forhold, og beregningerne vil derfor altid være usikre, dvs. beregninger af det maksimale afkast er også usikker.

Hvis udgangssituationen er, at fiskeriet ikke har været reguleret hensigtsmæssigt, er der således et potentiale for at forøge det samfundsøkonomiske afkast. Såfremt dette potentiale skal realiseres fuldt ud, kræver det således, at det langsigtede samfundsøkonomiske udbytte prioriteres eksplicit som fiskeripolitiske målsætning. Jo højere samfundsøkonomisk effektivitet prioriteres, jo mindre er mulighederne for at prioritere andre hensyn i fiskeripolitikken. F.eks. vil det en prioritering af regionalpolitiske ønsker om et bestemt bosætningsmønster og tilstedeværelse af eksempelvis kystfiskeri med mindre fartøjer i bestemte områder ske på bekostning af noget af det samfundsøkonomiske afkast. Tilsvarende vil gælde, at et ønske om at prioritere høj beskæftigelse i det primære fiskeri kun vil kunne ske ved at acceptere et mindre samfundsøkonomisk afkast.

Hvis udgangspunktet er en nedfisket bestand og overkapacitet i det primære fiskeri, dvs. for mange fartøjer og for mange fiskere, kan en målsætning om et stort samfundsøkonomisk afkast på lang sigt kun opnås, hvis der på kort sigt sker en reduktion i fangster og dermed også et midlertidigt fald i indtjening. Hvor denne balance ligger, afhænger af afvejningen mellem langsigtede gevinster og kortsigtede tab. Disse forhold er knyttet til, at det tager tid at genskabe bestande, der i udgangssituationen er mindre end de bestande, der på lang sigt giver maksimalt samfundsøkonomisk afkast. Og denne tilpasning kan kun ske ved, at fiskeriet på kort sigt reduceres. En konsekvens af dette er, at de langsigtede forbedrede fangstmuligheder for fremtidige fiskere sker på bekostning af nuværende fiskere. Nogle af disse fiskere kan være de samme, men det behøver ikke gælde for alle.

For at opnå en bedre fiskeriforvaltning på længere sigt er det vigtigt at vælge en forvaltning, der sikrer et bedre samfundsøkonomisk afkast af fiskebestandene, og afgørende er det, at de anvendte instrumenter (forvaltningsmetoder) giver de rigtige incitamenter til at forhindre for små bestande og for stor fiskerikapacitet. Det er således vigtigt at forbedre fiskeriforvaltningen på flere områder, herunder:

- at sikre, at fiskebestande forvaltes bæredygtigt i forhold til gydebiomasse og fiskeridødelighed.

- at sikre, at flådekapacitet, målt som investeret kapital, ikke er for stor i forhold til de økonomiske og biologiske rammer.

- at sikre den nødvendige løbende strukturtilpasning.

Ad a) Det er centralt for at sikre en god forvaltning af fiskerierne, at der opretholdes en gydebiomasse, der forhindrer fremtidige rekrutteringssvigt. 
Derfor må fiskeriindsatsen og dermed også fiskeridødeligheden holdes på et niveau, der minimerer risikoen for fremtidige rekrutteringssvigt.

Ad b) For at sikre et stort samfundsøkonomisk afkast er det afgørende, at fiskerikapaciteten ikke er større end nødvendigt for at udnytte fiskebestandene samfundsøkonomisk optimalt. Herved udnyttes den aktive flåde økonomisk optimalt, og det forhindres, at der er overskudskapacitet.

Ad c) For også på længere sigt at have en effektiv flåde, der kan udnytte nye teknologier både mht. effektivt fiskeri og fangstbehandling, er det af stor betydning, at forvaltningen indrettes, så fiskerne har forvaltningsmæssige rammer, der giver de rigtige incitamenter til at tage nye teknologier ind $\mathrm{i}$ fiskeriet og derved løbende sikre en strukturtilpasning af fiskeriet.

Ved at inddrage de tre forhold i valg af instrumenter i fiskeriforvaltningen vil det være muligt at opnå et stort samfundsøkonomisk afkast og dermed at sikre et samfundsøkonomisk velreguleret fiskeri.

Instrumenterne og dermed forvaltningsprincipperne kan deles op i to hovedlinjer, nemlig fysisk og økonomisk forvaltning. Fysisk forvaltning kan $\mathrm{fx}$ være adgangsbegrænsning til fiskeri gennem licenskrav, kvoteregulering i form af totale kvoter og andre former for mængdebegrænsninger eller indsatsbegrænsninger, indsatsforvaltning gennem begrænsning i antallet af fiskedage, redskabsforvaltning gennem maskestørrelser og mindstemål samt lukkede områder o. lign.

Økonomisk forvaltning kan fx være afgift på landinger og afgift på adgang til fiskeri. Markedsorienterede løsninger med brug af individuelle omsættelige kvoter har elementer af både fysisk og økonomisk karakter. Afgørende er imidlertid, at individuelt omsættelig kvoteregulering giver de samme økonomiske incitamenter til at sikre samfundsøkonomisk afkast som fangstafgifter og er derfor primært et økonomisk orienteret forvaltningssystem. Begge typer kan i teorien sikre det maksimale samfundsøkonomiske afkast. I praksis er der dog en række problemer med begge former for forvaltning. Disse kan skyldes manglende viden om fiskernes adfærd ved f.eks. afgifter eller vanskeligheder ved at sikre, at reglerne overholdes som ved f.eks. individuelt omsættelige kvotesystemer.

Økonomisk forvaltning i form af landingsafgifter har i praksis primært været anvendt som et supplement til andre former for reguleringer, jf. gennemgangen i afsnit 5.4. Landingsafgifter er, så vidt vides, ikke anvendt som det bærende fiskeripolitiske instrument nogetsteds i verden. Landingsafgifter har dog flere steder været anvendt ved siden af fysisk forvaltning. Formålet har her været omfordeling af det samfundsøkonomisk afkast fra fiskerierhvervet til samfundet, og landingsafgifter kan derfor også betragtes som et skattepolitisk instrument og således aflaste andre skattekilder og dermed reducere skatteforvridningerne i samfundet, idet en afgift på en naturressource vil være mindre forvridende end f.eks. indkomstskatter. Ud over at påvirke fiskeriet er den anden effekt således, at skatteprovenuet kan indgå i tilrettelæggelse af den generelle økonomiske politik. Hvis staten sælger kvoterne, er den skattepolitiske virkning den samme som landingsafgifter. Indi- 
viduelt omsættelige kvotereguleringer har vundet stigende indpas i fiskeriforvaltningen verden over, men normalt er kvoterne delt ud gratis og ofte efter et grandfathering princip ${ }^{3}$.

Hovedårsagen til, at fiskeriet ikke uden en eller anden form for offentlig regulering genererer et samfundsøkonomisk afkast er den manglende ejendomsret til fiskebestandene eller til fangstrettighederne, som kort sagt indebærer et „race for fish“ og dermed i den yderste form et ureguleret fiskeri.

Ud over de overnævnte reguleringsmuligheder er der derfor også muligheden at tildele ejendomsrettigheder eller fangstrettigheder til afgrænsede grupper af fiskere, hvorved forvaltningen overgår til et såkaldt comanagement system ${ }^{4}$. Dette kan f.eks. ske ved at overdrage rettighederne til en producentorganisation. Hvis en sådan organisation har en målsætning om at maksimere det samfundsøkonomiske afkast kan en sådan form for organisering af fiskeriforvaltningen vise sig mindst lige så effektiv som offentlig regulering, idet kontrol og håndhævelse kan vise sig mere effektiv og dermed billigere. På den anden side er det vigtigt at være opmærksom på, at ved en overdragelse af rettighederne afgiver samfundet muligheden for at opnå et skatteprovenu fra naturressourcen, medmindre overdragelsen faktisk sker ved salg, eller der aftales en form for betaling for at have fået overdraget rettighederne, jf. at dette sker i forbindelse med overdragelse af f.eks. olieborerettigheder. På samme måde som der ved offentlig regulering kan lægges vægt på andre målsætninger end samfundsøkonomisk afkast, kan et co-management system prioritere andre hensyn.

En gennemtænkt og administrativ veltilrettelagt fysisk forvaltning kan sikre et vist samfundsøkonomisk afkast, men det er vanskeligt at sikre den optimale sammensætning af forvaltningen, og især kan det være vanskeligt at sikre strukturtilpasning og dermed teknologisk dynamik i fiskerierhvervet, når den primære regulering er fysiske begrænsninger. Dertil kommer, at denne form for regulering er ressourcekrævende mht. detailregulering, kontrol og håndhævelse.

I de gennemførte beregninger over alternative scenarie i afsnit 4.2. er det implicit antaget, at flåden kan reguleres, så de beregnede samfundsøkonomiske afkast kan sikres. Som det fremgår ovenfor, er dette muligt med både landingsafgifter og omsættelige kvoter, og i princippet også hvis de enkelte fartøjer tildeles de korrekte individuelle ikke omsættelige kvoter, mens fiskedage og andre former for fysiske restriktioner ikke vil sikre de beregnede samfundsøkonomiske afkast, medmindre der gennemføres en urealistisk stram fysisk kontrol. Tilsvarende kan brug af et co-management system generere samfundsøkonomisk afkast til organisationen, der har fået tildelt rettighederne.

I de analyserede fartøjsgrupper er der individuelt omsættelige kvoter i Island, Danmark og Færøerne. Island og Færøerne (sild og makrel) har haft denne forvaltning i en længere årrække, og der vurderes ikke at være mulighed for at forbedre forvaltningen væsentligt. I Danmark er individuelt omsættelige kvoter af nyere dato, og der vurderes at være mulighed for at for- 
øge det samfundsøkonomiske afkast, jf. afsnit 4.2. Det maksimale samfundsøkonomiske afkast vurderes imidlertid at kunne opnås uden væsentlige ændringer i forvaltningen, men derimod ved at lade systemet virke over en længere periode.

Det norske og britiske pelagiske fiskeri er reguleret ved individuelt ikkeomsættelige kvoter, for Storbritannien dog administreret via producentorganisationerne, som jf. teorien ikke fungerer ligeså godt og fleksibelt som individuelt omsættelige kvoter. Men da kvoterne handles sammen med fartøjet, kapitaliseres kvoteværdien i fartøjet, som derved vurderes at stige væsentligt i værdi. Konsekvensen er, at systemerne i praksis virker næsten som individuelt omsættelige kvotesystemer. Det i afsnit 4.2 identificerede samfundsøkonomiske afkast afspejler da også, at forvaltningen fungerer relativt effektivt. Samtidig har forvaltningen i begge fartøjsgrupper eksisteret i en lang årrække. Der vurderes dog stadig at være gevinster ved at adskille kvoterne fra fartøjerne i forvaltningssammenhæng og herigennem introducere egentlige individuelt omsættelige kvotesystemer.

Hvis vi ser på beregningerne for de forskellige scenarier, er der nogle interessante observationer, hvis vi som udgangspunkt antager, at fiskerierne er reguleret med enten landingsafgifter eller ved salg af individuelle omsættelige kvoter. Beregningerne er gennemført under den restriktive antagelse, at de enkelte landes fartøjer er ens. I beregningerne er nemlig brugt gennemsnitstal, hvilket betyder, at det samfundsøkonomiske afkast under mere realistiske antagelser om, at fartøjerne har forskellig effektivitet inden for hvert land, vil være større end det beregnede. Den anden interessante observation er, at den faste fordeling af totalkoter mellem lande betyder fastfrysning af en struktur. Dvs. beregningerne viser, at det samfundsøkonomiske afkast reduceres, når der pålægges restriktioner.

Hvis vi ser på det mest vidtgående scenarie med handel med kvoter mellem lande, svarer dette til resultaterne fra international handelsteori om, at der er effektivitetsgevinster ved international arbejdsdeling. I beregningerne er resultatet, at kun to landes fartøjer vil fiske på de pelagiske arter, der er med i beregningerne. Det vil samtidigt give det største samfundsøkonomiske afkast, der så efterfølgende kan fordeles mellem alle lande, f.eks. ved brug af en fordelingsnøgle der svarer til de initiale kvoter mellem landene.

I praksis vil resultater ikke blive, som angivet i scenariet, da forudsætningen om, at alle fartøjer inden for hvert land er et gennemsnitsfartøj, ikke gælder. Derimod vil der ske en specialisering, således at de mest effektive fartøjer fra alle lande vil deltage i fiskeriet.

Det er relevant at stille spørgsmålet, hvordan en sådan total optimering af det samfundsøkonomiske afkast kan organiseres. Hvis alle involverede lande overdrager forvaltningen til en fælles organisation, der derefter fastsætter de årlige kvoter, står for opkrævning af fangstafgifter eller for salg af kvoter, og at denne organisation har som målsætning at maksimere det langsigtede samfundsøkonomiske afkast, vil dette betyde, at de mest effektive fartøjer fra alle involverede lande vil forblive som aktive fiskefartøjer. Herved vil 
der ske en international arbejdsdeling inden for fiskeriet på samme måde som inden for alle andre områder, hvor der er frihandel.

Denne organisering kan imidlertid samtidigt sikre, at de enkelte lande opnår et samfundsøkonomisk afkast, idet provenuet fra landingsafgifter eller fra salg af kvoter skal fordeles mellem de lande, der initialt overdrog fiskerirettighederne til den fælles organisation. Fordelingen af provenuet kan f.eks. være baseret på fordelingen af kvoterne mellem landene forud for etableringen af den fælles organisation.

Trods scenariernes forenklede karakter viser beregningerne tydeligt, at der er tab af samfundsøkonomisk afkast ved at pålægge restriktioner om bestemte flådestrukturer i forbindelse med tilpasninger, og at der er tydelige gevinster i form af øget samfundsøkonomisk afkast, hvis der sker en international arbejdsdeling, hvor de mest effektive fartøjer fra de enkelte lande har mulighed for at fiske. Den løbende strukturtilpasning kan sikres ved såvel fangstafgifter som ved omsættelige kvoter. Hvis det samfundsøkonomisk afkast skal tilfalde samfundet, er fangstafgifter en direkte vej til at sikre dette, men det samme kan opnås ved salg af fiskerettigheder. Hvis det samfundsøkonomiske afkast skal fordeles mellem lande og/eller bruges til at kompensere dem, der ikke længere vil komme til at deltage i fiskeriet, er det nødvendigt at bruge fangstafgifter eller at sælge de individuelle fangstkvoter. 



\section{Fordelingen af det samfundsøkonomiske afkast}

Fiskerilovgivningerne i flere af de nordiske lande angiver, at samfundet som helhed ejer fiskebestandene. De angiver imidlertid ikke noget om, hvem i samfundet, der ejer fiskebestandene og derfor heller ikke noget om, hvem der har krav på det samfundsøkonomiske afkast. Deltagere i fiskeriaktiviteter, ejere af og ansatte på fiskefartøjer, kan have et legitimt krav på at få en andel. Ejere såfremt der er større risiko i at investere i fiskefartøjer end i andre erhverv. Arbejdskraften i det omfang der er større ulemper forbundet med at arbejde som fisker end i andre erhverv. Såfremt det ikke sikres, at der investeres den nødvendige kapital i fiskeriet samt rekrutteres den nødvendige og bedst mulige arbejdskraft, kan det samfundsøkonomiske afkast ikke opretholdes. Kapital og arbejdskraft skal således som minimum opnå den andel af det samfundsøkonomiske afkast, der sikrer fiskeri på et niveau, hvor det samlede samfundsøkonomiske afkast ikke falder.

Samtidig har det resterende samfund, repræsenteret ved den offentlige sektor, som ejer af fiskebestandene også et legitimt krav på en andel af det samfundsøkonomiske afkast, her opgjort som afkast uden fradrag af tilskud mv. (type A). Denne andel opnås gennem skattesystemet $\mathrm{i}$ form af indkomstskat, selskabsskat, i visse lande en mindre ressourceskat og i nogle få lande betaling for fiskeriforvaltning, kontrol og ejerskab af fiskerirettigheder. Disse offentlige indtægter imødegås dog af offentlige udgifter til fiskeriet i form af tilskud og fiskeriforvaltningsomkostninger.

Fiskeriet kan sammenlignes med andre erhverv, hvor produktionen er baseret på naturressourcer. Således er der i en række lande skat på olieudvinding. I Norge opkræves f.eks. $50 \%$ af overskuddet af olieproduktionen oveni den generelle selskabsskat på $28 \%$. Også på vandkraft i Norge eksisterer en ekstra høj kommunal afgift. I Danmark er der forhandlet en aftale på plads om skat på olie og naturgas. Ressourceskat i nordiske fiskerier er imidlertid næsten ukendt, og hvor de anvendes, er beskatningen meget lav. I Norge anvendes således en afgift på 0,2 \% af landingsværdien, såvel som der i Island i 2002 blev indført en afgift på 9,5 \% af afkastet.

Der vurderes at være et potentiale for, at den offentlige sektor som ejer af fiskeressourcerne kan opnå en større andel af det samfundsøkonomiske afkast. Muligheden begrænses i de tilfælde, hvor samfundet tilbage i tiden har tildelt et begrænset antal fiskere eksklusive rettigheder til fiskeri, og når disse fiskere har videresolgt de tildelte rettigheder til en ny generation. Den nye generation har ved betaling for fiskerirettigheder allerede betalt det samfundsøkonomiske afkast én gang til de tidligere ejere, idet værdien af fiskerirettighederne kapitaliseres. Og denne betaling kan ikke eller meget vanske- 
ligt beskattes med tilbagevirkende kraft. Der eksisterer således et usynligt samfundsøkonomisk afkast ved, at førstegenerationsrettighedshaverne fik rettighederne tildelt gratis. Derved har de fået foræret det samfundsøkonomiske afkast, uden at der er mulighed for at opkræve det senere via skatter. Potentialet for den offentlige sektor ligger derfor primært i, at der indføres beskatning, når det samfundsøkonomiske afkast forventes at stige i fremtiden f.eks. som en konsekvens af bedre forvaltningsmæssige rammer, større bestand eller bedre markedsforhold.

\subsection{Fordeling af det samfundsøkonomiske afkast} 2000-2008

\section{Beregningsmetode}

Det samfundsøkonomiske afkasts fordeling mellem kapital, arbejdskraft og den offentlige sektor kan beregnes særskilt for de tre grupper som:

Arbejdskraft:

+totale udgifter til arbejdskraft i fiskeriet

-indkomstskat

-arbejdskraftens lønindtægter i alternativ anvendelse

+indkomstskat af lønindtægter i alternativ anvendelse

Arbejdskraftens andel af det samfundsøkonomiske afkast

Kapital:

+overskud før finansielle udgifter og skat

-selskabsskat

-finansielle indtægter i alternativ anvendelse

+selskabsskat af finansielle indtægter i alternativ anvendelse

Kapitals andel af det samfundsøkonomiske afkast

Den offentlige sektor:

+indkomstskatteprovenu

+selskabsskatteprovenu

+ressourceskatteprovenu

+indtægter fra brugerbetaling i fiskeriet

-tilskud til fiskeriet

-fiskeriforvaltningsomkostninger

Den offentlige sektors andel af det samfundsøkonomiske afkast.

Kapitalens og arbejdskraftens andel af det samfundsøkonomiske afkast beregnes uden hensyntagen til, om den tilfalder nuværende eller tidligere fiskere. Evt. salg af fiskerirettigheder fra tidligere fiskere til nuværende er ikke inddraget i beregningen. Dette gælder både for salg af fiskerirettigheder 
særskilt og tilknyttet fiskerfartøjer. Der skelnes således indledningsvist ikke mellem om kapitalens og arbejdskraftens andel af det samfundsøkonomiske afkast tilfalder nuværende eller tidligere fiskere.

I beregningen af arbejdskraftens andel af det samfundsøkonomiske afkast kendes de totale udgifter til arbejdskraft i fiskeriet og i alternativ anvendelse fra kapitel 4.

Sammenholdes disse med antallet af fuldtidsbeskæftigede i kapitel 4, kendes lønnen for officerer og mandskab i hhv. fiskeriet og i alternativ anvendelse. Indkomstskatten er beregnet på grundlag af disse gennemsnitslønninger gange indkomstskatteprocenten. Indkomstskatteprocenten i fiskeriet identificeres svarende til det gennemsnitlige lønniveau, idet der herigennem tages højde for bundfradrag, fiskerfradrag og skattesystemets progression. Fiskerfradraget antages fuldt udnyttet. Indkomstskatteprocenten i alternativ anvendelse beregnes tilsvarende, bortset fra at lønniveauet er lavere, og fiskerfradraget ikke er gældende.

I beregningen af kapitalens andel af det samfundsøkonomiske afkast er overskud før finansielle udgifter og skat beregnet efter fradrag af afskrivninger, såvel som selskabsskatten er beregnet som selskabsskatteprocenten gange overskud efter finansielle udgifter. Finansielle indtægter i alternativ anvendelse beregnes som $6 \%$ af den investerede kapital, jf. kapitel 4, og selskabsskat $\mathrm{i}$ alternativ anvendelse beregnes som selskabsskatteprocenten gange finansielle indtægter.

I beregningen af den offentlige sektors andel af det samfundsøkonomiske afkast anvendes indkomst- og selskabsskatteprovenuet bestemt i beregningen af hhv. arbejdskraftens og kapitalens andel af det samfundsøkonomiske afkast. Ressourceskatteprovenuet er i den betragtede periode alene relevant $\mathrm{i}$ Norge, hvor den udgør 0,2 \% af landingsværdien. Tilskud til fiskeriet, fiskeriforvaltningsomkostninger og indtægter fra brugerbetaling i fiskeriet kendes fra kapitel 4.

Den beregnede fordeling af det samfundsøkonomiske afkast baseres således på flere beregningsforudsætninger. Dette indebærer, at resultaterne er behæftet med betydelig usikkerhed og derfor skal fortolkes med forsigtighed.

\section{Data}

Regnskabsdata, lønstatistik, data for tilskud til fiskeriet, omkostninger til fiskeriforvaltning og indtægter fra brugerbetaling i fiskeriet er beregnet som angivet i kapitel 4. Aflønningen af officerer og mandskab i fiskeriet og alternative erhverv for alle landene er angivet i tabel 5.1, samt selskabs- og indkomstskatteprocenterne. 
Tabel 5.1. Beregnede årlige bruttoindkomster af arbejdskraft i faktisk og alternativanvendelse, indkomstskatteprocenter for disse indkomster og selskabsskat, 2007.

\begin{tabular}{|c|c|c|c|c|c|}
\hline & Island & Norge & Færøerne & Danmark & Storbritannien \\
\hline \multicolumn{6}{|l|}{ Aflønning i fiskeri $(1.000 \mathrm{DKK})^{1}$} \\
\hline Officerer & 898.000 & 1.004 .900 & 1.244 .000 & 804.800 & 1.365 .900 \\
\hline Besætning & 514.500 & 722.000 & 711.000 & 563.400 & 956.200 \\
\hline \multicolumn{6}{|l|}{ Indkomstskat } \\
\hline Officerer & 30 & 31 & 48 & 49 & 34 \\
\hline Besætning & 25 & 28 & 43 & 43 & 32 \\
\hline \multicolumn{6}{|l|}{ Alternativ aflønning (1.000 DKK $)^{2}$} \\
\hline Officerer & 484.800 & 415.200 & 364.800 & 429.100 & 359.200 \\
\hline Besætning & 322.500 & 298.300 & 255.400 & 300.400 & 251.500 \\
\hline \multicolumn{6}{|l|}{ Indkomstskat } \\
\hline Officerer & 29 & 38 & 43 & 42 & 19 \\
\hline Besætning & 26 & 37 & 37 & 39 & 17 \\
\hline Selskabsskat (pct. af overskud) ${ }^{3}$ & 18 & 28 & 18 & 25 & 25 \\
\hline \multicolumn{6}{|c|}{$\begin{array}{l}\text { Note: } \\
{ }^{1)} \text { Faktisk aflønning er beregnet ud fra de kendte årlige udgifter til løn, delt med beskæftigelsen, under antagelse af at } \\
\text { forskellen mellem officer og besætning er den samme i faktisk som i alternativ aflønning. For Færøerne og Island antages } \\
\text { dog, at Iøn til officerer er } 75 \% \text { højere end til besætning. } \\
{ }^{2)} \text { Alternative aflønninger antages at svare til årsindkomsten for en procesoperatør i industrien og for en funktionær. } \\
{ }^{3)} \text { Der er for fiskerindkomst taget højde for fiskerfradrag i de lande, hvor et sådant eksisterer. } \\
\text { Kilder: Lønstatistik (Statistics Iceland (c), Norges Statistik, Danmarks Statistik og United Kingdom Statistics) og Information } \\
\text { om indkomst- og selskabsbeskatning (Icelandic Internal Revenue Directorate, Skatteministeriet i Norge og Danmark, og } \\
\text { Færøernes Hjemmestyre (a) og EUROSTAT 2009). }\end{array}$} \\
\hline
\end{tabular}

De angivne indkomstskatteprocenter er beregnet under hensyntagen til bundfradrag, fiskerfradrag, skattesystemets progression og arbejdsgiverudgifter. Indkomstskatteprocenterne er beregnet for lønniveauet for officerer og mandskab i hhv. fiskeriet og for arbejdskraft i alternativ anvendelse.

Af tabellen fremgår det, at selskabsskatten med $18 \%$ er lavest i Island og på Færøerne, for Danmark og Storbritannien er den med 25 \% højere, mens den i Norge er højest med 28 \%. Indkomstskatteprocenten er højest i Danmark og på Færøerne, både i fiskeriet og i alternativ anvendelse. Den laveste indkomstskatteprocent i fiskeriet er i Island, mens det i alternativ anvendelse er Storbritannien, som ligger lavest. For Island er indkomstskatten i fiskeriet og i andre erhverv stort set ens, hvilket kan skyldes lav progressivitet i skattesystemet samt, at der ikke eksisterer noget fiskerfradrag. I Norge er indkomstskatteprocenten lavere i fiskeriet end i andre erhverv trods højere aflønning i fiskeriet, hvilket skyldes tilstedeværelsen af store fiskerifradrag.

Aflønningen i fiskeriet er beregnet ud fra fiskeriets lønomkostninger samt antal ansatte. Tabel 5.1 angiver den faktiske årsindkomst samt den alternative årsindkomst begge fordelt på officerer og besætning. Det fremgår, at der i Danmark og Island er den mindste forskel mellem den faktiske årsindkomst og alternativindkomsten. I Danmark er lønnen 188 \% større i fiskeriet end i alternative erhverv for både besætning og officerer, mens lønnen i Island for officerer og besætning er hhv. $185 \%$ og 160 \% større end alternativaflønningen. Lønnen før skat er i Norge og på Færøerne mellem 2 til 3 gange så høj i fiskeriet som i alternative erhverv. Dette skyldes, at Norge og Færøerne har både højere lønninger i fiskeriet samt lavere alternativaflønninger sammenlignet med Island og Danmark. For Storbritannien findes 
både de højeste aflønninger i fiskeriet samt de laveste alternativaflønninger, og lønnen her er næsten 4 gange så høj i fiskeriet som i alternative erhverv, hvilket gælder for både officerer og besætning. Det er dog rimeligt at forvente en vis højere aflønning i fiskerierhvervet sammenlignet med alternative erhverv, da fiskeriet indebærer flere og større ulemper. Andre erhverv indeholder ulempetillæg, hvilket der også bør tages højde for vedr. arbejdskraften i fiskeriet, da der er lange og skæve arbejdstider samt større risiko for arbejdsskader. For kapitalen i fiskeriet er et højere afkast også til en vis grad rimeligt, da investeringsrisikoen kan være er højere i fiskeriet end i mange andre erhverv.

\section{Fordelingen af det samfundsøkonomiske afkast i 2007}

Det samfundsøkonomiske afkasts fordeling i 2007 er angivet for de fem udvalgte fiskerier i tabel 5.2. Det samfundsøkonomiske afkast er angivet efter fradrag af offentlige nettoudgifter til fiskeriet (type B).

Tabel 5.2. Fordeling af det samfundsøkonomiske afkast (type B), 2007, mio. DKK og pct ${ }^{1}$.

\begin{tabular}{|c|c|c|c|c|c|}
\hline & Island & Norge & Færøerne & Danmark & $\begin{array}{l}\text { Storbri- } \\
\text { tannien }\end{array}$ \\
\hline Nettoaflønning af kapital & 332 & 177 & 82 & 44 & 177 \\
\hline Nettoaflønning af arbejdskraft & 102 & 248 & 61 & 27 & 157 \\
\hline Skatteindtægter & 129 & 135 & 71 & 50 & 122 \\
\hline Offentlige udgifter til fiskeri & -23 & -113 & -32 & -60 & -85 \\
\hline Total & 507 & 446 & 181 & 60 & 371 \\
\hline \multicolumn{6}{|l|}{$\%$ - fordeling af samf. øk afkast } \\
\hline Kapital & 63 & 40 & 45 & 74 & 48 \\
\hline Arbejdskraft & 20 & 55 & 33 & 44 & 42 \\
\hline Den offentlige sektor & 17 & $\underline{5}$ & 21 & $\underline{-18}$ & 10 \\
\hline Total & 100 & 100 & 100 & $\overline{100}$ & 100 \\
\hline
\end{tabular}

Den offentlige sektors andel af det samfundsøkonomiske afkast opnås gennem skattesystemet i form af indkomstskat, selskabsskat, fratrukket de offentlige udgifter til fiskeriet i form af tilskud og fiskeriforvaltningsomkostninger.

Den offentlige sektors andel er i 2007 positiv i alle de udvalgte lande på nær Danmark. Andelen er størst i Færøerne (21 \%), mens den er lidt lavere for Island, Storbritannien og Norge (hhv. $17 \%, 10 \%$ og $5 \%$ ). Den offentlige sektors andel er imidlertid negativ i Danmark, hvor andelen af det samfundsøkonomiske afkast er på -18 \%, hvilket er forårsaget af bl.a. store tilskud samt en dyr forvaltning af fiskeriet.

I Danmark er fiskerisektorens bidrag til den offentlige sektor således mindre, end den er i andre sektorer, dvs. det offentlige har relativt flere udgifter end indtægter fra fiskeriet set i sammenligning med andre sektorer.

Kapitalens andel af det samfundsøkonomiske afkast er størst i Danmark og Island med hhv. 74 \% og $63 \%$, mens andelen ligger nogenlunde på niveau i 
Færøerne, Norge og Storbritannien. For alle de udvalgte fiskerier gælder det, at kapitalaflønningen er væsentligt større i fiskeriet end i alternative erhverv.

Arbejdskraftens andel af det samfundsøkonomiske afkast er med $55 \%$ størst i Norge, men er også højere end i andre erhverv for de resterende lande. Danmark og Storbritannien ligger forholdsvist jævnt med hhv. $44 \%$ og $42 \%$, mens arbejdskraftsandelen for Færøerne og Island er på hhv. 33 \% og $20 \%$.

Det samfundsøkonomiske afkasts fordeling mellem nuværende aktive og tidligere ejere af fiskerirettigheder, som evt. har fået fiskerirettigheder foræret og har solgt dem, er ikke inddraget i beregningerne. Kapitalens andel inkluderer således både aktive og tidligere ejere af fiskerirettigheder tilbage til dem, der som de første fik tildelt eksklusive fiskerirettigheder gratis. Såfremt det samfundsøkonomiske afkast har været konstant over tid, og de aktive fiskere har betalt „fuld“ pris til de tidligere fiskere, er hele kapitalens andel af det samfundsøkonomiske afkast givet til de tidligere ejere af fiskerirettigheder.

Når der købes fiskerirettigheder, øger det omkostningerne til fiskeriet. Dog er det kapitalen og ikke arbejdskraften, som primært betaler den ekstra omkostning, da arbejdskraften normalt aflønnes ved en fast andel af landingsværdien eller overskuddet (jf. boks 5.1). Hvis andelen af landingsværdien til arbejdskraften ikke påvirkes af ændrede forvaltningsformer, vil det primært være kapitalejerne, som får en ekstra omkostning ved køb af fiskerirettigheder, mens arbejdskraftens aflønning stiger, da et optimalt reguleret fiskeri bør medføre større landingsværdier for det tilbageværende mandskab.

Fordelingen af det samfundsøkonomiske afkast mellem tidligere og nuværende ejere af fiskerirettigheder afhænger også af, hvor lang tid forvaltningssystemet med fiskerirettigheder har været gældende. Hvis det har eksisteret i lang tid som i Island, har størstedelen af førstegenerationsrettighedshaverne videresolgt deres rettigheder og indkasseret rettighedernes værdi i form af betaling for salg af deres fiskerirettigheder. Når forvaltningen har været gældende i mange år, er forventningen, at det samfundsøkonomiske afkast er stabiliseret, så de nuværende rettighedshavere ikke får en væsentlig gevinst ved salg af deres rettigheder. I Danmark, hvor rettighedssystemet kun har været gældende i få år, forventes rettighedshaverne at tjene ved salg, da man kan forvente at det samfundsøkonomiske afkast stiger over tid. Årsagen er den bedre forvaltning som indebærer, at værdien af rettighederne er steget (Eriksen and Flaaten 2006).

\section{Boks 5.1. Aflønningsformer.}

I de udvalgte lande er systemet for aflønning af arbejdskraft forholdsvis ens. Der er i hvert land lavet en rammeaftale mellem fartøjsejerne og fiskernes fagforening, hvor der er fastsat minimumsløn til besætningen gældende for fiskeriet i hele landet. Besætningen får en fast andel af landingsværdien eller bruttoindtjeningen, men er sikret en minimumsløn. Lønnen ligger i de betragtede pelagiske fartøjsgrupper i alle landene væsentligt over minimumslønnen. Beregningsmodellen for lønandelene er forskellige fra rederi til rederi, men lønandelen varierer i alle landene mellem besætningsmedlemmerne, alt efter hvilke arbejdsopgaver de har. Skipperens andel er størst. 
Betragtes Norge som eksempel, opnår mandskabet en fast andel af fangstværdien (bruttoindtjeningen). Hvert besætningsmedlems gennemsnitlige individuelle andel af bruttoindtjeningen udgør 1,99 \%. Bruttoindtjeningen beregnes på følgende måde:

Landingsværdi

- Specificerede udgifter (til telefon og breve relateret til fiskeriet, til salt, is og andre konserveringsmidler, til køleapparater, til emballage, til rengøring af sengetøj, til aflastning af fangsten, til brændstof, til skatter på fangsten, til betaling af forhandleren, til betaling af havneplads til fartøjet, til betaling af forsikring af andet end fartøjet, samt til løn til kokken og medhjælpere)

$=$ Bruttoindtjening

Bruttoindtjeningen er, hvad besætningen på fartøjerne skal deles om. I den færøske fartøjsgruppe får besætningen som udgangspunkt altid en grundandel på 17,5 \%, samt procenttillæg, alt efter hvilken position det enkelte besætningsmedlem har på fartøjet. Bruttoindtjeningen kan både beregnes pr. tur og på årsbasis. Ved beregning pr. tur får mandskabet løn præcist efter indtjeningen på den konkrete tur. Bruges denne aflønningsform, kan det imidlertid være svært at tiltrække mandskab til mindre rentable fangstture, da alle vil have tilskyndelse til at deltage på de mest økonomisk givtige fangstture, typisk i makrelsæsonen. Aflønningen i dele af det danske pelagiske fiskeri beregnes på årsbasis.

Udvikling i fordelingen af det samfundsøkonomiske afkast 2000-2008

Fiskerilovgivningerne i de udvalgte lande angiver, som nævnt tidligere, ikke, hvem der har krav på det samfundsøkonomiske afkast, og hvordan det skal fordeles. Både kapital og arbejdskraft skal sikres en aflønning, der muliggør opretholdelsen af en optimal udnyttelse af fiskeriressourcerne. Det resterende samfund har samtidig også et legitimt krav på en del af det samfundsøkonomiske afkast. Udviklingen i den faktiske fordeling af det samfundsøkonomiske afkast type B mellem kapital, arbejdskraft og den offentlige sektor er for fire af de udvalgte lande angivet i figur 5.1. For Storbritannien er beregningerne alene foretaget for 2007, og udviklingen i det samfundsøkonomiske afkast kan derfor ikke vises.

Den offentlige sektors andel består af skatteprovenu fra selskabs- og indkomstbeskatning samt af indtægter fra brugerbetaling, hvilket fratrækkes omkostninger til fiskerfradrag, tilskud og fiskeriforvaltning. Kapitalens og arbejdskraftens andel er angivet efter fradrag af henholdsvis selskabsskat og indkomstskat.

Udvikling i det offentliges andel af det samfundsøkonomiske afkast er forskellig i de fire lande, hvilket skyldes landenes forskellige forvaltningsmetoder. I Island er det offentliges andel svagt positivt for næsten hele perioden på nær for år 2001, 2004 og 2008, hvor den stort set er nul. Det offentliges andel i Norge er meget svingende. I år 2000 og 2003 er det offentliges andel af det samfundsøkonomiske afkast negativt med omkring 100 mio. kr. For de resterende år ligger det offentliges andel nogenlunde stabilt omkring nul. Som det ses på figur 5.1, er det offentliges andel på Færøerne negativ i år 2000 samt 2004, mens 2003 og 2005 kun havde en svagt positiv andel sammenlignet med de resterende år. Færøerne er dog det land, hvor det offentlige har den største andel af det 
samfundsøkonomiske afkast sammenlignet med de andre udvalgte lande. Derimod er Danmark det land, hvor det offentliges andel af fiskeriet er mest negativ. Kun i år 2005 og 2006 er afkastet svagt positiv, mens det i år 2001, 2003 og 2004 er yderst negativ med mellem 50 og 100 mio. kr. underskud.
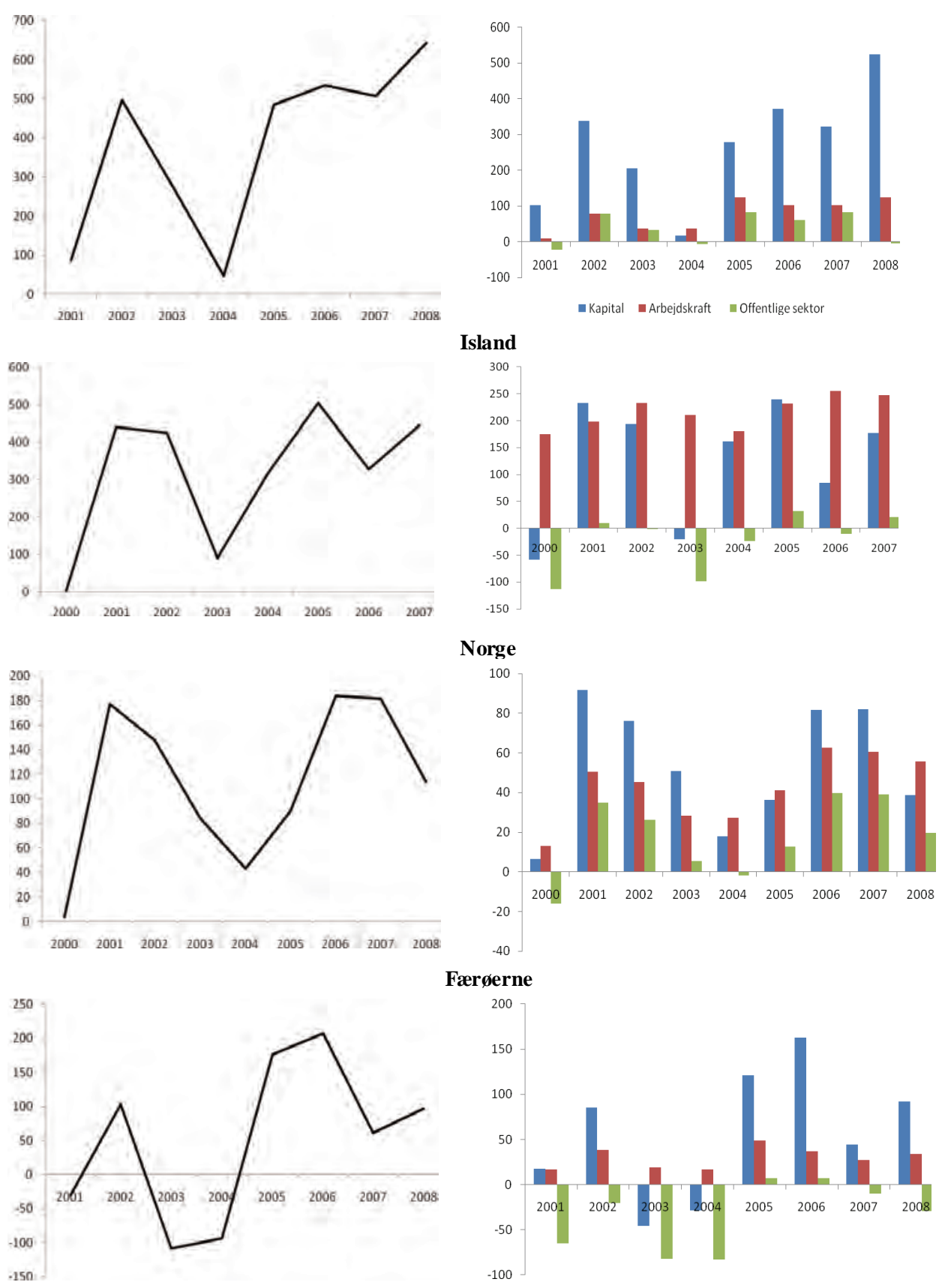

Færøerne

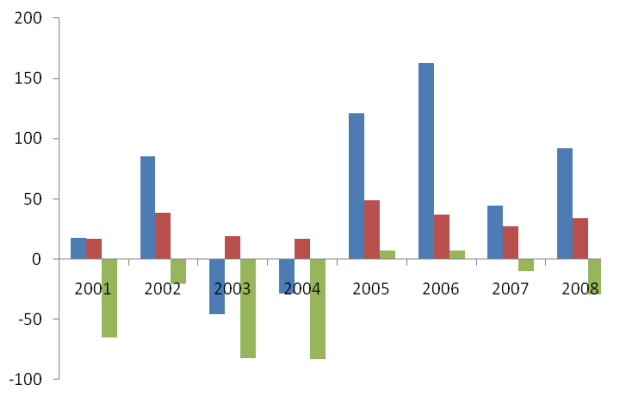

Danmark

Figur 5.1 Udviklingen i det samfundsøkonomiske afkast, totalt og fordelt, mio. DKK. 
Størrelsen på kapitalens andel af det samfundsøkonomiske afkast er for alle de medvirkende lande meget svingende. For Island er andelen meget positiv i næsten hele perioden på nær 2004, hvor andelen er omkring nul. Norges kapitalandel af det samfundsøkonomiske afkast er også meget positiv for de fleste år; dog er afkastet negativt i år 2000 og 2003. Kapitalandelen på Færøerne er meget positiv i hele perioden på nær år 2000 samt 2004, hvor kapitalafkastet er markant mindre end i de andre år. For Danmark bidrager kapitalafkastet negativt til det samfundsøkonomiske afkast i år 2003 og 2004. Der eksisterer dog i den resterende del af perioden et stort positivt, men svingende kapitalafkast i det danske pelagiske fiskeri.

Arbejdskraftens aflønning udgør i alle landene og for alle årene en positiv andel af det samlede samfundsøkonomiske afkast. Samtidig er den gennem hele perioden forholdsvist stabil for alle landene.

Fordelingen af det samfundsøkonomiske afkast udvikler sig ikke ens for de fire lande, bortset fra at 2003 og 2004 for alle landene var år med lavt samfundsøkonomisk afkast. Årsagen til det store fald i det samfundsøkonomiske afkast var et fald i fiskepriserne på verdensmarkedet samt, for nogle lande, mindre landingsmængder, jf. kapital 4. Dette fald i fangstværdien reducerede kapitalandelen og den offentlige sektors andel, hvor arbejdskraftaflønningen var mere stabil. Kapitalandelen er direkte påvirket af udsving i fangstværdien, da det skaber afkastet af investeringerne. Derudover er kapitalandelen også påvirket af fiskeriomkostningerne som f.eks. stigning i oliepriser eller øgede vedligeholdelsesomkostninger. Den offentlige sektor er bl.a. afhængig af skatteindtægter fra fartøjsejerne og er derfor også sårbare over for ændringer i fangstværdien.

Påvirkningen af arbejdskraftsandelen afhænger af aflønningsformen, jf. boks 5.1. Nogle aflønninger er en procentdel af fangstværdien, mens andre er mere uafhængig af markedsudsving gennem de indgående overenskomster. Med en uafhængig aflønningsform påvirkes arbejdskraftsandelen i mindre grad ved et fald i priserne eller stigende fiskeriomkostninger, hvilket er årsagen til en mere stabil udvikling for arbejdskraftsandelen.

Forskellen i landenes forvaltningsmetoder afspejles bl.a. i, hvor stor andel af det samfundsøkonomiske afkast den offentlige sektor har. Forvaltningsmetoderne både optimerer og omfordeler det samfundsøkonomiske afkast og bidrager derigennem med et større afkast til den offentlige sektor. Når der i den pågældende periode reguleres fra myndighedernes side ved at indføre fiskerirettigheder, er det de nye investorer, som bærer byrden, mens de gamle ejere eller den offentlige sektor får gevinsten, alt efter om rettighederne gives væk på baggrund af grandfathering, eller om myndighederne sælger rettighederne. At arbejdskraftens andel kun påvirkes lidt af forvaltningen skyldes måden, hvorpå lønnen fastlægges. At der er aftalt en fast procentdel af fangstværdien eller bruttoindtjeningen gør at arbejdskraftsandelen ikke er direkte påvirket af ændret fiskeriforvaltning, eksempelvis introduktion af individuelt omsættelige kvoter som i Danmark i 2003. 
Ændret forvaltning af fiskerierne kan både mindske og øge kapitalens andel af det samfundsøkonomiske afkast. Forbedret forvaltning vil mindske fiskeriomkostningerne, mens køb af fiskerirettigheder hæver omkostningerne ved fiskeriet. Forvaltning vil øge den offentlige sektors andel og arbejdskraftsandelen, når den giver en bedre forvaltning af fiskeressourcerne, større landingsværdier og mindre omkostninger for de tilbageværende fartøjer og fiskere.

\subsection{Fordelingsmæssige konsekvenser af bedre fiskeri- forvaltning}

Størrelsen af det samfundsøkonomiske afkast er vigtigt for samfundet. Afkastet repræsenterer den indkomst, som kan være med til at forbedre den samlede samfundsøkonomi, herunder at opbygge kapitalapparatet. Det samfundsøkonomiske afkast kan i teorien blive beskattet uden dødvægtstab og dermed være med til at reducere forvridningerne ved andre former for beskatning som f.eks. beskatning af arbejdsindkomst. Staten kan således ved øget ressourcebeskatning erstatte nogle af de sædvanlige skatter og derved reducere dødvægtstabet. Det er vigtigt for samfundet, at der skabes et samfundsøkonomisk afkast. I forhold til økonomisk effektivitet spiller fordelingen en mindre vigtig rolle.

Fællesejede fiskeressourcer er ofte sårbare over for overfiskning. Ved overfiskeri mistes meget af det samfundsøkonomiske afkast, som følge af overkapacitetsomkostningerne og høje fiskeriomkostninger, der grundlæggende skyldes for små fiskebestande. Der findes mange måder at bekæmpe overkapacitet på. Tekniske restriktioner, såsom udstyr eller tidsmæssige restriktioner for fiskeriet kan bidrage til at reducere fangsterne til et samfundsmæssigt optimalt niveau. Disse restriktioner vil imidlertid ikke føre til en økonomisk effektivisering af fiskeriet. En stor del af det samfundsøkonomiske afkast vil stadig gå tabt, fordi disse restriktioner enten vil betyde ineffektive fiskere eller perioder med ikke udnyttet fangstkapacitet. De forvaltningsmetoder, som har vist sig mest effektivt til at generere et samfundsøkonomisk afkast, er baseret på tildeling af fiskerirettigheder, herunder individuelle kvotesystemer. I et kvotesystem vil hver producent blive tildelt en andel af den samlede fangst. Producenterne har nu incitament til at maksimere overskuddet, givet den tilladte fangstmængde. Som følge heraf reduceres omkostningerne, mens fangstværdien stiger. Hvis kvoterne også er omsættelige, øges effektiviteten yderligere, da de mest effektive fiskere vil købe kvoter fra mindre effektive, og derved vil det samlede overskud øges og forbedre det det samfundsøkonomiske afkast. En omlægning af forvaltningssystemet fra teknisk forvaltning af kvoter eller fra ikke omsættelige til omsættelige kvoter kan resultere i betydelige stigninger i det samfundsøkonomiske afkast. Danmark er et godt eksempel herpå. Forvaltningssystemet blev omlagt til omsættelige kvoter i 2003. I resultaterne i denne rapport kan man klart se en skillelinje mellem perioden før og efter 2003. Før var afka- 
stet negativt men den har været bestandig positiv siden 2005. Denne tendens forventes at fortsætte og det samfundsøkonomiske afkast forventes yderligere forøget, idet omlægning og tilpasning tager lang tid (Andersen, Andersen og Frost 2010).

Erfaringer fra lande, som bruger fuldt omsættelige kvoter, viser, at der kan opnås et højere samfundsøkonomisk afkast (Arnason 2005). Derimod har det vist sig vanskeligt for den offentlige sektor at få del i dette samfundsøkonomiske afkast ved f.eks. at pålægge skatter på fiskeressourcen (Hannesson 2005). De få undtagelser, som findes er i fiskerier, hvor der hovedsageligt fiskes af udenlandske fartøjer som i Namibia (Wiium og Uulenga 2003). Det har tidligere været påstået, at det er vigtigere for et samfund, at der dannes et samfundsøkonomisk afkast, end hvordan det fordeles. Alligevel er det vigtigt at diskutere, hvordan afkastet fordeles ved omlægning af forvaltningen til individuelt omsættelige kvoter. Dette afhænger af, hvordan kvoterne uddeles. Såfremt kvoterne sælges til højestbydende på auktion, går størstedelen af gevinsten til den offentlige sektor. Marginale gevinster går til ejerne af fiskerirettigheder som følge af effektivisering. Såfremt kvoterne derimod uddeles på grundlag af historiske fangster, går hovedparten til ejerne af fiskerirettigheder, mens den offentlige sektor alene får en andel af effektiviseringen gennem de generelle skatter. På længere sigt tjener den offentlige sektor gennem forbedret konkurrenceevne, bedre udnyttelse af produktionsfaktorer og frigivet kapital som følge af højere produktivitet og afkast, som kan anvendes bedre i andre erhverv. Effekten på arbeidskraft kan være mere kompliceret. På kort sigt kan effektivisering medføre reduceret behov for arbeidskraft i fiskeriet. På længere sigt vil større lønsomhed føre til højere lønandele i fiskeriet, såvel som den økonomiske vækst, der følger med den frigivne kapital, generelt kan føre til bedre vilkår for arbejdstagere.

Fordelingen af det samfundsøkonomiske afkast begrænses ikke kun til fordeling mellem ejere af fiskerirettigheder og staten. Arbejdskraften får også en betydelig andel af det samfundsøkonomiske afkast. Størrelsen på arbejdskraftens andel afhænger i høj grad af de aflønningsformer, som anvendes. Faste lønninger giver arbejdskraften mindst andel i det samfundsøkonomiske afkast. Derimod er der meget større mulighed for arbejdskraften for at få del i det samfundsøkonomiske afkast, hvis arbejdskraftens aflønning er fastlagt som en andel af fangstværdien.

Kvoteregulering medfører incitament for den enkelte kvoteejer til at maksimere sit overskud pr. kvoteenhed. Dette fører blandt andet til en reduktion i fangstomkostningerne og højere fangstværdier over tid. Visse generelle problemer kan dog opstå ved aflønning som andel af fangstværdi. Kvoteejerne har incitament til at opgive lavest mulige fangstværdi og højest mulig fangstomkostninger. Det kan de opnå for eksempel ved vertikal integration af fangst og landing, hvor prisen, som bruges, til en vis grad er fiktiv, og omkostninger kan flyttes mellem led i virksomheden. Problemet kan 
reduceres ved brug af egne regler om priser som anvendes, når fisk bliver solgt udenom markeder (Matthiasson og Valsson 2000).

\subsection{Instrumenter til omfordeling af det samfundsøko- nomiske afkast}

Dette afsnit fokuserer på, hvilke instrumenter som kan anvendes for at omfordele det samfundsøkonomiske afkast fra kapital og arbejdskraft til den offentlige sektor. Det vurderes ikke om omfordelingen rent faktisk er ønskelig. Der fokuseres på instrumenter, som synes at være relevante for fiskerisektoren.

Fiskeri kan være et godt aflønnet erhverv, som genererer et betydeligt samfundsøkonomisk afkast. På grund af, at fiskerier som regel er fælleseje, vil det samfundsøkonomiske afkast tiltrække nye fiskere, indtil afkastet ikke længere eksisterer, medmindre staten foretager forvaltningsmæssige indgreb. Dette er det velkendte „tragedy of the commons“. Staten kan enten gribe ind ved fysiske eller økonomiske tiltag. Fysiske tiltag inkluderer regler, om hvor og hvornår det er lovligt at fiske, om fiskemetode, type fartøj eller tilladt fangstmængde. Den sidste metode, dvs. at regulere mængde gennem fangstkvoter, er blevet meget udbredt de seneste år. Staten kan også bruge økonomiske tiltag for at få del i det samfundsøkonomiske afkast, for eksempel ved at beskatte afkastet. Det skal i princippet give samme resultat, om man regulerer med kvoter eller skatter, men skatter har ikke været anvendt af politiske årsager. Uregulerede fiskerier er som regel ikke særligt rentable for fiskerne, og indføres der en ressourceskat som led i en omlægning af fiskeriet fra et ureguleret fiskeri til et reguleret, vil dette føre til konkurser på kort sigt hos en række fiskere. Derimod er det velkendt, at det samfundsøkonomiske afkast kapitaliseres i prisen på den begrænsende produktionsfaktor, som er fiskerkvoten i tilfælde med kvoteregulering. Jo mere omsættelighed, der indføres, jo større grad af kapitalisering vil der ske. I et system med omsættelige kvoter, der uddeles gratis, vil kvotehandel føre til, at førstegenerations indehavere af kvoterne får tildelt størstedelen af det samfundsøkonomiske afkast som opstår som følge af den bedre forvaltning af fiskeriet. Den offentlige sektor får kun en andel af afkastet gennem det generelle skattesystem. En omfordeling fra fiskerne til den offentlige sektor forudsætter derfor tilstedeværelsen af både fysisk og økonomisk forvaltning. Økonomiske forvaltningsinstrumenter gennemgås derfor i nedenstående afsnit som et omfordelingsinstrument som supplerer den fysiske fiskeriforvaltning.

Mange problemer kan opstå ved at introducere ressourceskatter ind i et fysisk reguleret system. For eksempel i et kvotereguleret system er fiskere, som køber kvoterne, villige til at købe, når kvoteprisen er lig værdien af det forventede fremtidige afkast, risikoen taget i betragtning. Driften hos fiskere, som må købe alle sine kvoter, bliver derfor ikke mere lønsom end normalt, det vil sige at der intet afkast bliver dannet udover, hvad der kan opnås 
i andre erhverv. Dette fører til problemer i forhold til senere omfordeling mellem stat og fiskere. For eksempel risikerer en senere indføring af ressourceskatter at ramme en sådan fisker og gøre hans fiskeri urentabelt. Det er derfor lettere at introducere omfordelingen af det samfundsøkonomiske afkast samtidig med forbedret fiskeriforvaltning, idet det øgede afkast kan beskattes uden negativt at påvirke præmisserne for det eksisterende fartøjs fiskeri. I praksis kan dette også vise sig at være vanskelig på grund af den store usikkerhed, som er knyttet til omfanget af det samfundsøkonomiske afkast. Det er til og med vanskeligt at bevise, om det er en ændring i forvaltningen, som har ført til en ændring i det samfundsøkonomiske afkast, da afkastet kan variere betydeligt fra år til år med biologiske faktorer, vejr, priser og så videre. Dette gælder specielt for pelagiske fiskerier, hvor bestandsstørrelsen kan variere kraftigt fra år til år. Samtidig er der i næsten alle fiskerier tildelt eksklusive rettigheder til at fiske, hvor det allerede er for sent at introducere økonomisk forvaltning med tilknyttet beskatning af det samfundsøkonomiske afkast samtidig med tildeling af rettigheder.

Der eksisterer forskellige instrumenter, som kan anvendes til omfordeling af det samfundsøkonomiske afkast. Mange forskellige typer afgifter findes i forhold til beskatning af andre naturressourcer, som genererer et samfundsøkonomisk afkast, for eksempel olie, mineraler og vandkraft. Det er mest normalt at knytte afgifterne til den producerede mængde, indtægt eller overskuddet direkte. Ingen af disse forslag er uden problemer. Den første, afgift på produceret mængde, vil medføre uens afgiftsniveauer. Afkastet er afhængigt af mange faktorer. Et fast afgiftsniveau vil udgøre forskellig andel af afkast i forskellige fiskerier. Det kan have uheldige konsekvenser for forvaltningen af fiskerierne, for eksempel at marginalt rentable fiskerier bliver stoppet, og at afkastet de generede forsvinder. Alligevel er denne type afgift kendt fra olievirksomheder verden over (NOU 2000).

Afgifter på omsætningen er et typisk eksempel på økonomiske forvaltningsinstrumenter. De har også nogen af de samme ulemper som afgifter på den producerede mængde. For at en afgift knyttet til omsætning skal være effektiv, skal den være tilpasset hvert fiskeri for sig. Ellers vil den føre til ujævne afgiftsniveauer i forskellige fiskerier og måske ødelægge rentabiliteten i de marginalt rentable fiskerier.

Det tredje forslag er direkte afgifter på det samfundsøkonomiske afkast, som foreslået af Garnaut og Ross (1975). Afkastskatter er brugt meget i forbindelse med beskatning af afkastet i olievirksomheder (NOU 2000) og vandkraft (LOV 1999). Fordelene ved direkte beskatning af afkastet er, at det i princippet kan tage hensyn til forskelligt afkast i forskellige fiskerier. Den vil derfor ikke føre til, at fiskerier som i udgangspunktet er rentable bliver gjort urentable på grund af afgiften. Afgifter på afkastet kræver detaljerede data på indtægt og omkostninger, som kan være vanskelig at efterprøve og dyrt at holde opsyn med. En forenklet udgave af afkastafgift er allerede anvendt i islandske fiskerier. I 2002 blev der indført fiskeafgift på 9,5 \% af det estimerede afkast. Selv om en 9,5\% afgift af afkastet virker betydelig, viser estimater 
baseret på lejeprisen af kvoter, at kun en brøkdel af det samfundsøkonomiske afkast bliver opfanget af afgiften, faktisk kun mellem 3-5\% (Matthiasson og Valsson 2000, Kristofersson 2010). Alle disse afgifter har det til fælles, at i systemer, hvor det samfundsøkonomiske afkast har kapitaliseret sig i for eksempel kvotepriser, vil de føre til negativ rentabilitet $\mathrm{i}$ industrien.

Andre typer afgiftsformer eksisterer. I de tilfælde, hvor kvoter ikke allerede har været tildelt, kan man auktionere dem bort. I de fleste tilfælde har rettigheder allerede været uddelt, og hvis det er sket uden begrænsninger i periodelængde, vil da auktioner være vanskelige at indføre. Hvis kvotetildelingerne derimod har en periodebegrænsning, kan fornyelse af kvoteuddeling ske ved bortsalg eller auktioner. Endvidere kan afgifter pålægges som opkrævning af forvaltningsomkostninger og der kan ske en inddragelse af samfundsøkonomisk afkast ved at fjerne tilskud og fiskerfradrag. Fordelen ved den type tiltag er, at de ikke nødvendigvis opfattes som en skat, siden det handler om betaling for ydelser. Samtidig kan den offentlige sektors nettoudgifter reduceres væsentligt. Y derligere afgiftsformer inkluderer afgifter på omsætning af fiskerettigheder eller fartøj. Dette kan delvist retfærdiggøres ved at ændringer på ejerskab medfører reelle omkostninger for det offentlige. Afgifter som er udover det, vil derimod føre til øgede transaktionsomkostninger, reducere gevinsten ved omsætning, hæmme reduktionen af fangstomkostninger og reducere produktiviteten.

Endelig kan man indføre ejendomsskatter, eller tilsvarende, på fiskerirettigheder. Argumentet for dette kan være, at ejendomsrettighedernes værdi stiger pga. at den almindelige samfundsudvikling, og altså stiger mere, end køberne og sælger forventede, da kvoterne blev handlet. Det kan være meget forskelligt, hvad den skattemæssige værdi af fiskerirettighederne er i forskellige fiskerier, som igen kan føre til ujævn og uretfærdig fordeling af afgiften. Dette kan løses ved, at staten tager en hvis andel af de frigivne kvoter hvert år, som en slags nedskrivning af kvoterne. Kvoter, som staten får ved denne metode, kan så sælges, for eksempel på auktioner. Et sådan system har allerede været testet i Chile, hvor $10 \%$ af totalkvoten sælges om året til højstbydende på auktion (Arnason 2005).

Tidsbegrænsede brugerrettigheder kan, som kort nævnt tidligere, også fungere som en slags skat på det samfundsøkonomiske afkast. Hvis staten uddeler rettighederne i en begrænset periode, kan rettighederne sælges, når perioden er ovre. For eksempel giver det danske system fiskerne rettigheder med et opsigelsesvarsel på 8 år, mens den færøske forvaltning skal revideres i 2018. Hvis denne tidsbegrænsning bliver taget seriøst, vil det føre til, at kun afkastet i den begrænsede periode kapitaliseres i kvoteprisen. Resten af afkastet, for fremtidige perioder efter tidsbegrænsningen, kan i princippet tilhøre staten. Det bør dog nævnes, at sådanne systemer medfører lejerproblemer, hvor statens langsigtede interesser i form af at maksimere det samfundsøkonomiske afkast, ikke er de samme, som fiskernes interesser, som vil være at maksimere overskuddet over lejeperioden. Denne forskel i interesser kan føre til øgede problemer med blandt andet snyd med rettighederne 
og ulovligt fiskeri, når lejeperioden nærmer sig afslutningen med tab af afkast til følge. Ligeledes bør det nævnes, at begrænsninger på kvoteperioden kan have negative virkninger på den langsigtede investeringsplanlægning $\mathrm{i}$ fiskeriet og dermed på fiskernes effektivitet. Dette vil, alt andet lige, betyde en reduktion i det samfundsøkonomiske afkast, men kan være prisen for på længere sigt at indføre en hensigtsmæssig ressourcebeskatning.

Resultaterne i denne rapport viser klart, at fiskerne (mandskabet) får en betydelig andel af det samfundsøkonomiske afkast. Dette hænger til en vis grad sammen med, at det mest normale aflønningssystem er at betale en andel af fangstværdien og/eller af overskuddet (McConnell og Price 2006). Ændringer i fiskeriforvaltning, som fører til en stigning i det samfundsøkonomiske afkast vil derfor mest sandsynligt have positive effekter på fiskernes løn på lang sigt (Casey et al 1995, Brandt og Ding 2008). Selv om en effektivisering på kort sigt kan reducere antallet af fiskere, vil øget rentabilitet føre til højere løn for hver tilbageværende aktive fisker. Empiriske samt teoretiske resultater tyder på, at overgangen til kvotesystemer har ført til højere løn for fiskere (Brandt og Ding 2008). Det er i den sammenhæng interessant, at fiskerne ofte har været imod indførslen af kvotesystemer (Eythorsson 2000, Guyader og Thebaud 2001), hvor årsagen til denne modvilje kan være begrundet i synliggørrelsen af afkastet i kvoteprisen. Den andel af afkastet, som betales i form af løn, er mindre synlig og bliver formodentligt ofte underestimeret. Aktiv modstand fra fiskerne kan således delvist forklares med opfattelsen af retfærdighed i fordeling af afkaststigningen. Der kan dog også være andre årsager til fiskernes modstand, for eksempel at kvotelejen bliver taget med som omkostning i lønopgørelsen. Derved kan ejere af fiskerirettigheder øge deres afkastsandel betydeligt og tage noget af afkastet, som ellers ville være tilfaldet mandskabet. Dette kan ske ved at leje mest mulig kvote i stedet for at købe kvote (Eythorsson 2000, Brandt og Ding 2008 og Pinckerton og Edwards 2009).

Island er et godt eksempel på problematikken knyttet til fordelingen af det samfundsøkonomiske afkast fra fiskerier. Kvotesystemet blev oprindeligt indført i de pelagiske fiskerier i 1978 og i de demarsale fiskerier i 1984. Med tiden er de fleste arter på Island blevet kvotereguleret. Kvoterne har vært frit omsættelige helt fra starten og defineret som langsigtede rettigheder fra 1990. Kvotepriserne har i perioder vært meget høj, hvilket tyder på, at fiskerierne skaber et højt samfundsøkonomisk afkast. Systemet har endvidere kapitaliseret det samfundsøkonomiske afkast. Selv om kvoteejerne har rettighederne til at fiske, ejes fiskebestandene af det islandske folk ifølge den islandske forfatning. Der har været politisk uenighed om fordelingen af det samfundsøkonomiske afkast siden indførelsen af systemet. Under det nuværende system har størstedelen af afkastet været delt mellem arbejdskraft og ejere af fiskerirettigheder. Der har dog kun været fokuseret på kvoteejernes andel af det samfundsøkonomiske afkast i den islandske debat, da den er meget synlig. I 2002 blev der indført fiskeafgift på 9,5 \% af det estimerede afkast, som nævnt tidligere. Det var et forsøg på at imødekomme 
kritikken rettet mod fordelingen af afkastet mellem staten og kvoteejerne. Fiskeafgiften skulle indføres gradvist og stige til 9,5 \% i 2009. På grund af dårlige bestandstilstande hos torsk, skete implementeringen imidlertid langsommere end planlagt. Meget tyder på, at metoden som bruges for at estimere afkastet, undervurderer den, og at fiskeafgiften derfor kun udgør 3-5\% afgift på afkastet (Matthiasson og Valsson 2000, Kristofersson 2010).

Ved regeringsskiftet 2009 kom to modstandspartier af kvotesystemet i flertal på det islandske storting og har lovet at ændre systemet. Det er ikke afgjort nøjagtigt, hvilke ændringer som skal gennemføres, men en central ide er at indføre en fast årlig reduktion i de permanente kvoter med op til 5 \% om året, ligesom i det chilenske system. Nye vurderinger af effekten af en sådan systemændring viser, at den vil have meget alvorlige konsekvenser for rentabiliteten på fiskeribedrifterne på Island (Kristófersson 2010). Grunden til dette er først og fremmest alderen på det islandske kvotesystem. Det estimeres, at mellem 76 og $83 \%$ af kvoterne på torsk, kuller og sej er blevet omsat på et eller andet tidspunkt siden 1991. Kun en lille del det samfunds$ø$ øonomiske afkast er derfor tilbage hos de nuværende fiskere. Størstedelen er blevet omfordelt gennem salg af kvoter. Som forventet kan man også se, at rentabiliteten i fiskerindustrien ikke er bedre end alternative erhverv. Det er estimeret, at hvis kvoterne reduceres med $2 \%$ om året, er dette overskud borte, givet et afkastningskrav på 10 \% (Kristofersson 2010).

En central pointe fra de islandske erfaringer er således, alt andet lige, at det er nemmere at omfordele fra erhvervet til den offentlige sektor i forbindelse med, at forvaltningen forbedres, frem for når forvaltningen har været gældende i en længere årrække. Årsagen er, at 2. generationsrettighedshavere allerede har betalt gevinsten til 1. generation, da de købte deres fiskerirettigheder. Pointen er illustreret i tabel 5.3.

Muligheden for at omfordele det samfundsøkonomiske afkast til den offentlige sektor fra dem, som oprindeligt har fået afkastet foræret (1. generations rettighedshavere), afhænger af udskiftningen i erhvervet, samt af den fremtidige udvikling i det samfundsøkonomiske afkast. Jo større udskiftning, des mindre kan det samfundsøkonomiske afkast opkræves i erhvervet.

Tabel 5.3. Mulighed for at omfordele samfundsøkonomisk afkast til den offentlige sektor fra dem der har modtaget det.

\begin{tabular}{|c|c|c|c|}
\hline \multirow{2}{*}{$\begin{array}{l}\text { Fremtidig udvikling } \mathrm{i} \\
\text { samfundsøkonomisk afkast }\end{array}$} & \multicolumn{3}{|c|}{ Udskiftning af ejere af fiskerirettigheder } \\
\hline & Fuld & Delvis & Ingen \\
\hline Stigende & $\begin{array}{l}\text { Stigende afkast kan } \\
\text { opkræves fra alle } \\
\text { ejere af fiskerirettig- } \\
\text { heder }\end{array}$ & $\begin{array}{l}\text { Stigende afkast kan opkræves fra } \\
\text { alle ejere af fiskerirettigheder } \\
\text { Hele afkastet kan opkræves fra } \\
\text { aktive 1. generationsejere af } \\
\text { fiskerirettigheder }\end{array}$ & God \\
\hline Uændret & Ingen & $\begin{array}{l}\text { Afkast kan opkræves fra aktive } 1 . \\
\text { generationsejere } \\
\text { af fiskerirettigheder }\end{array}$ & God \\
\hline
\end{tabular}


Endvidere kan fremtidige ikke forventede stigninger i det samfundsøkonomiske afkast opkræves uden større vanskeligheder, hvor uændret afkast alene kan opkræves hos 1 . generationsrettighedshaverne. Stigninger i det samfundsøkonomiske afkast kan forventes, hvor der introduceres ny regulering, og muligheden for at opkræve afkastet er således bedst, hvis det sker samtidigt med introduktionen af ny regulering.

Stigninger i det samfundsøkonomiske afkast kan dog også forårsages af eksterne faktorer, som $\mathrm{fx}$ permanente stigninger i rekrutteringen af fisk eller permanent stigende fiskepriser. Ved en sådan stigning i afkastet kan omfordeling indføres samtidigt, således at alene stigningen i det samfundsøkonomiske afkast omfordeles. Det er dog afgørende, at stigningen er permanent, da omfordelingen ellers vil føre til et fald i effektiviteten.

Hvis det ikke er af betydning, om det samfundsøkonomiske afkast alene opkræves fra dem, der har modtaget det (1. generationsrettighedshavere) eller af alle, er risikoen, at nye ejere af fiskerirettigheder kommer til at betale for kvoterne to gange. Dels købesummen til tidligere ejere, dels opkrævningen fra den offentlige sektor. Konsekvensen heraf kan være, at nye ejere af fiskerirettigheder må udtræde af erhvervet som følge af for store omkostninger, og som følge heraf at fiskeriindsatsen bliver mindre, end hvad der er samfundsmæssigt optimalt. En sådan situation kan give den offentlige sektor en større andel af afkastet, men vil samtidig indebære, at fiskebestandene udnyttes mindre effektivt samfundsmæssigt. Omfordeling vil i en sådan situation gå ud over den samfundsmæssige effektivitet af fiskeriet.

Danmark introducerede individuelt omsættelige kvoter i sildefiskeriet i 2003, efterfulgt af makrel og industrifisk i 2007. Samtidig blev i det demarsale fiskeri introduceret ny regulering i 2007 (Fødevareministeriet 2005). I forbindelse med denne forvaltningsændring blev det besluttet at muligheden for gradvist at indføre ressourcegebyr skulle undersøges, og konsekvensen blev, at der er introduceret en Fiskefond (for det demarsale fiskeri og industrifiskeriet), hvor en vis variabel andel af de totale kvoter hvert år tilbageholdes og omfordeles til fiskere efter politiske ønsker. Tilsvarende ordning er gældende for silde- og makrelfiskeriet, hvor der også tilbageholdes kvoteandele, dog fast specificeret til $6 \%$ og $4 \%$ for hhv. sild og makrel. Således har fonden understøttet et generationsskifte via omfordeling af kvoter til yngre fiskere. Fonden kunne også sælge kvoterne og herigennem opkræve en del af det samfundsøkonomiske afkast. Dette er imidlertid ikke sket til dato.

Der er i Danmark således ikke i forbindelse med den nye regulering først på sild i 2003 og derefter på makrel, industrifisk og demarsale arter i 2007, indført ressourcegebyr. Der er ingen omfordeling af samfundsøkonomisk afkast til den offentlige sektor. Muligheden vurderes dog stadig at være til stede, men den vil gradvist blive mindre, jo længere tid der går. Dog skal evt. introduktion af et ressourcegebyr ses i sammenhæng med at forvaltningen er indført med et opsigelsesvarsel på 8 år.

Omvendt medførte ny regulering af det demersale fiskeri samt industrifiskeriet i 2005 et væsentligt fald i antallet af fartøjer i løbet af kort tid i efter- 
året 2006. Efterfølgende er antallet af fartøjer faldet yderligere. Dette foregik ved, at nogle fiskere købte fartøjskvoteandele fra andre, uden at der som tidligere blev givet væsentlig ophørsstøtte hertil. Da mange af de fartøjer, der udgik af fiskeriet, havde gæld til den danske Fiskeribank (som var statsejet), kunne fartøjerne med indtægterne fra salg af fartøjskvoteandele betale deres gæld til Fiskeribanken. Dette indebar, at Fiskeribanken fra at have et betydeligt underskud endte med at opnå et overskud, inden den efterfølgende blev lukket og nedlagt. Indirekte fik den offentlige sektor således en del af det samfundsøkonomiske afkast som et engangsbeløb.

I de øvrige nordiske lande er erfaringerne med opkrævning af det samfundsøkonomiske afkast beskedne, ud over relativt små afgifter i Norge. I Grønland eksisterer en afgift på landing af rejer siden 1980'erne (Grønlands Hjemmestyre 2005). Størrelsen af afgiften stiger progressivt med prisen på rejer, og minimumsstørrelsen har siden starten af 1990'erne været fastsat på et niveau, at indtægterne fra afgiften ikke har oversteget $1 \%$ af landingsværdien.

I lande uden for Norden er der erfaringer med omfordeling af det samfundsøkonomiske afkast til den offentlige sektor i New Zealand, Namibia, Chile, Rusland og Estland. New Zealand introducerede afkastafgift i en kortere periode, men stoppede i forbindelse med en aftale med fiskeriindustrien (Hannesson 2005). Chile, Estland og Rusland har alle solgt fiskerirettigheder på auktion. I Chile er metoden begrænset til få fiskerier. Estland har auktioneret kvoter, og i Rusland har kvoter til fiskeriet i Stillehavet også vært solgt på auktion (Hannesson 2005, Anferova, Vetemaa og Hannesson 2004). Erfaringerne er imidlertid ikke entydigt positive i landene, som har anvendt metoden, og Rusland anvender den ikke mere. Problemerne har bl.a. været, at det begrænsede antal firmaer i Chile har samarbejdet om at holde priserne lave, og at de russiske fiskere har købt små kvoter, samtidig med at manglende kontrol har ført til overfiskeri (Grønlands Hjemmestyre 2005). Namibia har lagt en afgift på fiskekvoter, som skal omfordele noget af det samfundsøkonomiske afkast fra fiskerier, som hovedsageligt drives af udenlandske fartøjer (Wiium og Uulenga 2003). 


\section{Referencer}

Andersen, P., J. L. Andersen and H. Frost 2010. ITQs in Denmark and Resource Rent Gains, Marine Resource Economics, 25:11-22.

Anferova, E., M. Vetemaa og R. Hannesson 2004. Fish quota actions in the Russian far east: a failed experiment, paper presented at the Conference at the International Institute of Fisheries Economics and Trade in Tokyo.

Arnason, R., 2005. Property rights in fisheries: Iceland's experience with ITQs. Reviews in Fish Biology and Fisheries, 15(3): 243-264.

Bjørndal, T. Gordon, D.V. and Bezabih, M. 2010. The Potential for Rent in the North Sea Herring Fishery. Working Paper, 2010-14. Department of Economics, University of Calgary.

Brandt S. and Ding N., 2008. Impact of property rights on labor contracts in commercial fisheries, Ocean \& Coastal Management, 51(11): 740-748.

Casey K., Dewees C., Turris B. and Wilen J., 1995. The effects of individual vessel quotas in the British Columbia halibut fishery. Marine Resource Economics, 10:211-30.

Clark, C. W. 1990. Mathematical Bioeconomics - the optimal management of renewable resources, second edition, John Wiley \& Sons, Inc.

Copes, P. 1972. Factor Rents, Sole Ownership and the Optimum Level of Fisheries Exploitation, The Manchester School of Social and Economic Studies, 40, 145-63.

Danmarks Statistik. Lønstatistik. Tilgængelig på http://www.dst.dk.

Eriksen, G.H and Flaaten, O. (2006). The Norwegian coastel fishery with 8-14,9 meter vessels, I: Nielsen, M. [red.] Focus on the economy of the Nordic fisheries, FOI report nr 186. p. 45-66.

Eskja. 2010. Company Account. Personal communication with Benedikt Jóhannsson.

European Commission, DirectorateGeneral for Maritime Affairs and Fisheries 2010. http://ec.europa.eu/dgs/ maritimeaffairs_fisheries/, accessed July 2010.

Eurostat. 2009. Taxation trends in the European Union - Data for the EU
Member States and Norway. Available: http://epp.eurostat.ec.europa.eu/.

Eythorsson E. 2000. A decade of ITQmanagement in Icelandic fisheries: consolidation without consensus. Marine Policy. 24(6):483-92.

Fiskeri- og Kystdepartementet I Norge (2007). Strukturpolitikk for fiskeflåten. St. melding. Nr 21. (2006-2007). Retrieved 26 May 2010, from: http://www.regjeringen.no/pages/19562 02/PDFS/STM200620070021000DDDP DFS.pdf.

Fiskeridirektoratet i Danmark.. Danske landinger af fisk. Tilgængelig på http://fd.fvm.dk/.

Fiskeridirektoratet i Norge. a. Lønnsomhetsundersøkelse for fiskeflåten - helårsdrevnefiskefartøy i størrelsen 8 meter største længde over, tilgængelig på http://www.fiskeridir.no/.

Fiskeridirektoratet i Norge. b. Fiskefartøy og fiskarar, konsesjonar og årlege deltakaradgangar, tilgængelig på http://www.fiskeridir.no/.

Food and Agricultural Organisation of United Nations 2007. The State of World Fisheries and Aquaculture 2006.

Frost, H. 2004. Naturressourcer som fisk og olie i et frit marked. Det går ikke, Samfundsøkonomen, 2, 30-37.

Fødevareministeriet i Danmark2005. Aftale om Ny Regulering af dansk fiskeri, Regeringen og Dansk Folkeparti, 3. november 2005.

Fødevareøkonomisk Institut. Fiskeriregnskabsstatistik, serie F, København.

Fødevareøkonomisk Institut, København 2001-2008, Fiskeriets økonomi tilgængelig på http://www.foi.life.ku.dk/.

Færøernes Hjemmestyre. a. Information om skattesystemet.

Færøernes Hjemmestyre. a. Information om tilskud til fiskerflåden og omkostninger til fiskeriforvaltning.

Færøernes statistiske kontor, Færøske landinger af fisk. Tilgængelig på http://www.hagstova.fo/portal/page/pora 1/HAGSTOVAN/Hagstova_Foroya.

Garcia, S. M. and C. Newton 1997. Current situation, trends and prospects in world capture fisheries, in PiKitch, Huppert and Sissenwine (edt), Global trends: Fisheries management, American 
Fisheries Society Symposium 20, Maryland, USA.

Garnaut, R. and Ross, A.C. 1975, Uncertainty, risk aversion and the taxing of natural resource projects, Economic Journal, 85(2): 272-87.

Gordon, H. Scott 1954. The economic theory of a common property resource: the fishery. Journal of Political Economy 62: 124-142.

Grønlands Hjemmestyre 2005. Omsættelige kvoter og andre metoder til regulering af rejefiskeriet, rapport fra det uvildige udvalg, nedsat af Grønlands Hjemmestyre, november.

Guyader O. and Thebaud O., 2001. Distributional issues in the operation of rights-based fisheries management systems. Marine Policy, 25(2): 103-112.

Hannesson, R., 2005. Rights based fishing: Use rights versus property rights to fish. Reviews in Fish Biology and Fisheries, 15(3): 231-241.

Hønneland, G. 2005. Fisheries Management in the Russian Federation. Ebbin, S. (eds): A Sea Change: The Exclusive Economic Zone and Governance Institutions for Living Marine Resources, 49-63. (2005). Springer, Printed in the Netherlands.

Icelandic Internal Revenue Directorate. Information on taxation. Available at http://www.rsk.is/.

International Council for Exploration of the Sea (ICES). 2008. Report from the Advisory Committee of Fisheries Management, available at http://www.ices.dk/indexfla.asp

Islands Havbiologiske Forskningscenter, tilgængelig på http://www.hafro.is/.

Kristófersson, D.M., 2010. Greinargerð um áhrif fyrningarleiðar á afkomu og rekstur útgerðarfyrirtækja. Institide of Economic Studies.

Lindebo, E., A. Hoff and N. Vestergaard 2002. Economic and physical measures of capacity: A comparative analysis of Danish trawlers, paper presented at the $\mathrm{XI}^{\text {th }}$ biannual Conference in the International Institute of Fisheries Economics and Trade, Wellington, New Zealand, August 2002.

LOV-1999-03-26-14. Lov om skatt av formue og inntekt. (www.lovdata.no). Matthiasson, T., and B. Valsson. 2000. Ex-vessel Price of Cod in Iceland. Empirical and Contract-Theoretical Consideration. Microbehavior and Macroresults: Proceedings of the Tenth Biennial
Conference of the International Institute of Fisheries Economics and Trade, R.S. Johnston and A.L. Shriver, eds. Corvallis, OR: IIFET.

McConnell K.E. and Price M., 2006. The lay system in commercial fisheries: Origin and implications. Journal of Environmental Economics and Management, 51(3): 295-307.

North East Atlantic Fisheries Commission (2009). NEAFC Fisheries Status Report 1998-2007. London, June 2009.

Nielsen, M., Cozzari, B., Eriksen, G., Flaaten, O., Gudmundsson, E., Løkkegaard, J., Petersen, K. og Staffan Waldo, 2006. Økonomien i de nordiske fiskerier. Fokus på resourcerenten. Tema Nord. 2006:540

Nilssen, F., 2010. The Norwegian Institute of Food, Fisheries and Aquaculture Research (NOFIMA), N-9000 Tromsø, Norway. E-mail: frode.nilssen@ nofima.no. Personal communication 27 May and 1-3 June 2010.

Nordic Council of Ministers (2000), The Status of Fisheries and Related Environment of Northern Seas, a report prepared for the Nordic Council of ministers by ICES, Nord Fisheries 2000:10.

Norges Sildesalgslag. Landinger af sild i Norge. Tilgængelig på http://www. sildelaget.no/.

Norges Statistik. Lønstatistik, Statistisk Årbok 2009. Tilgængelig på http://www.ssb.no/.

NOTA. 2010. Regnskabsdata for den færøske fiskeflåde.

NOU 2000: 18. Skattlegging av petroleumsvirksomhet. Innstilling fra et utvalg oppnevnt ved kongelig resolusjon 22. oktober 1999.

Organisation of Economic Cooperation and Development (OECD). 2004. The Costs of Manageing Fisheries.

Organisation of Economic Cooperation and Development (OECD). 2005. Country note on national fisheries management systems - Norway. Retrieved 28 May 2010, from http://www.oecd.org/data oecd/10/9/34430920.pdf.

Organisation of Economic Cooperation and Development (OECD). 2010. Review of Fisheries in OECD Countiries. Information of Goverment financial transfers and costs of managing fisheries. General Survey p. 18. 
Paulrud A. 2006: The Resource Rent in Sweden's Fishery. IIFET 2006 Portsmouth Proceedings.

Pinkerton E., Edwards D.N., 2009 The elephant in the room: The hidden costs of leasing individual transferable fishing quotas. Marine Policy, 33(4): 707-713.

Scientific, Technical and Economic Committee for Fisheries (STECF). 2009. The 2009 Annual Economic Report on the European Fishing Fleet.

SEC 2004, The Potential Economic Impact on Selected Fishing Fleet Segments of TACs Proposed by ACFM, Report of the Scientific, Technical and Economic Committee for Fisheries, Subgroup on Economic Assessment, Brussels 27-29 October 2004, Commission Staff Working Paper, Brussels, 23.12.2004.

Skatteministeriet i Danmark. Indkomst- og selskabsbeskatning. Tilgængelig på http://www.skm.dk/.

Skatteministeriet i Norge, Indkomst- og selskabsbeskatning. Tilgængelig på http://www.skatteetaten.no/.

Statistics Iceland Icelandic. a. Landings of fish. Available at http://www.statice.is/.

Statistics Iceland Icelandic. b. Account Statistics. Available at http://www. statice.is/.
Statistics Iceland Icelandic. c. Statistics on labour earning. Available at http://www. statice.is/.

Stefán B. Gunnlaugsson, Ögmundur Knútsson og Jón Porvaldur Heiðarsson, 2010. Áhrif innköllunar aflaheimilda á stöðu íslenskra sjávarútvegsfyrirtækja.

Steinshamn, S.I. 2005, Ressursrenten i norske fiskerier, SNF rapport nr. 06/05.

UK Fisheries Department. Note on changes to the Fixed Quota Allocation system. Guidance Note FAQ5.

United Kingdom Statistics. Statistics on Labour Earnings. Available at http://www.statistics.gov.uk/.

Warming, J. 1911. Om grundrente af fiskegrunde, Nationaløkonomisk Tidsskrift, 49, 499-505.

Warming J. 1931. Aalegaardsretten, Nationaløkonomisk Tidsskrift, 69, 151-162.

Wiium, V.H. and Uulenga, A.S., 2003. Fishery management costs and rent extraction: The case of Namibia. In: Schrank, W.E., Arnason, R. and Hannesson, R. (eds.), The Cost of Fisheries Management. Ashgate, London, pp. 173-185.

World Bank and Food and Agriculture Organization, 2008:The Sunken Billions. The Economic Justification for Fisheries Reform. Agriculture and Rural Development Department. The World Bank. Washington 



\title{
English summary
}

\author{
Socio-Economic Return of Pelagic Fisheries in the \\ Northeast Atlantic Ocean
}

"There are too many fishermen to fish too few fish". This is the case in many fisheries. The consequence is that fishermen have low income, that the industry does not contribute to the national economy, that the public sectors costs of the industry exceeds revenue, and that supplies of fish are lower than it otherwise could have been, and at a higher price. That is the reason for the intensive focus on improving fisheries management worldwide. World Bank and FAO (2008) assesses in the report „The Sunken Billion", that the socio-economic returns in fisheries globally is negative. Thus, the costs of society of the existence of a fishing industry exceed revenue, which implies that the world's fisheries from a narrow cost-benefit consideration should be shut down. Several studies estimate that maximum socioeconomic returns of $40-50 \%$ can be achieved by good management (Nielsen et al 2006, World Bank and FAO 2008).

The present study is a contribution to the debate about how much the society can achieve in economic return of fisheries managed in accordance with a socio-economic objective. It focuses on pelagic fisheries with large vessels in the Northeast Atlantic Ocean, that is, fishing of mackerel and herring (Norwegian spring-spawning herring and North Sea herring) and the fish species used for reduction blue whiting, capelin and sand eel. Large vessels from Iceland, Norway, Faroe Islands, Denmark, United Kingdom and to a minor extent Russia is included. These fisheries have for years been well managed economically and can be viewed as „best practice". Individual transferable quotas are used in Iceland, the Faroe Islands and Denmark. Individual non-transferable quotas are used in Norway and the United Kingdom, where quotas implicitly are traded together with the vessel, implying that management in the two countries to some extent works like pure individual transferable quota systems.

The purpose of the study is to analyze how much well-managed and efficient fisheries, as the pelagic fisheries in the North East Atlantic Ocean, contributes to the socio-economy, and, to assess how the socio-economic returns possible can be increased through improved fisheries management. Furthermore, the purpose is to identify who benefits, how and to what extent it is possible to redistribute returns form the industry (owners of vessels and quotas, and crew) to the society. The desirability of redistribution is not assessed. 
The socio-economic return is defined as ,the surplus remaining after remuneration of capital and labor in excess of remuneration obtained in other businesses". The socio-economic return is measured with and without deduction of public expenditures on fisheries, including fisheries management costs and subsidies. The socio-economic return without deduction amounted to DKK 1.9 billion in 2007, or an average of $32 \%$ in the five vessel groups (Russia excluded), highest in the Icelandic vessel group with $43 \%$ and lowest in the Danish with $17 \%$. The socio-economic returns after deduction of these public expenses amounted to an average of $26 \%$.

The socio-economic returns are volatile in 2000-2008, but develop similarly across countries. The developments appear mainly from fluctuations in prices and fish stocks. The return is highest at the end of the period, lower in the beginning, and smallest in 2003-2004. The low yield in 2003-2004 is mainly due to low prices on herring and mackerel. The return of the five countries is stable or slightly rising. The socio-economic return in the Danish vessel group increased due to the in 2003-2007 introduced individual transferable quotas.

The maximum socio-economic returns in the long run are calculated in a bio-economic model with a series of assumptions about biology, economics, fleet structure, fisheries exploitation patterns and capacity utilization. With unchanged capacity utilization, the maximum socio-economic return, given that the quota allocation among countries remains unchanged, is on average $40 \%$ of the landing value. This represents an increase of $8 \%$; Largest in Denmark with $23 \%$, smallest in Norway where the return remains unchanged. If the quotas could be traded freely among individual vessels from different countries, corresponding to that the most efficient vessels purchase quotas from the less efficient, the maximum socio-economic return increase to an average of $43 \%$ of the landing value. If capacity utilization can be increased to 350 days for Icelandic vessels, to 300 for Faroese and to 250 for the others, corresponding percentages are $45 \%$ and $48 \%$, respectively. At an unchanged quota allocation among countries, this corresponds to an increase of $14 \%$; Largest in the United Kingdom with $29 \%$, smallest in Iceland where the return remains almost unchanged. Which capacity utilization is realistic should be assessed knowing that some management systems limit flexibility and that some fisheries are seasonal. The maximum socioeconomic return is estimated to lie somewhere between the two extremes.

The high current return reflects relatively efficient management of the analyzed pelagic fisheries. The fisheries policies emphasize socio-economic return, thereby giving less room for other possible purposes of the fisheries policies. The calculation also shows that there is scope for increasing the return through improved management, both nationally and through closer international cooperation. The largest increase can be achieved with improved national management (8-14\%), where the increase with closer international cooperation is modest (3\%). There is not assessed to be significant opportunities for improving fisheries management in countries with 
individual transferable quotas, i.e. Iceland, the Faroe Islands and Denmark. Additional gains may be achieved over time in Denmark and the Faroe Islands, without changing management, since the management there is relatively new. In Norway and the United Kingdom the flexibility of management can be enhanced by making quotas fully tradable, both permanently and temporarily, without vessels simultaneously being traded. The socioeconomic returns are also estimated to increase slightly through closer international cooperation, which allow individual vessels from the different countries freely to trade quotas.

The distribution of the socio-economic returns in 2007 between the owners of the vessels and quotas, the crew and the public sector indicates, that public authorities on average achieves $11 \%$ of the socio-economic returns. The public sector share is positive in all countries, Denmark excluded; Largest at the Faroe Islands with $21 \%$, at smallest in Denmark with -18\%. The negative public share of the socio-economic return in Denmark corresponds to that tax revenues are less than public expenditure on fisheries management and subsidies for that vessel group.

The crew obtains an average of $38 \%$. The crew share appear from salaries being from $85 \%$ higher than for the same number of hours worked in other businesses (Iceland and Denmark) to almost four times as high (United Kingdom). Part of the explanation for the higher salaries is the disadvantage of being at sea for long fishing trips, where the crew can work up to 12-14 hours a day.

Owners will have the remainder of the socio-economic return (on average $52 \%$ ); Highest in Denmark with $74 \%$ and smallest in Norway, with 40 $\%$. The current owners can have a substantial income from fishing. However, it might not be the case when the current owners have purchased quotas from former owners. Provided that they have paid the full price to the former owners, the owners' share of the socio-economic return have been given to previous generations of owners and removed from the industry. This is the case in countries where management has been in force for several years (Iceland, Norway, United Kingdom and partly the Faroe Islands). In Denmark, the present individual transferable quota system was introduced as late as in 2003-2007, implying that most of the income is estimated to be allocated to the current owners.

Improved fisheries management increases the socio-economic returns and with that the owners share. Whether the increases accrue to the current or previous owners depend on, whether the improvement was expected. Provided that it was expected, higher quota prices had appeared and the former owners receive the increase in the socio-economic return. If it was surprising, the increase accrues to the current owners. The crew will also obtain a part of the increase, if salary schemes remain unchanged. In the long run there will be fewer vessels and, thereby, less crew to share a fixed proportion of an increasing landing value. This gives the crew, who remain active, higher salary. 
With improved conditions for both owners and crew, tax revenues increase together with returns. The public sector share is, however, in several cases negative in bad years. That is, even though the Fisheries Law in several of the countries owning pelagic stocks states that the society owns the fish stocks, the public sector share of well-managed pelagic fish stocks are at best $1 / 5$ and on average $1 / 10$ of the socio-economic returns. In bad years the cost of management and subsidies exceed the tax revenues.

On this basis, the possibility of redistribution to the public sector is analyzed. If redistribution is desirable, it should necessarily be assessed together with efficiency. The reason is that when the management has been in force for long time, as in several of the pelagic fisheries, redistribution does some fishing vessels unprofitable, forcing efficient fishermen to leave the industry. The reason is that the return have been pulled out of the industry, since the current owners have paid the previous owners for their quotas. Thus, there is a trade-off between size and distribution of the socio-economic returns. If distribution changes, return can declines. Declines in socioeconomic returns as a result of redistribution can be avoided by applying the principle "the socio-economic returns can only be redistributed from those who have had it granted", thus limiting the possibility of redistribution to situations where the socio-economic returns are rising. That could either be as a result of improved fisheries management, as in the Danish pelagic fishery, or due to external factors such as price increases or improvements of fish stocks.

The socio-economic returns can be redistributed to the society through user fees and extra taxation. User can, for instance, be introduced through the removal of favorable arrangements for fisheries, including subsidies and fishermen deductions, by recover costs of fisheries management and through the sale of fishing rights at auctions. For instance, through reservation of a fraction of the total annual quota, which are subsequently sold at auction. Taxation instruments include taxes on landings, returns and on ownership of fishing rights.

Iceland is an example of a country that already has an extra tax on owners' returns. The experience is, however, that the charge has only charged a small part of the socio-economic returns. The reason is that there have been individual transferable quotas for many years, leading to that a large proportion of returns are in the hands of previous owners and are therefore not in the fishing industry anymore. The possibility of further redistribution without affecting efficiency is thus limited to a situation where the socioeconomic return increase as a result of, for example, price increases and improved fish stock conditions.

Denmark introduced recently, in 2003-2007, individual transferable quotas. With the recently changed management system the option of introducing redistribution through user fees on fish resources is present without vessels become unprofitable. But as time passes and the quotas are traded, the option diminishes. Conversely, according to the Fisheries Law, the manage- 
ment can always be terminated by notice eight years in advance, implying that an announced redistribution is always possible.

The Faroe Islands is to review the fisheries policy in 2018, which allows for redistribution. In Norway and the United Kingdom, the management has been in force for long time and the possibility of redistribution is limited to when the socio-economic returns are rising. Redistribution can, for example, be introduced simultaneously with that the flexibility of the quota system is increased by allowing sale of quotas, both permanently and temporarily, without simultaneous sale of the vessel.

It is emphasized that the findings in this report are based on a number of assumptions, both in relation to size and distribution of the socio-economic returns, and in identifying the maximum socio-economic returns. The results are therefore uncertain and should be interpreted with caution. 



\section{Bilag 1. Model}

\section{B.1.1 Det samfundsøkonomiske afkast}

Det samfundsøkonomiske afkast i den nuværende situation er for de enkelte fartøjsgrupper givet ved (1) og (2), før og efter fradrag af offentlige nettoudgifter til fiskeriet (henholdsvis type A og B).

$$
\begin{aligned}
& R_{o}^{A}=\sum_{i=1}^{n} L_{i}^{o} p_{i}+O T-V C_{o}-F C_{o} \\
& R_{o}^{B}=\sum_{i=1}^{n} L_{i}^{o} p_{i}+O T-V C_{o}-F C_{o}+U_{o}-S_{o}-M_{o}
\end{aligned}
$$

hvor $R_{o}^{A}$ og $R_{o}^{B}$ er det nuværende samfundsøkonomiske afkast henholdsvis før og efter fradrag af offentlige nettoudgifter til fiskeriet ud over andre erhverv, $L_{i}^{o}=$ landinger af den kvoterede fiskeart $i$ i udgangssituationen, $i=$ fiskeart hvor $i=1 . . . n, p=$ pris, $O T=$ anden indtægt og, $V C_{0}=$ variable omkostninger i udgangssituationen, herunder omkostninger til aflønning af arbejdskraft i alternativ anvendelse, $F C_{0}=$ faste omkostninger i udgangssituationen, herunder omkostninger til aflønning af kapital i alternativ anvendelse, $U_{o}=$ offentlige indtægter fra brugerbetaling i fiskeriet, $S_{o}=$ tilskud og $M_{o}=$ omkostninger til fiskeriforvaltning ${ }^{5}$.

\section{B.1.2 Det maksimale samfundsøkonomiske afkast}

Det maksimale samfundsøkonomiske afkast beregnes formelt i tre trin i en bio-økonomisk model, givet størrelsen af det samfundsøkonomiske afkast i udgangssituationen. Først identificeres i (3) - (7) totalomsætningen baseret på, at de biologiske muligheder udnyttes. Derefter findes omkostningerne i (8), og endelig beregnes det maksimale samfundsøkonomiske afkast i (9) (11).

Totalomsætningen ( $\mathrm{T}$ ) for den enkelte fartøjsgruppe er givet ved:

$$
T=\sum_{i=1}^{n} L_{i} p_{i}+O T
$$

Priser beregnes i løbende prisniveau og antages konstante, samtidig antages det, at anden indtægt $(O T)$ er konstant, herunder indtægt fra fangst af ikke kvoterede fiskearter ${ }^{6}$.

Produktionsfunktionen for den enkelte fartøjsgruppes fiskeri på kvoterede bestande er givet ved den mængde, der bæredygtigt kan udtages af bestanden: 
$L_{i}=q_{i}$, for $i=1 \ldots . n$ og $H>0$

$L_{i}=0$, for $i=1 \ldots n$ og $H=0$

hvor $q_{i}=$ den mængde af fiskeart $i$ den givne fartøjsgruppe bæredygtigt kan udtage af bestanden årligt, forudsat at fartøjsgruppen fisker en konstant andel af bestanden. $H$ = fiskeriindsats målt som antal fiskedage. Fiskeriet på de bestande, hvor der ikke eksisterer biologiske oplysninger, forudsættes at udvikle sig præcist som dem, hvor der eksisterer biologiske oplysninger.

Den biologiske produktionsfunktion er givet ved:

$q_{i}=f\left(X_{i}\left(H_{i}\right)\right)$, for $i=1 \ldots n$

hvor $X_{i}$ og $H_{i}$ er henholdsvis biomasse for og fiskeriindsats af en givet fartøjsgruppe på fiskeart $i$. Den biologiske produktionsfunktion angiver således, at den mængde fisk, der bæredygtigt kan udtages af bestanden, afhænger af biomasse, som igen afhænger af fiskeriindsats. Dvs. $q_{i}$ afhænger af både $X_{i}$ og $H_{i}$, men da der er en indbyrdes afhængighed mellem $X_{i}$ og $H_{i}$, modelleres $q_{i}$ som alene afhængig af $H_{i}$.

Den biologiske produktionsfunktion kan nu udspecificeres i to. Først specificeres sammenhængen mellem $q_{i}$ og $X_{i}$ i (6) og derefter sammenhængen mellem $X_{i}$ og $H_{i}$ i (7). Sammenhængen mellem $q_{i}$ og $X_{i}$ kan beskrives med følgende funktion:

$q_{i}=a X_{i} e^{-\left(b X_{i}\right)}$

hvor $a$ er en konstant og $b$ en elasticitet i den biologiske produktionsfunktion. Parametrene kalibreres for bestande, hvor der eksisterer biologiske vurderinger, givet viden om den nuværende biomasse, den maksimale biologiske biomasse og den betragtede fartøjsgruppes faktiske fiskeri på de enkelte bestande. Det antages endvidere, at hver af de analyserede fartøjsgrupper fisker en fast andel af fiskebestandene.

Sammenhængen mellem $X_{i}$ og $H_{i}$ specificeres ud fra, at ændringer i fartøjsgruppens fiskeriindsats anvendt til fiskeri efter fiskeart $i$ antages at afhænge af ændringer i biomassen som angivet i (7):

$$
\frac{X_{i, 1}}{X_{i, o}}=\beta\left(\frac{H_{i, 1}}{H_{i, o}}\right)^{-z}, \text { for } i=1 \ldots n
$$

hvor $H_{i, o}$ og $H_{i, 1}$ er antal fiskedage anvendt til fiskeri efter art $i$ henholdsvis i udgangsperioden og i en ny periode, hvor $X_{i, o}$ og $X_{i, 1}$ er biomassen for art $i$ henholdsvis i udgangsperioden og i en ny periode, hvor $\beta$ er en konstant, og hvor $z$ er en elasticitet, der angiver, hvordan bestanden påvirkes af ændret fiskeriindsats. Den funktionelle form angiver, at udviklingen i biomassen bestemmes af udviklingen i fiskeriindsatsen, givet biomasse og fiskeriind- 
sats i udgangssituationen. Dvs. ved en stor fiskeriindsats eksisterer en lille bestand og ved en lille fiskeriindsats opbygges på lang sigt en stor bestand. Som følge af at beregningen tager udgangspunkt i den nuværende biomasse og fiskeriindsats, beregnes den fremtidige fiskeriindsats under forudsætning af, at det nuværende niveau er bæredygtigt. Det antages endvidere, at $\beta=1$ for at simplificere modellen, samt at $z=1$, svarende til konstant skalaafkast. Hvis $z<1$, er der faldende skalaafkast og hvis $z>1$, er der stigende skalaafkast. Endelig antages da $H_{1}=\sum_{i=1}^{n} H_{i, 1}$ og $H_{o}=\sum_{i=1}^{n} H_{i, o} \quad$ at:

$\frac{H_{i, 1}}{H_{1}}=\frac{H_{i, o}}{H_{o}} \quad$, for $i=1 \ldots n$

(8) indebærer, at fartøjsgruppens relative fiskeriindsats målt ved fiskedage på de forskellige arter i en ny situation er det samme som i udgangssituationen.

Under forudsætning af (8) kan $X_{i}$ isoleres i (7) og indsættes i (6). $q_{i}$ i (6) kan endvidere indsættes $i$ (4a), givet at $H>0$, hvorved fartøjsgruppens totalomsætning i en ny situation, hvor der er taget højde for bestandsdynamikken, fremkommer ved at indsætte $L_{i}$ i (3).

Da beregningen foretages for det lange sigt, er alle omkostninger variable og omkostningsfunktionen for den enkelte fartøjsgruppe er givet ved (9) i en ny situation under antagelse af stigende faktorpriser.

$C_{1}=A\left(V C_{o}+\left(\frac{D S_{o}}{D S_{1}}\right) F C_{o}\right), \quad A=\alpha\left(\frac{H_{1}}{H_{o}}\right)^{(1+v)}$

$C_{1}$ er de totale omkostninger med aflønning af kapital og arbejdskraft i alternativ anvendelse, og FC i nærværende langsigtede model angiver de omkostninger, der knytter sig til det enkelte fartøj, uanset fartøjets aktivitet, og som på kort sigt er faste. Disse inkluderer kapitalomkostninger, afskrivninger og fartøjsomkostninger, som er uafhængige af, hvor meget det enkelte fartøj fisker. Disse omkostninger er i nærværende langsigtede model variable. $D S_{o}$ er antallet af fiskedage pr. fartøj pr. år i den nuværende situation, og $D S_{1}$ er antallet af fiskedage pr. fartøj pr. år i en ny situation. $\frac{D S_{0}}{D S_{1}}$ introduceres for at korrigere for kapacitetsudnyttelsen. A er en skaleringsfaktor for omkostningerne, der beskriver, hvor meget de ændrer sig, når den nuværende situation ændres til en ny. $\alpha$ er en konstant, og $\alpha>0$, da omkostningerne stiger med fiskeriindsatsen. $\alpha$ sættes for at simplificere til 1 . Omkostningerne i en ny situation beregnes således med udgangspunkt i det nuværende omkostningsniveau, korrigeret for ændret fiskeriindsats i fartøjsgruppen. $v$ er en parameter for forskellen i fiskernes effektivitet i anvendelsen af input faktorer. Når $v>0$, er nogle fiskere dygtigere end andre, hvilket medfører et økonomisk overskud (den infra-marginale rente, jf. Copes 1972), hvilket indebærer, at omkostningsfunktionen bliver konveks ${ }^{7}$. I nærværende artikel antages $v=$ $0,33 .^{8}$ Det antages, at omkostningerne pr. havdag er konstant. 
Det maksimale samfundsøkonomiske afkast uden fradrag af offentlige nettoudgifter til fiskeriet (type A) er for de enkelte fartøjsgrupper givet ved:

$$
R_{1}^{A}=\left(T_{1}-C_{1}\right)
$$

hvor $T_{1}$ er totalomsætningen i en ny situation, og $R_{1}^{A}=$ det samfundsøkonomiske afkast før fradrag af offentlige nettoudgifter til fiskeriet ud over andre erhverv i en ny situation. Det samfundsøkonomiske afkast efter fradrag af offentlige nettoudgifter til fiskeriet ud over andre erhverv (type B) beregnes ikke i en ny situation, da udviklingen i de offentlige nettoudgifter til fiskeriet ikke kendes eksakt.

I modellen bestemmes det maksimale samfundsøkonomiske afkast for fartøjsgrupperne totalt, idet det ikke giver mening at finde det totale samfundsøkonomiske afkast for hver national fartøjsgruppe, når fartøjsgrupper fra alle lande fisker på de samme bestande. Optimeringsberegningen foretages under antagelse af uændret flådestruktur og fiskerimønster og givet, at kvoterne er fast fordelt mellem fartøjsgrupperne fra hvert land. Den sidste antagelse indebærer, at hvert lands forvaltningsmyndighed regulerer fiskeriindsatsen således, at det maksimale samfundsøkonomiske afkast opnås for dette lands fartøjsgruppe. Dette benævnes national optimering. Derefter antages alternativt, at alle fartøjer kan handle kvoter frit med hinanden uanset nationalitet. Dette indebærer, at kun de mest effektive fartøjer forbliver aktive i fiskeriet og opkøber de øvrige fartøjers kvoter. Denne optimering benævnes international optimering, da den forudsætter mulighed for handel med kvoter mellem fartøjer fra forskellige lande. Endvidere bestemmes det maksimale samfundsøkonomiske afkast i de to scenarier vedr. den maksimale kapacitetsudnyttelse. I scenarie 1 antages, at fartøjernes fiskeriindsats er det gennemsnitlige antal fiskedage i det givne år (2007). I scenarie 2 antages en maksimal kapacitetsudnyttelse på 350 dage om året for de islandske fartøjer, 300 for de færøske og 250 for de danske, norske og britiske. Den maksimale kapacitetsudnyttelse er skønnet på grundlag af det faktiske antal fiskedage, at større fartøjer kan være længere på havet end små samt at jo mere industrifiskeri en fartøjsgruppe har, desto flere fiskedage vil det være nødvendigt at anvende.

Det maksimale samfundsøkonomiske afkast totalt for fartøjsgrupper fra alle lande og givet en fast fordeling af kvoter mellem lande bestemmes i scenarie 1 ved (11): 


$$
\begin{aligned}
& \underset{H 1 j}{\operatorname{Max}}\left(\sum_{j=1}^{m} R_{1 j}^{A}\right) \text {, givet } D S_{1 j}=D S_{0 j} \text {, og for } i=1 \ldots . n \text { og } j=1 \ldots m \\
& \text { for } H_{i, 1}>H_{i}^{M S Y} \text { er } \frac{L_{i j}^{0}}{\sum_{j=1}^{m} L_{i}^{0}}=\frac{L_{i j}^{1}}{\sum_{j=1}^{m} L_{i}^{1}} \text {, for } H_{i, 1} \leq H_{i}^{M S Y} \text { er } \frac{L_{i j}^{0}}{\sum_{j=1}^{m} L_{i}^{0}} L_{i}^{M S Y} \geq L_{i j}^{1}
\end{aligned}
$$

hvor $j$ angiver en national fartøjsgruppe og $m$ antallet af nationale fartøjsgrupper. (11) indebærer, at summen af det samfundsøkonomiske afkast $i$ alle de $m$ nationale fartøjsgrupper maksimeres ved at ændre på det totale antal fiskedage i hver fartøjsgruppe, givet at hvert fartøj i hver fartøjsgruppe fisker det samme antal dage om året som i 2007 og givet, at hver fartøjsgruppe ikke fisker mere end sin faste andel af den totale kvote, for alle de $m$ fartøjsgrupper (svarende til en fast kvotefordeling mellem lande). $L_{i}^{M S Y}$ og $H_{i}^{M S Y}$ angiver totale landinger og totale antal fiskedage på bestand $i$ hvis $H_{i}^{1}$ isoleres i (7), indsættes i (6) og maksimeres med hensyn til $H_{i}^{1}$ ved differentiation. Dette svarer til de totale landinger og det totale antal fiskedage som giver det maksimale vedvarende udbytte (MSY). Restriktionen angiver at hvis bestanden fiskes med flere fiskedage end hvad der giver det maksimale vedvarende udbytte, er totalfangsten begrænsende og mindst ét land fisker mere end kvoten hvis ikke fangsten er fast fordelt. Hvis bestanden derimod fiskes med færre fiskedage end dem der giver det maksimalt vedvarende udbytte er kvoten ikke begrænsende og hver fartøjsgruppe skal bare ikke fange mere end deres faste andel af det maksimale vedvarende udbytte.

(11) kan omskrives ved at indsætte (10) i (11) for alle $j$ og indsætte (9) for $C_{1}$ i (10). $X_{1}$ isoleres endvidere i (7) og indsættes i (6) under forudsætning af (8), som igen indsættes i (4) for $H>0$. $L_{i}$ indsættes i (3) for alle $i$, og endelig indsættes $T$ i (10). Herved fremkommer (12):

$$
\begin{aligned}
& \underset{H_{1 j}}{\operatorname{Ma}}\left(\sum_{j=1}^{m}\left(\sum_{i=1}^{n}\left(a \frac{X_{i, o} H_{i, o}}{H_{i, 1}} e^{-\left(b \frac{X_{i, o} H_{i, o}}{H_{i, 1}}\right)}\right) p_{i}+O T-\left(\frac{H_{1}}{H_{o}}\right)^{(1+v)}\left(V C_{o}+\left(\frac{D S_{o}}{D S_{1}}\right) F C_{o}\right)\right)\right) \\
& \text { givet } D S_{1 j}=D S_{0 j} \text { og } \frac{L_{i j}^{0}}{\sum_{j=1}^{m} L_{i}^{0}}=\frac{L_{i j}^{1}}{\sum_{j=1}^{m} L_{i}^{1}}, \text { for } i=1 \ldots n \text { og } j=1 \ldots m
\end{aligned}
$$

(12) viser totalomsætning minus totalomkostninger med aflønning af kapital og arbejdskraft $i$ alternativ anvendelse. I (12) er den totale fiskeriindsats for hver fartøjsgruppe $j$ i en ny situation ( $H_{1 j}=\sum^{n} H_{i, 1}$ for alle $j=1 \ldots m$ ) eneste variable led. Denne bestemmes ved maksimèi

Det maksimale samfundsøkonomiske afkast i scenarie 2 i den nationale optimering bestemmes som i (12), bortset fra, at $D S_{1 j}=D S_{0 j}$ erstattes af 
$D S_{1 j}=350,300,250$, hvor antallet af fiskedage $\left(D S_{1 j}\right)$ er 350 for de islandske fartøjer, 300 for de færøske og 250 for de øvrige.

Det maksimale samfundsøkonomiske afkast totalt for fartøjsgrupper fra alle lande i den internationale optimering, dvs. givet at fartøjer fra alle lande frit kan handle kvoter med hinanden, bestemmes i to trin. Først fordeles det totale antal fiskedage i udgangssituationen til de mest effektive nationale fartøjsgrupper, dvs. fiskedagene fordeles til de fartøjsgrupper, der i udgangssituationen opnår det største samfundsøkonomiske afkast. Herved opstår en ny fordeling af det totale antal fiskedage mellem fartøjsgrupper, for hvilket det maksimale samfundsøkonomiske afkast identificeres i den bioøkonomiske model (12), men uden binding på fordeling af kvoter mellem fartøjsgrupper.

Det samfundsøkonomiske afkast i udgangssituationen maksimeres i trin 1 ved omfordeling af fiskedage fra de mindst til de mest effektive nationale fartøjsgrupper, givet at hver fartøjsgruppes $j$ bruger en fast andel af fiskeriindsatsen på hver bestand.

$$
\underset{H_{j}^{\text {temp }}}{\operatorname{Max}}\left(\sum_{j=1}^{m} R_{0 j}^{A}\right), \quad \frac{L_{k}^{0}}{H_{j}^{0}}=\frac{L_{k}^{\text {temp }}}{H_{j}^{\text {temp }}} \quad \text { givet og } \sum_{j=1}^{m} H_{j}^{0}=\sum_{j=1}^{M} H_{j}^{\text {temp }}
$$

for $j=1 \ldots . m$ og $k=1 \ldots l$

hvor $H_{j}^{\text {temp }}$ angiver det antal fiskedage hver fartøjsgruppe $j(j=1 \ldots . m)$ i en ny midlertidig (temporær) situation skal fiske for at nå det nye midlertidige maksimale samfundsøkonomiske afkast, givet at det totale antal fiskedage er konstant, men fordelt anderledes mellem fartøjsgrupper, og givet at fangst per fiskedag er konstant.

Da alle beregninger gennemføres for en uændret omkostningsstruktur er antaget, at andelen af fangst af forskellige arter er konstant. Men da ikke alle fartøjsgrupper nødvendigvis fisker på alle bestande, indebærer en omfordeling af fiskedage til de mest effektive fartøjer at der ikke nødvendigvis bliver fiskeri på alle bestande. Derfor introduceres tre typer af fisk; makrel, sild (norsk vårgydende sild og sild i Nordsøen), samt industrifisk (blåhvilling, lodde og tobis). Fisketype betegnes $k$ og $k=1 . . . l$, hvor $l=3$. Introduktionen indebærer en implicit antagelse om, at omkostningerne i fiskeri efter norsk vårgydende sild og sild i Nordsøen er ens, samt om at omkostningerne i fiskeri efter blåhvilling, lodde og tobis er ens. Restriktionen $\frac{L_{k}^{0}}{H^{0}}=\frac{L_{k}^{\text {eemp }}}{H^{\text {temp }}}$ indebærer således, at fangsten af fisketype $k$ per fiskedag er konstant sámt at fordelingen af fangsten mellem fisketyper er konstant for alle de $j$ fartøjsgrupper. $H_{j}^{\text {temp }}$ bestemmes ved anvendelse af Problemløser funktionen i Excel.

For de nye midlertidige antal fiskedage maksimeres det samfundsøkonomiske afkast i den bio-økonomiske model uden binding på fordeling af kvoter. Dette er den internationale optimering, hvor fartøjer fra forskellige lande frit kan handle kvoter med hinanden. Den internationale optimering 
beregnes ud fra (12), idet der dog optimeres med udgangspunkt i fordelingen af fiskedage $H_{1 j}^{\text {temp }}$ i stedet for $H_{1 j}$ såvel som der ikke som i (12) er bindinger på fordelingen af fangsten mellem nationale fartøjsgrupper. Det maksimale samfundsøkonomiske afkast i denne situation fremgår af (14) for scenarie 1.

$\underset{H_{1 j}^{\text {temp }}}{\max }\left(\sum_{j=1}^{m}\left(\sum_{i=1}^{n}\left(a \frac{X_{i, o} H_{i, o}}{H_{i, 1}} e^{-\left(b \frac{X_{i, o} H_{i, o}}{H_{i, 1}}\right)}\right) p_{i}+O T-\left(\frac{H_{1}}{H_{o}}\right)^{(1+v)}\left(V C_{o}+\left(\frac{D S_{o}}{D S_{1}}\right) F C_{o}\right)\right)\right)$

givet $D S_{1 j}=D S_{0 j}$ for $i=1 \ldots n$ og $j=1 \ldots m$

I scenarie 2 i den internationale optimering bestemmes det maksimale samfundsøkonomiske afkast som i (14), bortset fra at $D S_{1 j}=D S_{0 j}$ erstattes af $D S_{1 j}=350,300,250$, hvor antallet af fiskedage $\left(D S_{1 j}\right)$ er 350 for de islandske fartøjer, 300 for de færøske og 250 for de øvrige.

Det identificerede maksimale samfundsøkonomiske afkast kan være både under- og overvurderet. Således er antaget at den relative fiskeriindsats på hver bestand er fast. Antagelsen er nødvendig, da der alene haves regnskabsdata for hele år og ikke for hver fangsttur, men konsekvensen er, at fartøjerne ikke kan indrette sig optimalt og fx ikke kan begynde at fiske på ellers uudnyttede industriarter, hvis fiskeriet af andre arter begrænses. Dette er urealistisk og indebærer, at det reelle maksimale samfundsøkonomiske afkast er undervurderet. Endvidere betragtes i beregningen alene gennemsnitsfartøjer i hvert af fartøjsgrupperne, og resultatet er, at kun nogle få fartøjsgrupper forbliver aktive. Dette er ikke realistisk, idet de mest effektive fartøjer fra hver national fartøjsgruppe vil forblive aktive. Konsekvensen er, at det maksimale samfundsøkonomiske afkast også af denne grund undervurderes, idet det vil blive de mest effektive fartøjer der forbliver aktive, og ikke kun, som antaget i beregningen, de mest effektive gennemsnitsfartøjer.

Omvendt vil det maksimale samfundsøkonomiske afkast være overvurderet, såfremt fiskeridødelighedsniveauerne ikke er bæredygtige. Er de derimod bæredygtige, påvirkes præcisionen i bestemmelsen af det samfundsøkonomiske afkast ikke.

\section{B.1.3 Fordeling af det samfundsøkonomiske afkast}

Fordelingen af det samfundsøkonomiske afkast efter fradrag af offentlige nettoudgifter til fiskeriet (type B) identificeres ved at beregne andelen for kapitalen og arbejdskraften i fartøjsgruppen og den offentlige sektor, som angivet i (15) - (17).

$$
w_{L}=\frac{\left(L I_{F}-T_{F}^{I}-L I_{A}+T_{A}^{I}\right)}{R_{0}^{B}}
$$




$$
\begin{aligned}
& w_{K}=\frac{\left(\pi-T_{F}^{C}-K I_{A}+T_{A}^{C}\right)}{R_{0}^{B}} \\
& w_{G}=\frac{\left(T_{F}^{I}-T_{A}^{I}\right)+\left(T_{F}^{C}-T_{A}^{C}\right)+U+S+M}{R_{0}^{B}}
\end{aligned}
$$

hvor $w_{L}, w_{K}$ og $w_{G}$ er henholdsvis arbejdskraftens, kapitalens og den offentlige sektors andel af det samfundsøkonomiske afkast i fartøjsgruppen, $L I_{F}=$ total aflønning af arbejdskraft i fartøjsgruppen, $L I_{A}=$ total aflønning af fartøjsgruppens arbejdskraft i alternativ anvendelse, $\pi=$ overskud i fartøjsgruppen, $K I_{A}=$ alternativ forrentning af den kapital, der er investeret i fartøjsgruppen i form af afkast eller overskud, og hvor $T_{F}^{I}, T_{A}^{I}, T_{F}^{C}$ og $T_{A}^{C}$ er betalt skat fra henholdsvis arbejdskraften i fartøjsgruppen, fartøjsgruppens arbejdskraft i alternativ anvendelse, kapitalen investeret i fartøjsgruppen og fartøjsgruppens kapital investeret alternativt. 


\title{
Bilag 2. National forvaltning
}

\author{
B.2.1. Island
}

Fiskeriet

I Island udgør det pelagiske fiskeri størstedelen af landets samlede fangstmængde. De vigtigste bestande er lodde, sild og blåhvilling, og makrel er de seneste år også blevet en vigtig art, men er ikke inkluderet i dette studie. Fiskebestandene hører ikke udelukkende til i islandsk farvand, men migrerer rundt i hele Nordøstatlanten, som f.eks. den norske vårgydende sild. Forvaltningen af bestandene sker i samarbejde med nabolandene Norge, Færøerne, Danmark, Grønland og EU.

\section{Forvaltningen}

Hvert år fastsættes den totale tilladte fangstkvote (TAC) for Island af fiskeriministeren, og TAC'en deles ud på de pelagiske fartøjer som kvoter. Dette kvotesystem er den vigtigste forvaltningsmetode for fiskeriet i Island. Kvotehandlen er fri, så fartøjsejere kan købe og sælge kvoter frit. Det bør nævnes, at det islandske fiskeri introducerede individuelle kvoter i 1979 og var blandt de første til at blive reguleret via kvoter.

I følge det Islandske Havforsknings Institut har de pelagiske bestande været stabile, selvom loddefiskeriet har været for nedadgående de seneste år.

Fangsten landes i havnene i det sydlige, østlige og vestlige Island. Sild bruges til konsum mens lodde og blåhvilling er industrifisk der forarbejdes til fiskemel.

Det islandske fiskeri er eksportorienteret. De fleste fartøjer er ejet af store virksomheder og indgår i virksomhedens flåde. Nogle virksomheder ejer også forarbejdningsfabrikkerne på land, som også de privatejede fartøjer sælger deres fangst til.

De pelagiske fiskerier er reguleret ved det individuelt omsættelige kvotesystem, som nævnt ovenover. Systemet blev introduceret i 1979 og er nu veletableret. Hver fartøjsejer ejer en andel af landets TAC, som de frit kan sælge. Fiskeridirektoratet forvalter landets TAC, såvel som andre forvaltningsmetoder som f.eks. lukning af områder eller redskabsrestriktioner. Det vigtigste kontrolmiddel, som det islandske fiskeridirektorat har til rådighed, er de obligatoriske fiskerilogbøger, som jævnligt kontrolleres.

Fiskeriministeren fastsætter den islandske TAC hvert år på grundlag af råd fra det Islandske Havforsknings Institut. Hovedforvaltningsmålet er et bæredygtigt fiskeri, som maksimerer det bæredygtige samfundsøkonomiske 
afkast, men også andre aspekter som internationale aftaler påvirker størrelsen af den islandske TAC.

Der er tre love, som vedrører forvaltningen af fiskeriet i den islandske eksklusive økonomiske zone, er; Fisheries Management Act, No. 116/2006, Treatment of Exploitable Marine Stocks Act, No. 57/1996, og Fishing in Iceland Fisheries Jurisdiction Act, No. 79/1997. De bestemmer alle regler, som gælder for både pelagiske og demersale fiskerier.

Alle disse love indeholder næsten identiske paragraffer omhandlende straf. Overtrædelser kan medføre skriftlige reprimander, tilbagekaldelse af fiskerilicenser, bøder og fængsel i op til seks år, afhængigt af overtrædelsens grovhed. Det er det islandske fiskeridirektorat, som udsteder reprimander, bøder og tilbagekalder fiskerilicenser. Straffen for første krænkelser er mildere end straffen for gentagne overtrædelser. Omfanget af den periode, hvor fiskerilicensen tilbagekaldtes, afhænger af, hvor alvorlig overtrædelsen har været. Det kan være alt fra en uge til permanent fratagelse af licensen. Den maksimale bøde for første overtrædelse er 4.000.000 ISK, mens minimumsbøden er på 400.000 ISK. Ved gentagende overtrædelser hæves den maksimale bøde til 8.000.000 ISK. Desuden er der en klausul i alle tre bestemmelser, som tillader en særlig bøde ved ulovlig fangst, hvilken er udstedt på grundlag af lov 37/1992. The Fishing in Iceland Fisheries Jurisdiction Act, No. 79/1997, indeholder desuden et afsnit (§ 16) der giver mulighed for konfiskation af ulovlige fangstredskaber.

To offentlige instanser er i princippet ansvarlige for overvågningen af fiskeriet, nemlig fiskeridirektoratet og kystvagten. Fiskeridirektoratet kontrollerer fiskerilogbøgerne og udfører inspektioner, mens kystvagten overvåger fangstredskaber og lukkede områder via skib og fly.

TAC'ere fastsættes for Island af fiskeriministeren efter anbefaling fra det Islandske Havforskningsinstitut. Den årlige kvote (aflamark, målt i tons) bestemmes ude fra fartøjets permanente kvoteandel (aflahlutdeild, målt som andel af TAC'en) og TAC'en. Fartøjerne kan øge deres årlige kvote ved at købe kvote fra andre fartøjer. Den permanente kvoteandel er den egentlige varige kvote. Fiskeridirektoratet har tilsyn med alle fartøjers beholdning af kvoter. Det er fri handel både med permanente og årlige kvoter. Fiskeri udenom den årlige kvote er forbudt. Alle fangster må vejes af registreret havnevægt og fangsten må rapporteres til Fiskeridirektoratet. Alle fartøjer må i tillæg hertil have gyldig licens fra Fiskeridirektoratet.

Fiskeridirektoratet fører tilsyn med obligatoriske fiskerilogbøger. Der findes ingen særregler herom for bestemte fartøjsgrupper, heller ikke for den pelagiske fartøjsgruppe. 


\section{B.2.2. Norge}

Fiskeriet

Fartøjsgruppen, som fisker efter de pelagiske arter, består af tre forskellige undergrupper, kystfartøjerne, som er mindre end 27, 5 m, de pelagiske trawlere og notfartøjerne. Nogle notfartøjer har en ekstra licens, som giver dem tilladelse til at fange blåhvilling med trawl, og denne fartøjsgruppe repræsenterer Norge i dette studie.

Notfartøjerne med licens til blåhvillingtrawl fanger mange forskellige arter af fisk, hvor de mest vigtige er sild, lodde, makrel og blåhvilling, både i forhold til mængde og værdi. Sild fanges fra den norske vårgydende sildebestand, samt fra Nordsøbestanden.

Fangsten af sild, blåhvilling og makrel sker i Norskehavet samt i Nordsøen. Lodde fanges i Barentshavet og ved Jan Mayen mellem Island og Grønland. Fangsten sker inden for den norske eksklusive økonomiske zone, andre nordatlantiske landes zoner samt i internationalt farvand.

\section{Forvaltningen}

Som følge af lovgivningen fra 1999 „, Deltagelse i fiskerierne“ skal alle, som deltager i det kommercielle fiskeri, have en licens (tilladelse uden tidsbegrænsning) eller en årlig tilladelse. De små kystfartøjer, som fisker med traditionelle fiskeredskaber, er fritaget for licenspligt, selvom deres adgang til fiskeriet er reguleret gennem årlige tilladelser. Licensen repræsenterer rettigheden til at deltage i et bestemt fiskeri. Den er kun gyldig for en ejer på et bestemt fartøj og er i princippet ikke omsættelig. Dog er der undtagelser. Når fartøjerne sælges, følger licenserne med til den nye ejer. En ejer kan også overføre sin licens fra et skib til et andet, så længe skibet, licensen er taget fra, fjernes fra fiskeriet.

For de vigtigste bestande opdeles den norske TAC i gruppekvoter, som stemmer overens med de forskellige grupper af fartøjer med licens. Gruppekvoten er for nogle fiskerier fordelt ligeligt mellem fartøjerne, mens de for andre fiskerier fordeles på baggrund at fartøjslængden, tonnage eller andre tekniske kriterier. For notfartøjerne uddeles der individuelle fartøjskvoter for alle målarterne.

individuelle fartøjskvoter er ikke omsættelige i den forstand, at de hverken kan udlejes eller sælges. Dog følger, som med licenserne, kvoterne fartøjerne, når de bliver solgt. Derudover etablerede Norge et strukturforvaltningssystem i 1996 for et antal fartøjsgrupper gennem et kvotetransfer system, kaldet enhedskvotesystemet. Systemet tillader ejeren af flere fartøjer at fiske alle fartøjernes kvoter fra et enkelt fartøj, så længe de andre fartøjer er taget ud af fiskeriet. Hvis en fartøjsejer køber endnu et fartøj, kan han fange begge kvoter i en periode på 13 år, men hvis det nyindkøbte fartøj ophugges, kan ejeren fisker med begge kvoter i 18 år. Baggrunden for denne 
ide var at reducere antallet af fartøjer i bestemte grupper, hvor fiskekapaciteten blev vurderet til at overstige nuværende og fremtidige TAC'ere. Notfiskeriet blev inkluderet i enhedskvotesystemet, men fra 2005 blev enhedskvotesystemet erstattet af et strukturelt kvotesystem for havflåden. Forskellen mellem disse to er, at det strukturelle kvotesystem ikke har en forudbestemt tidsbegrænsning (OECD 2005).

Der er et generelt forbud mod udsmid, og for makrel, norsk vårgydende sild, nordsøsild og skagerraksild er der også et forbud mod udsmid af fiskeaffald. For hvert fiskeri er der en række tillægsrestriktioner omhandlende bifangst, minimumsstørrelser, maskestørrelser, udstyr osv. Disse typer af forvaltning varierer fra art til art og fra fartøjsgruppe til fartøjsgruppe. Kun restriktionerne omhandlende fartøjsgrupperne vil blive beskrevet i det følgende.

Når den nationale TAC for sild, lodde, blåhvilling og makrel er fastlagt $\mathrm{i}$ en aftale med de relevante deltagere, vil landets TAC blive fordelt mellem de forskellige fartøjsgrupper; kystfartøjer, trawlere og notfartøjer. Tabel A1 viser den procentvise fordeling af den norske TAC for notfartøjerne opdelt på de relevante arter i 2008.

Tabel B1. Notfartøjernes andel af den norske TAC fordelt på forskellige arter i 2008.

\begin{tabular}{lc}
\hline Bestand & Andel af TAC (\%) \\
\hline Norsk vårgydende sild & 52,2 \\
& 77 \\
Lodde i Barentshavet & Ingen kommerciel fangst \\
Lodde i Grønland-Island-Jan Mayen området & 100 \\
Makrel & 68,35 \\
Blåhvilling & 78 \\
\hline
\end{tabular}

Kilde: Fiskeridirektorat i Norge (b).

Gruppekvoten bliver delt op i individuelle fartøjskvoter. Fordelingen af individuelle kvoter for fartøjsgruppen er her fordelt på baggrund af licenserne fundet ud fra fartøjsstørrelserne og kvoterettigheder opnået gennem enhedskvotesystemet eller det strukturelle kvotesystem. Kvoten fordelt på baggrund af licens afgøres ud fra fartøjsstørrelsen og udregnes på baggrund af følgende:

$1500 \mathrm{hl}+40 \%$ af licensbaseret kapacitet mellem 0-4000 hl

$30 \%$ af licensbaseret kapacitet mellem 4000-6000 hl

$20 \%$ af licensbaseret kapacitet mellem 6000-10 $000 \mathrm{hl}$

$10 \%$ af licensbaseret kapacitet mellem $10000 \mathrm{hl}$.

Fartøjsstørrelsen konverteres til tons ved følgende formel $1 \mathrm{hl}=0,1$ tons. Mængden fundet via denne metode samt andre rettigheder opnået via enhedskvotesystemet eller det strukturelle kvotesystem refereres der til som basiskvoten. Den faktiske kvote er fundet ved at gange basiskvoten med kvotefaktoren. For norsk vårgydende sild, nordsøsild, makrel og lodde er kvotefaktoren lig med gruppekvoten delt med summen af basiskvoten for alle fartøjer i gruppen som deltager i fiskeriet. For blåhvilling er kvotefaktoren 1 for de fleste af fartøjerne. For de fleste arter bliver de individuelle kvo- 
ter opdelt i tilladt fangst pr. fartøj i et givent område for at beskytte underbestandene mod overudnyttelse.

De fleste fartøjer i fartøjsgruppen har brugt muligheden for at øge deres basiskvote gennem brugen af enhedskvotesystemet. I dag er den gennemsnitlige basiskvote, som omfatter de licensbaserede fartøjer på 480 tons, mens den gennemsnitlige totale basiskvote er 584 tons.

Som tilføjelse til kvoter reguleres der via minimumsstørrelser for målarterne og en maksimum bifangst. Tabel A2 viser minimumsstørrelser for målarterne og den maksimale bifangst tilladt for vigtigste arter for fartøjsgruppen.

Tabel B2. Oversigt over minimumsstørrelser for målarterne og den maksimale bifangst

\begin{tabular}{lll}
\hline Fiskebestand: & $\begin{array}{l}\text { Minimum } \\
\text { Fiskestørrelse: }\end{array}$ & Maksimale tilladt bifangst \\
\hline Makrel & 30 & $10 \%$ \\
Norske vårgydende sild & 25 & $20 \%$ \\
Nordsøsild & 20 & $10 \%$ \\
Skagerraksild & 18 & $10 \%$ \\
Lodde i Barentshavet & 11 & $10 \%$ og 300 individer pr. tons lodde af hver af arterne \\
& & under minimumstørrelsen; \\
& & torsk, kuller, sild, grønlandsk helleflynder \\
Lodde ved i Jan Mayen & 12 & $10 \%$ og 300 individer pr. tons lodde af hver af arterne \\
& & under minimumstørrelsen; \\
& & torsk, kuller, sild, grønlandsk helleflynder \\
\hline
\end{tabular}

Kilde: Fiskeridirektorat i Norge (b).

Når bifangst grænserne overstiges, eller når en stor del af fangsten er under minimumsstørrelsen, lukkes et område for fiskeri. For en stor del af perioden har den nordøstlige del af den norske eksklusive økonomiske zone været lukket for fangst af norsk vårgydende sild, grundet for store fangster af alt for unge fisk.

\section{B.2.3. Færøerne}

Fiskeriet

Det færøske pelagiske fiskeri er for en meget stor del koncentreret omkring sild, makrel og blåhvilling. Især sildefiskeriet har en lang historie på Færøerne, med sildefiskeri fra 1950'erne. Sildefiskeriet forsvandt næsten i 1970 'erne og kom først rigtige i gang igen i midten af 1990'erne. En aftale mellem kyststaterne om sildefiskeriet blev indgået i 1996. Makrelfiskeriet har også en lang historie, og omkring 2000 blev også det reguleret med internationale kvoter. Det færøske fiskeri efter makrel foregår næsten udelukkende i norsk farvand, og fiskeriet efter sild foregår også primært i norsk farvand, men der fiskes også i færøsk farvand. Vedrørende blåhvilling er historien, at i 1980'erne blev der eksperimenteret med at fiske blåhvilling, men det var først omkring 2000, at der blev sat rigtigt gang blåhvillingfiske- 
riet med færøske fartøjer. Før det tidspunkt havde russiske fartøjer fisket blåhvilling igennem 1980’erne og 1990'erne i færøsk farvand. Det færøske fiskeri efter blåhvilling foregår i EU farvand ud for Irland og Storbritannien samt i færøsk farvand.

Færøerne er en del af det danske rigsfællesskab, dog med fuldt selvstyre på fiskeriområdet. Færøerne er en selvstændig del af de internationale aftaler om sild, makrel og blåhvilling. Dette er også begrundet i, at Færøerne ikke er en del af EU. Færøerne har omkring $25 \%$ af blåhvillingkvoten, mens de har omkring 5 \% af den samlede silde- og makrelkvote. Når kvoten er delt mellem kyststaterne, deler Færøerne en stor del af deres samlede kvote med Rusland til gengæld for at kunne fiske torsk og kuller i Barentshavet, mens russere fisker blåhvilling og makrel i færøsk farvand. Igennem årene er omkring halvdelen af den færøske blåhvillingkvote og omkring halvdelen af makrelkvoten givet til russiske fartøjer.

Russiske fartøjer fisker blåhvilling og makrel til konsum. De færøske fartøjers fiskeri af blåhvilling er næsten udelukkende til industri. De færøske fartøjers fangst af sild og makrel er til gengæld næsten udelukkende gået til konsum i perioden.

Der er to fabrikker på Færøerne, der kan tage imod fisk fra de pelagiske fartøjer. Den ene er en fiskemelsfabrik, som har eksisteret siden 1960'erne. Denne fabrik har taget imod en stor del af det færøske fiskeri efter blåhvilling. Den anden fabrik har eksisteret i et par år og kan tage imod fisk til konsum, men har begrænset kapacitet. Derfor bliver det meste af det pelagiske fiskeri efter sild og makrel landet til norske opkøbere.

For at kunne fiske makrel og sild i norsk farvand indgår Færøerne og Norge bilaterale aftaler med hinanden om gensidigt fiskeri. Norge fisker bl.a. blåhvilling i færøsk farvand. Færøerne og Island har også vidtrækkende aftaler om fri adgang hos hinanden til at fiske den samlede kvote for disse arter. Endelig har EU og Færøerne bilaterale aftaler om begrænset adgang til fiskeri i hinandens farvande.

På Færøerne er der er kun 8 notfartøjer, og disse er fordelt på kun 3 rederier, men alle 8 fartøjer er til gengæld store fartøjer. Udover disse er der mellem 1 og 3 fartøjer i perioden 2000-2008, der går under betegnelsen industritrawlere, og disse fisker især blåhvilling. Fartøjerne i case studiet dækker over 80 $\%$ af den samlede landingsværdi for færøske fartøjer af disse arter.

\section{Forvaltningen}

Forvaltningen af det færøske fiskeri er både med kvoter og tekniske reguleringer. En anden regulering er licenser. Der er ikke givet nye licenser til pelagiske fartøjer i perioden.

Blåhvilling: For årene 2000 til 2005 var fiskeriet frit, da der i disse år ikke var nogen international kvote for blåhvilling. Fra 2006 til 2008 var der fastsat et samlet TAC, og fiskeriet foregik efter 'først til mølle' princippet. I 2009 blev der indført et individuelt omsætteligt kvotesystem for blåhvilling- 
fiskeriet. Kvotetildelingen var især baseret på historiske fangster for en 10årig periode. Bestanden af blåhvilling er nu langt lavere end tidligere. Kvoterne af blåhvilling i 2009 er kun en fjerdedel af, hvad de var omkring 2006.

De tekniske reguleringer i blåhvillingfiskeriet i færøsk farvand har betydet, at der ikke kan fiskes i de indre farvande omkring Færøerne. Maskevidden i trawlene skal være større end $35 \mathrm{~mm}$. Trawlet skal også have installeret en rist (fra 2007), således at bifangsten bliver så lille som mulig. Samlet skal bifangsten af bundfisk (torsk, kuller, sej og rødfisk) være under $2 \%$ af den samlede fangst.

Sild og makrel: Det meste af dette fiskeri foregår ved Norge, så disse fartøjer er omfattet af norske regler (jf. bilag B2.2). Fiskeriet omkring Norge er oftest med not, mens fiskeriet omkring Færøerne er med trawl. Da der er fiskeri inden for færøsk zone (især efter sild), er der regler om, at trawl ikke benyttes indenfor 12 sømil grænsen omkring Færøerne. Dette er i overensstemmelse med anden trawl forvaltning på Færøerne. Der er ligesom for blåhvilling også regulering, der forbyder brugen af små masker i trawlet, samt regler om bifangst.

Desuden er der internationale aftaler om forbud imod discard i disse fiskerier. Dette omfatter både selve fisken og affald i forbindelse med forarbejdningen.

For alle årene har fiskeriet efter sild og makrel været reguleret ved individuelt omsættelige kvoter. Dette betyder, at hvert fartøj har fået en del af den samlede kvote, som frit har kunnet handles mellem de 8 fartøjer, Men har ikke kunnet sælges uden for gruppen og heller ikke til udenlandske fartøjer. Vedrørende udenlandsk ejerskab kan højst $33 \%$ af den samlede egenkapital af virksomhederne bag fartøjerne være udenlandsk.

Kvoterne blev uddelt til fartøjerne ud fra historisk fiskeri. Kvoterne for et af disse fartøjer (omfattende sild, makrel og blåhvilling) blev solgt i 2006 sammen med fartøjet. Dette gav en gevinst for kvoterne på omkring 250 mio. DKK. Dette viser, at værdien af kvoterne er kapitaliseret, men den er kun blevet realiseret for et af de 8 fartøjer. For de øvrige fartøjer er kvoten stadig i de oprindelige ejeres hænder.

\section{B.2.4. Danmark}

\section{Fiskeriet}

Det pelagiske danske fiskeri er rettet mod konsumarterne sild og makrel samt en række industriarter, hvoraf de vigtigste er tobis, brisling, sperling, blåhvilling og hestemakrel. Industrifiskeriet og fiskeriet efter makrel foregår overvejende i Nordsøen, mens sildefiskeriet udover Nordsøen også er vigtigt i Norskehavet samt til en vis grad i Østersøen. Både sild og makrel såvel som størstedelen af industriarterne fiskes i dag fra fartøjer over 40 meter med enten not eller trawl. 


\section{Forvaltningen}

Den væsentligste forvaltning af fiskeriet er kvoter. Alle de her nævnte arter er omfattet af kvoter, som siden 1983 er blevet bestemt af den fælles fiskeripolitik. De årlige kvoter er således et resultat af EU's samlede tilladte fangstmængde for arterne og det faste kvotefordelingssystem mellem landene samt fiskeriaftaler med landene uden for EU, heriblandt Norge, Island og Færøerne. De danske kvoter har været stabile for makrel i hele den behandlede periode, hvorimod de har været faldende for sild siden 2005, og generelt set har de svinget betydeligt for industrifiskene. I den første halvdel af årtiet var både silde- og industrifiskekvoterne omtrent dobbelt så høje som i dag. Årsmængder for de enkelte fartøjer beregnes ud fra kvoteandele, som er tilknyttet disse, hvilket siden 2003 i stadig stigende omfang for de pelagiske arter er blevet bestemt af de individuelle overdragelige kvoter (jf. nedenfor).

En anden betydende del af forvaltningen består af en adgangsbegrænsning samt en forvaltning af fartøjsgruppens samlede kapacitet målt i tonnage og motorkraft. Der kræves erhvervsfiskerstatus for at opnå adgang til at drive fiskeri. Desuden kræves, at det anvendte fartøj er registreret som erhvervsfiskerfartøj i det danske register over fiskerfartøjer. Reglerne er blevet skærpet i forbindelse med EU's reviderede fiskeripolitik i 2003. EU fastsætter referencelofter for fartøjsgruppens kapacitet målt i bruttotonnage (BT) og motorkraft $(\mathrm{kW})$. For den danske fartøjsgruppe har dette ikke nogen stor betydning, da kapaciteten allerede var reduceret betydeligt mere end EU's loft. Der er blevet gennemført en restriktiv politik på dette område i Danmark gennem en årrække, hvor nye fartøjer skal opkøbe kapacitet hos eksisterende fartøjer for at få adgang til fiskeri. Hvis fartøjer tages ud med ophugningstilskud, skal kapacitetslofterne reduceres tilsvarende. Ydermere gælder, at hvis der indsættes nye fartøjer over 100 BT med tilskud, skal kapacitetslofterne reduceres med $35 \%$ af den indsatte BT og kW.

En direkte forvaltning af fiskeriindsatsen foregår via systemet med havdage/kilowattdage og siden 2003 i form af en begrænsning i antal havdage for de enkelte fartøjer og pr. 1. februar 2009 som kilowattdage, der er havdage i relation til motorkraften på skibet. Ordningen gælder dog ikke for det pelagiske fiskeri.

Overdragelighed af fiskerirettighederne, hvilket i denne sammenhæng vil sige kvoteandelene, er et andet centralt element i fiskeriforvaltningen. Det pelagiske fiskeri er i Danmark nu i alt væsentlighed overgået til individuelle omsættelige kvoter. Overgangen til det individuelt omsættelige kvotesystem blev indledt i starten af 2003, hvor sildefiskeriet i Nordsøen, Skagerrak og Kattegat samt fiskeri efter norsk vårgydende sild blev reguleret med individuelle omsættelige kvoter. Makrelfiskeriet overgik til omsættelige kvoter i 2007, mens industrifiskeriet overgik til det individuelt omsættelige kvotebaserede system fra starten af 2007. Endelig som den sidste del af det pelagiske fiskeri ændrede industrifiskeriet efter brisling i Kattegat og Østersøen samt fiskeriet efter sild i Østersøen status til individuelt omsættelige kvoter fra 1. januar 2008. I den mellemliggende periode fra og med den anden 
halvdel af 2004 blev der indført en slags overgangsordning for makrelfiskeriet og visse dele af industrifiskeriet i Nordsøen, som omfattede individuelle ikke-omsættelige kvoter.

I praksis betyder de individuelle omsættelige kvoter, at disse kan handles. En enkelt ejer må dog maksimalt være i besiddelse af $10 \%$ af hver kvote. Der afsættes imidlertid også hvert år en mindre mængder af kvoterne til andre formål såsom kvotebytning med andre lande og nyetablering af fiskere. En mindre del af de samlede danske kvoter inden for det pelagiske fiskeri holdes således uden for det individuelt omsættelige kvotesystem. Desuden er bagatelfiskeri tilladt uden besiddelse af individuelt omsættelige kvoter. De individuelle kvoteandele er offentliggjort på Fiskeridirektoratets hjemmeside. Der eksisterer et løbende opsigelsesvarsel for kvoteandelene på 8 år.

Før indførelsen af det individuelt omsættelige kvotesystem foregik det pelagiske fiskeri som fiskeri på basis af rationer eller årsmængder. Disse adskiller sig ved længden af den periode, hvorunder kvoten er til rådighed. Ved rationsfiskeri tildeltes kvoten for en kortere periode, så som en måned, fjorten dage eller en uge. Kvoten kunne ændres fra periode til periode afhængig af fiskeriets udvikling. Ved fiskeri på basis af årsmængder tildeltes hvert fartøj en kvote for et år ad gangen. Årsmængderne anvendtes i sildeog makrelfiskeriet.

Benyttelsen af lukkede områder indgår også i forvaltningen af det danske fiskeri. I de danske farvande er der lukket for enhver form for fiskeri i Bornholmerdybet, samt i to andre områder i Østersøen i perioden fra den 1. maj til og med den 31. oktober. Forbuddene gælder dog ikke laksefiskeriet. Tilsvarende er der fra starten af 2009 lukket for fiskeri i dele af Kattegat og nordlige del af Øresund nogle måneder i starten af året for særligt at skåne torskebestandene. Restriktionerne på fiskeriet findes endvidere i form af de såkaldte „kasser“; tobiskassen ved den skotske østkyst, brislingekassen og rødspættekassen i Nordsøen, sperlingkassen samt Shetlandskassen, som indebærer, at fiskeriet enten er lukket eller begrænset i disse områder. En ny ordning med tidsbegrænsede lukninger, der ikke tidligere har været benyttet i danske fiskeri, påbegyndtes i 2009 i Nordsøen og Skagerrak, hvor der konstateres store koncentrationer af ungfisk af torsk, kuller, mørksej eller hvilling. Lukningerne gælder dog kun fiskeri med redskaber rettet mod disse arter. For tobis gælder generelt, at der ikke må fiskes før 1. april.

Endelig findes en række tekniske bevaringsforanstaltninger. Således er de tilladte mindstemål for sild fastsat til $20 \mathrm{~cm}$ i Nordsøen og $18 \mathrm{~cm}$ i Kattegat og Skagerrak samt for makrel hhv. $30 \mathrm{~cm}$ og $20 \mathrm{~cm}$ i de to forvaltningsområder. For industrifiskene er der ingen mindstemål med undtagelse af hestemakrel $(15 \mathrm{~cm})$. Der har siden 2002 været et forbud mod udsmid eller såkaldt discard af fisk, der kan landes lovligt, hvilket dog kan være vanskeligt at håndhæve. Discard er ikke så velundersøgt for det pelagiske fiskeri som for det demarsale fiskeri, men kan ligesom „slipping“, hvor fisk slippes, inden de er bragt om bord på fartøjet, i perioder forekomme i silde- og makrelfiskeriet. Der er desuden begrænsninger på maskestørrelsen i form af 
mindste maskevidder for de forskellige fiskerier. I forbindelse med industrifiskeri er der begrænsninger på, hvor stor bifangsten af sild og makrel må være. Der eksisterer endvidere bestemmelser for de minimalt acceptable andele af målarter samt for de maksimalt tilladte bifangster for de forskellige redskabstyper og intervaller af maskestørrelser i de enkelte regioner og geografiske områder baseret på EU direktiv 850/98.

Betydende ændringer af fiskeriforvaltningen.

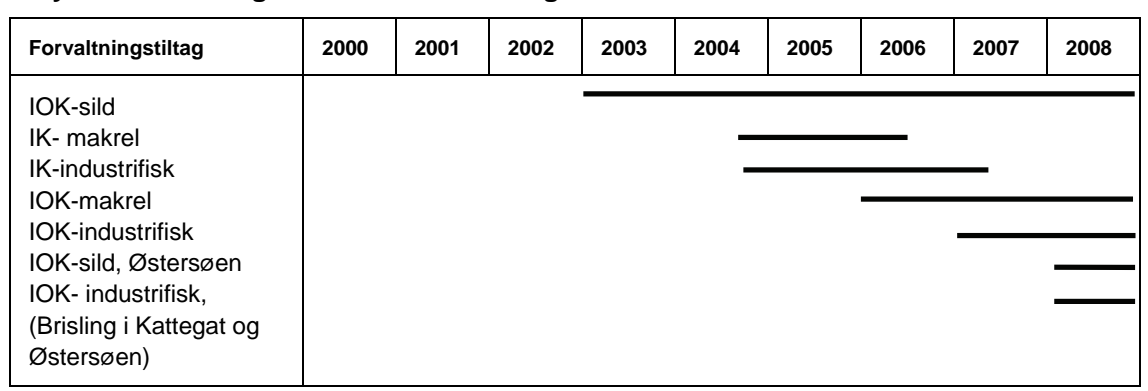

Anm.: Individuelt omsættelige kvoter forkortes IOK og individuelt ikke-omsættelige kvoter IK.

Forvaltningstiltag, der har eksisteret i uændret form gennem hele perioden, eller hvor kun mindre ændringer har fundet sted, er ikke anført i diagrammet. Det er den samlede vurdering, at det foruden kvote- og adgangsbegrænsninger, som begge har fungeret i en lang årrække, først og fremmest er indførelsen af det individuelt omsættelige kvotesystem, der har haft størst betydning for udviklingen i det pelagiske fiskeri i Danmark i den behandlede periode.

\section{B.2.5. Storbritannien}

\section{Fiskeriet}

Sild og især makrel er vigtige konsumarter for Storbritannien. Industrifiskeriet har kun mindre betydning i Storbritannien med blåhvilling som den eneste art, der fiskes i et vist omfang. Der fiskes sild især i Nordsøen samt desuden i farvandet vest for Skotland samt i Norskehavet. Makrel fiskes vest for Skotland, mens blåhvilling fiskes vest for de britiske øer.

\section{Forvaltningen}

De årlige kvoter er som de øvrige EU-lande et resultat af EUs samlede tilladte fangstmængde for arterne og det gældende faste kvotefordelingssystem mellem landene, samt fiskeriaftaler med landene udenfor EU, heriblandt Norge, Island og Færøerne. De britiske kvoter af sild i Nordsøen og farvandet vest for Skotland samt for makrel vest for Skotland er blevet reduceret for perioden 2007-2012 pga. af væsentlige overskridelse af disse kvoter i 2001-05. I den betragtede periode fra 2000 og frem har makrelkvoterne været relativt stabile. Silde- og blåhvillingkvoterne har været faldende de 
senere år. Fordelingen af de britiske kvoter til de enkelte fartøjer foregår som beskrevet nedenfor ved hjælp af et system med faste kvoteandele.

Siden slutningen af 1980'erne har der været et loft over fiskerikapaciteten. Alle fartøjer skal være registreret som erhvervsfiskerfartøj i det britiske register over fiskerfartøjer for at kunne drive fiskeri. Licensen angiver specifikke betingelser, som skal overholdes, når fiskeriet udføres, herunder angives de havområder, hvor fartøjet kan fiske og de arter, som fiskeriet kan rettes imod. For hvert fartøj er der på basis af dets størrelse (samlet længde og største bredde) samt motorkraft (kW) beregnet et antal kapacitetsenheder. Etablering af nye fartøjer med adgang til at drive fiskeri kan kun ske ved at opkøbe licens/kapacitet i eksisterende fartøjer. Ved overdragelse af en licens til et andet fartøj, eller hvis der aggregeres kapacitetsenheder fra flere mindre fartøjer i et større fartøj, vil mængden af kapacitetsenheder blive reduceret efter bestemte regler.

Som i de øvrige EU lande er der fra 2003 indført en indsatsforvaltning i form af en begrænsning i antal havdage for de enkelte fartøjer tildelt efter redskabskategorier og forvaltningsområder. Systemet overgik fra og med januar 2009 til en ny ordning, baseret på kilowattdage. Indsatsforvaltningen har ingen betydning for det pelagiske fiskeri.

Storbritannien indførte i 1999 et nyt system med faste kvoteandele. Tildelingerne af kvoteandele bygger på en referenceperiode dækkende fartøjernes fangster i treårsperioden 1994-96, dog er der for nogle arter af forskellige grunde valgt en anderledes referenceperiode. Før 1999 skete tildelingen ud fra rullende treårsperioder. Den årlige kvote i Storbritannien fordeles af myndighederne mellem de følgende tre grupperinger: a) fiskeriorganisationer på basis af deres medlemmers kvoteandele, som er knyttet til fartøjslicenserne, b) fartøjer uden for fiskeriorganisationerne samt c) fartøjer under 10 meter. Hovedparten af kvoterne fordeles videre til producentorganisationer, som så fordeler kvoterne til medlemmerne som individuelle kvoter. Producentorganisationerne har bemyndigelse til at fordele kvoter til medlemmer efter deres egne regler. De skal endvidere sikre, at de tildelte kvoter ikke overskrides. For de øvrige to grupperinger fastsættes reglerne for kvotetildelingen og dens udnyttelse af myndighederne på rationslignende vilkår, idet de enkelte fartøjer, der måtte have licenser til det pågældende fiskeri, tildeles bestemte mængder for afgrænsede perioder, i overvejende grad dog på månedsbasis. Myndighederne bestræber sig på at udstrække fiskeriet til hele året.

Det britiske kvoteadministrationssystem har ikke noget egentligt lovgrundlag, men bygger på en række ministerielle, administrative bestemmelser, hvorunder at kvoteandele årligt tildeles producentorganisationerne på baggrund af deres medlemsfartøjers fangster i ovennævnte referenceperioder. Fiskerne har således ikke ejerskab til kvoteenhederne, men de er dog på den anden side sikret $\mathrm{i}$ den administrative forordning imod skridt til at ændre væsentligt i reglerne uden konsultation af fiskerisektoren. De faste kvoteandele er knyttet til licenserne, og de kan normalt ikke skilles fra en aktiv licens. Kvoteandele overdrages derfor sammen med en licens, når denne over- 
føres, eller hvis der samles kapacitet i et større fartøj. De enkelte kvoteandele eller kvoteenheder har dog siden 2002 under visse betingelser kunnet skilles fra en licens og derpå overdrages til et andet fartøj. En sådan overdragelse skal godkendes af myndighederne.

Forvaltningen af kvoterne sker i producentorganisationerne, og disse har stor frihed til at forvalte kvoterne i overensstemmelse med deres medlemmers interesse, så længe de samlede kvoter overholdes. Producentorganisationerne kan således anvende et individuelt kvotesystem, samle kvoteenheder i puljer, samt desuden gøre brug af bytte eller leasing arrangementer for at få yderligere adgang til kvoteandele. Der skelnes mellem overførsel eller handel med kvoter, hvilket kan ske i løbet af året og som regel kun på årsbasis, og overførsel af kvoteandele sker på permanent basis. Den årlige handel og overførsel af kvoter er blevet foretaget mellem producentorganisationerne igennem mange år.

Restriktioner på fiskeriet findes i de lukkede områder, som indbefatter tobiskassen ved den skotske østkyst ved Wee banke samt i Shetlandskassen omkring Shetlands- og Orkneyøerne, hvori fiskeri er begrænset. Siden september 2007 har der eksisteret et system med real tids lukninger, „real time closures“, som et led i bestræbelserne på at genoprette torskebestanden i Nordsøen. Lukningerne foregår i perioder på 3 uger af gangen i områder, hvor der konstateres store koncentrationer af torsk. Lukningerne er således ikke rettet mod det pelagiske fiskeri og har derfor ikke nogen praktisk betydning for dette.

Bestemmelser om maskestørrelser og målarter følger den generelle EU forvaltning, dvs. EU's direktiv 850/98. Bifangst betragtes generelt set ikke som noget stort problem i det pelagiske fiskeri, ligesom discard heller ikke formodes at finde sted under normale omstændigheder.

\section{B.2.6. Rusland}

\section{Fiskeriet}

Rusland er et land med en lang fiskerihistorie. Som industri har det russiske fiskeri haft betydning siden den sidste del af 1800-tallet, da kystfiskeriet udgjorde en vigtig fødekilde. Efter den russiske revolution og introduktionen af planøkonomien blev strukturen af fiskeriet ændret. Myndighederne forvaltede fiskeriet, så det kunne bidrage med nok fisk til at dække efterspørgslen på hjemmemarkedet. Forvaltningen skete gennem industrialisering af den russiske fartøjsgruppe og derefter ved at implementere fartøjerne i store fiskerier i internationale farvande. Flådens målarter var bestande med stor biomasse som de pelagiske bestande. Det russiske fiskeri var under det sovjetiske styre opdelt i fem regioner. En regional enhed kaldet „Sevryba“ administrerede dette område og var ansvarlig for fødevareforsyningen af fisk. Den overordnede forvaltning for alle regionerne blev udført af den industri- 
elle brancheorganisation, som havde rollen som en „glavka“ - en kombination af et statsligt direktorat og en industriel aktør i regionen. I fiskeriindustrien var „Sevryba“ en ud af fem „glavki'“. Dets ansvarsområde var det op i to hovedgrupper:

- Fungere som en regional myndighed for fiskeriministeriet

- Koordinere og udføre økonomiske aktiviteter relateret til fiskeriindustrien i regionen (f. eks forskning, udvikling, produktionsteknologi, produktion og udbud, Nilssen 2010)

Ud fra dette ses, at „Sevryba“ på den ene side havde ansvaret for den regionale forvaltning af fiskeriressourcerne i det nordøstlige Atlanterhav, samt kvotefordelingen. På den anden side var „Sevryba“ også en overordnet aktør i alle forretningsfunktioner vedrørende fiskeriet i det nordvestlige Rusland. Som et eksempel var „Sevryba“ ansvarlig for beslutningen om, hvor og hvornår de forskellige bestande burde fanges (Nilssen 2010).

Gennem midten og sidste del af det 20. århundrede har flere hændelser påvirket den russiske fiskeriforvaltning. I 1991 blev Sovjetunionen opløst, og Rusland blev etableret. I overgangsperioden 1991-92 skete der en række store ændringer i fiskeindustrien i det nordvestlige Rusland. Opløsningen af Sovjetunionen samt introduktionen af en markedsstyret økonomi banede vejen for opløsningen af den sovjetiske styring af industrien som f.eks. „Sevryba“. Som et resultat heraf mistede den tidligere så magtfulde og store fiskerikoncern i det nordvestlige Rusland i praksis muligheden for at forvalte både forsknings- og udviklingsaktiviteter samt det kommercielle fiskeri ${ }^{9}$ (Nilssen 2010).

Et andet aspekt af ændringerne var den nye lovlige og økonomiske status for de tidligere „Sevryba“ fiskerivirksomheder. Generelt blev de tidligere statsejede fiskerivirksomheder og organisationer med få undtagelser omdannet til selvstændige virksomheder. Frigørelsen fra staten betød, at fiskerivirksomhederne pludselig havde fået frihed og kunne styre deres forretning/organisation efter egne mål og interesser.

Det historiske aspekt er vigtigt, da det har betydning for den russiske flåde i dag. Da de tidligere statsejede virksomheder blev gjort private, behøvede ejerne ikke at købe nye fartøjer, og den russiske flåde har derved ikke så store investeringsomkostninger som flåderne i andre lande. Da flåden blev bygget $\mathrm{i}$ sovjetperioden var brændstofeffektivitet ikke et problem, hvilket skinner igennem på brændstofomkostningerne i den nuværende russiske fartøjsgruppe. Det kræves at en vis andel af fangsten landes i Rusland til indenrigs forbrug, og der er en maksimal pris på disse landinger (Nilssen 2010).

I dag består den nordvestlige russiske flåde mest af forskellige typer af trawlere, hvilket står i kontrast til Norge, hvor f.eks. notfiskeri bruges i det pelagiske fiskeri. Målarterne er hovedsageligt norsk vårgydende sild, makrel, lodde, torsk og blåhvilling. En gruppe pelagiske trawlere af typen BMTR Pulkovskij Meridian er udvalgt til at repræsentere den russiske pela- 
giske fartøjsgruppe i denne rapport. Grundet sprogproblemer samt kulturelle forskelle har det ikke været muligt at indsamle de nødvendige data til at kunne lave den samme analyse som for de øvrige lande.

\section{Forvaltningen}

Når de årlige TAC'ere, kvotefordelinger og forvaltningsspørgsmål mellem de forskellige lande er fastlagt, bliver den nationale kvotefordeling i Rusland gennemført. I Rusland har man siden sovjetperioden haft et kvotesystem, hvor Statens Fiskeriudvalg fordeler kvoterne mellem virksomheder med licens. Med et kvotesystem som dette kan virksomhederne frit fordele deres kvoter på fartøjerne i deres fartøjsgruppe. Dette betyder f.eks., at en virksomhed med 10 fartøjer kan vælge at fiske hele kvoten med bare tre af fartøjerne (Nilssen 2010). I perioden fra 2000-2003 blev størstedelen af kvoterne fordelt på historisk baggrund (størrelsen af tidligere givne kvoter og fangster) og fangstkapacitet (Hønneland 2005), men en vis andel af kvoterne blev fordelt på en ny måde. Ved at bortaktionere en del at den totale kommercielle kvote håbede den russiske regering at opnå større åbenhed med hensyn til fordeling af kvoterne samt en stigning i det offentliges afkast fra fiskeriet. Det var dog et krav, at en given andel af de bortaktionerede kvoter landes i Rusland, samt at der var en maksimumspris på disse landinger (Nilssen 2010).

I 2003 blev kvotefordelingsmetoden ændret. Den russiske regering valgte at afskaffe aktionssystemet og i stedet introducerede en ressourceafgift (en afgift på kvoteandele) på alle arter. Den eneste undtagelse for dette nye system var de kommercielle mest vigtige bestande, som fortsat blev forvaltet under det gamle system (Hønneland 2005). Derudover blev det besluttet, at kvoterne skulle tildeles for en periode på fem år på baggrund af fangstkapaciteten for de seneste tre år.

Udover licens- og kvotesystemet har Rusland også nogle tekniske reguleringer. De tekniske reguleringer for norsk vårgydende sild og lodde i Barentshavet er vist i tabel B3.

Tabel B3: Oversigt over de forskellige tekniske reguleringsmekanismer for det industrielle fiskeri i den russiske EEZ for Barentshavet fra år 2009.

\begin{tabular}{llll}
\hline Fiskebestand & $\begin{array}{l}\text { Indre maskemål } \\
\text { (mm) }\end{array}$ & $\begin{array}{l}\text { Minimum fiske størrelse } \\
\text { (cm) }\end{array}$ & $\begin{array}{l}\text { Maksimum tilladt bifangst } \\
\text { (\%) }\end{array}$ \\
\hline Norsk vårgydende sild & 16 & 15 & 15 \\
Lodde i Barentshavet & 16 & 16 & $\begin{array}{l}10 \text { og } 300 \text { individer pr. tons } \\
\text { lodde af hver af arterne } \\
\text { under minimumstørrelsen; } \\
\text { torsk, kuller, sild, grøn- } \\
\text { landsk helleflynder og } \\
\text { norsk vårgydende sild }\end{array}$ \\
\hline
\end{tabular}

Kilde: Fiskeridirektoratet i Norge (b). 
${ }^{1}$ I denne rapport anvendes begrebet samfundsøkonomisk afkast, hvor andre undersøgelser anvender ressourcerente. Teoretisk består samfundsøkonomisk afkast af ressourcerente samt producentrente (inframarginal rente), hvor producentrenten er den rente, nogle fiskere får, fordi de er mere effektive til at fiske end andre. Den infra-marginale rente eksisterer i alle erhverv, ressourcerenten kun i erhverv der baserer sig på udnyttelse af naturressourcer, som eksempelvis fiskeri. I praksis er beregningen af det samfundsøkonomiske afkast i denne undersøgelse og ressourcerenten i tidligere undersøgelser baseret på samme metodiske grundlag.

${ }^{2}$ Blåhvilling er ikke en egentlig pelagisk fiskeart, men den medtages i undersøgelsen af de pelagiske fiskerier, da den primært fanges af fartøjer, der fisker efter pelagiske arter.

${ }^{3}$ Et grandfathering princip anvendt i fiskeriforvaltning indebærer, at fiskerirettigheder foræres til dem, der tidligere har haft adgang til fiskeri, og i et forhold der nogenlunde svarer til deres aktivitet. Fx ved en fordeling ud fra historiske fangster.

${ }^{4}$ Co-management indebærer, at den offentlige sektor (fiskeriforvaltningsmyndigheden) og fiskerisamfundene deler ansvaret for fiskeriforvaltningen.

${ }^{5}$ Årsagen til, at offentlige indtægter fra brugerbetaling er lagt til på højresiden i (2), er at brugerbetaling indgår som en del af fartøjsgruppens omkostninger. Dette skal neutraliseres.

${ }^{6}$ Antagelsen om, at indtægter fra fangst af ikke kvoterede fiskearter er konstant, kan være problematisk, da der kan være substitution mellem kvotebelagte og ikke kvotebelagte bestande. Antagelsen er imidlertid af mindre betydning i nærværende analyse, da de betragtede fartøjsgruppers omsætning fra ikke kvoterede fiskearter er beskeden.

${ }^{7}$ Omkostningskurven (med aflønning af kapital og arbejdskraft i alternativ anvendelse) kan også i visse situationer få andre former end den valgte. Således kan omkostningskurven (C i figur B4.1) få en omvendt Uform, såfremt forvaltningsomkostningerne inddrages, og disse samtidig opvejer øvrige omkostninger. Dette skal ses i sammenhæng med, at forvaltningsomkostningerne normalt vil være højere ved forvaltning end ved frit fiskeri, hvor de kan være nul. I nærværende artikel identificeres omkostningsfunktionen dog uden forvaltningsomkostninger, da det maksimale samfundsøkonomiske afkast alene identificeres for type A.

${ }^{8}$ At v $=0,33$ er et skøn. Skønnet er dog baseret på en approksimation foretaget på grundlag af en undersøgelse af faktiske forskelle i effektivitet i fiskeriet efter torsk i Nordsøen (Lindebo et al 2002). Fartøjers effektivitet måles ved en score baseret på „Data Envelopment Analysis“, som angiver, hvor mange produktionsfaktorer et givet fartøj bruger i forhold til det mest effektive.

${ }^{9}$ Under sovjetperioden blev de traditionelle fiskerivirksomheder tildelt en række andre opgaver uden for fiskerierhvervet, f.eks. opbygning og administration af skoler, hospitaler, hoteller og andre samfundsopgaver. Efter omstruktureringen af systemet beholdt virksomhederne deres eksterne opgaver trods de tydelige finansielle begrænsninger, det medførte. Det er interessant, at nogle af fiskerivirksomhederne er i en proces for reorganisering. F.eks. har den største traditionelle fiskerivirksomhed „Tralflot“ delt sig op i fire dele, hvor en del opererer med nye opgraderede fartøjer, mens en anden del opererer med de helt større fartøjer. Den mest sandsynlige forklaring på dette er, at virksomheden har behov for at isolere sine omkostninger og indtægter, samt at det er en måde at tilpasse virksomheden til det nye russiske skattesystem. 